ESNÉL JOSÉ FAGUNDES

RELAÇÕES PÚBLICAS NO COMPLEXO HOTELEIRO DA REGIÃO NORDESTE DO BRASIL: perspectiva de uma nova abrangência para o campo das relações públicas. 
ESNÉL JOSÉ FAGUNDES

\section{RELAÇÕES PÚBLICAS NO COMPLEXO HOTELEIRO DA REGIÃO NORDESTE DO BRASIL: perspectiva de uma nova abrangência para o campo das relações públicas.}

Tese apresentada junto ao Programa de Pós-Graduação em Ciências da Comunicação, Área de Concentração Interfaces Sociais da Comunicação, Linha de Pesquisa Políticas e Estratégias de Comunicação da Escola de Comunicações e Artes da Universidade de São Paulo, como exigência parcial para a obtenção do título de Doutor em Ciências da Comunicação, sob a orientação do professor Doutor Waldir Ferreira. 


\section{RELAÇÕES PÚBLICAS NO COMPLEXO HOTELEIRO DA REGIÃO NORDESTE DO BRASIL: perspectiva de uma nova abrangência para o campo das relações públicas.}

Aprovado em

Tese apresentada junto ao Programa de Pós-Graduação em Ciências da Comunicação, Área de Concentração Interfaces Sociais da Comunicação, Linha de Pesquisa Políticas e Estratégias de Comunicação da Escola de Comunicações e Artes da Universidade de São Paulo, como exigência parcial para a obtenção do título de Doutor em Ciências da Comunicação, sob a orientação do professor Doutor Waldir Ferreira. 
Teimar e contestar obstinadamente são defeitos peculiares às almas vulgares. Ao passo que voltar atrás, corrigir-se, abandonar uma opinião errada no ardor da discussão são qualidades raras das almas fortes e dos espíritos filosóficos.

Montaigne (1533-1592) 
DEDICATÓRIA

Para meus pais, Clara e Adelino, irmãos, cunhadas e sobrinhos, pelo apoio e incentivo de sempre. 


\section{AGRADECIMENTOS}

A Deus.

Ao Professor Doutor Waldir Ferreira, orientador pela competente condução do trabalho e incentivo.

Aos amigos, Silvio Rogério Rocha de Castro, Éllida Neiva Guedes, Nadja Maria Wine de Oliveira, Terezinha Andrade Leal, Maria Stella Thomazi (in memorian), companheiros de todas as horas que em gestos, palavras e atitudes estiveram presentes na realização deste trabalho.

Aos professores e funcionários do Programa de Pós-Graduação da Escola de Comunicações e Artes da Universidade de São Paulo, pelo pronto atendimento e pela competência.

Aos colegas e funcionários do Departamento de Comunicação da Universidade Federal do Maranhão, pelo apoio recebido. 


\section{RESUMO}

Propõe-se e enfatiza-se a inter-relação existente entre as áreas de relações públicas e turismo, com base em bibliografia consultada e em diagnóstico realizado no complexo hoteleiro do nordeste brasileiro. Enfatiza-se a importância das relações públicas para o desenvolvimento e sustentação dos públicos de interesse dos empreendimentos hoteleiros, bem como a importância das atividades de relações públicas para o correto relacionamento organizacional. Citam-se conceitos e definições de relações públicas e hotel, para embasamento da hipótese e objetivos. Realça-se a importância dos relacionamentos organizacionais, do turismo, da hotelaria e da hospitalidade para a sustentação da organização na sociedade globalizada. Elabora-se, executa-se e analisa-se uma pesquisa qualitativa com o objetivo de perceber se são desenvolvidas atividades de relações públicas nos hotéis da região Nordeste do Brasil. Propõe-se como devem ser desenvolvidas as atividades de relações públicas nos hotéis.

Palavras-Chave - Comunicação; Relações Públicas, Turismo, Hotelaria; Relacionamento. 


\begin{abstract}
This study porposes and emphasizes the existing relationship between public relations and tourism, based on bibliography and a diagnostic done on a chain of northeastern Brazilian hotels. The importance of public relations in the development and support of the interested public of hotel enterprises, is emphasized, as is the importance of public relations activities for a positive organizational relationship. Hypotheses and objectives based on concepts and definitions of public relations and tourism have been quoted. The importance of organizational relationships of tourism, the hotel business and hospitality as far as organizational support in globalised society is concerned, is hereby enlanced. This qualitative research has been developed, executed and analised with the objective to create awareness in the case of activities developed by the public relations sector in hotels in the Northeastern regions of Brazil. Proposals on how activities by public relations in hotels should be developed are hereby presented
\end{abstract}

Key words - Communication; Public Relations; Tourism; Hotel Business; Relationship. 


\section{LISTA DE FIGURAS}

Figura 1 - Interseção entre turismo e hospitalidade e estabelecimento de itens para

Análise 105

Figura 2 - Modelo Organizacional SPARSE - Integração Gerencial na Nova Era 108

\section{LISTA DE QUADROS}

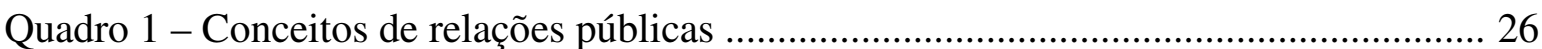

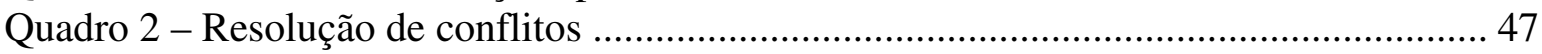

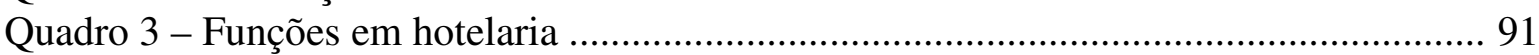

Quadro 4 - Dimensões dos Relacionamentos Interpessoais ............................................... 110 


\section{SUMÁRIO}

INTRODUÇÃ

CAPÍTULO I - QUADRO TEÓRICO DE REFERÊNCIA............................................06

CAPÍTULO II - PERCURSO METODOLÓGICO.........................................................31

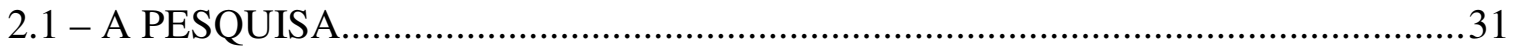

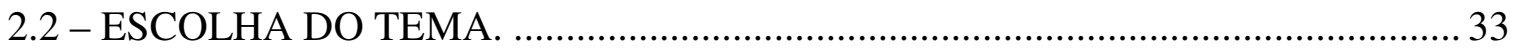

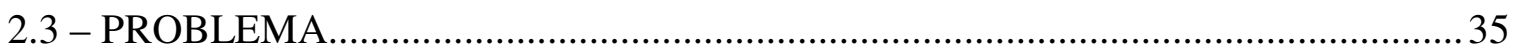

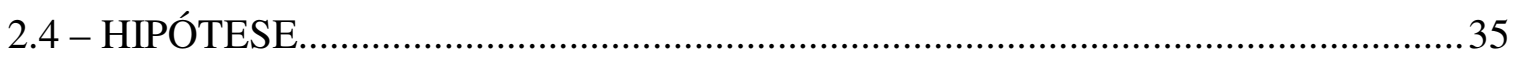

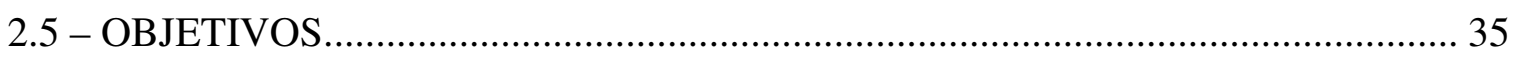

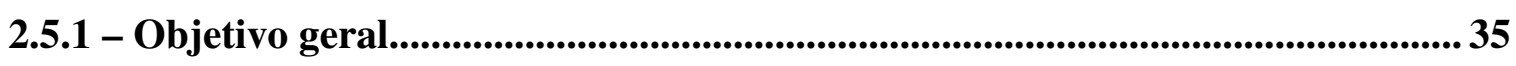

2.5.2 - Objetivos específicos............................................................................................. 35

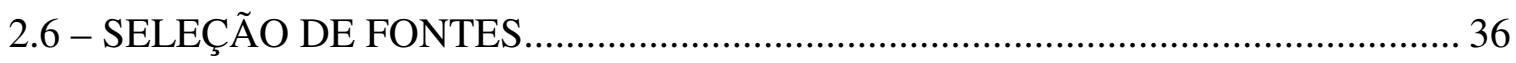

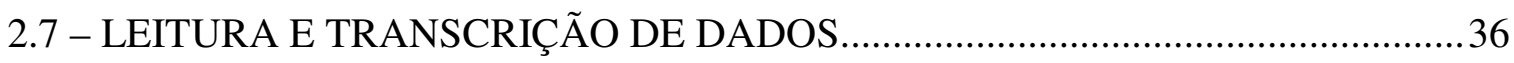

2.8 - ALGUNS PRESSUPOSTOS METODOLÓGICOS............................................... 36

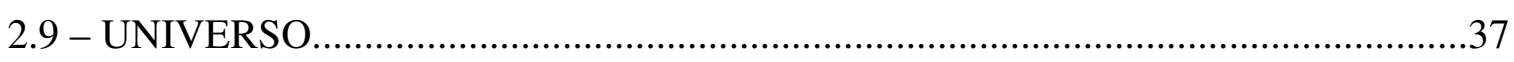

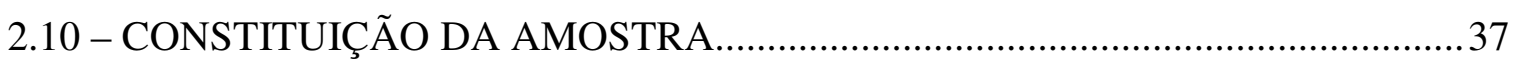

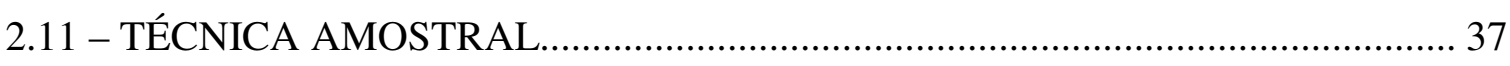

2.12 - ELABORAÇÃO DO INSTRUMENTO DA PESQUISA....................................... 38

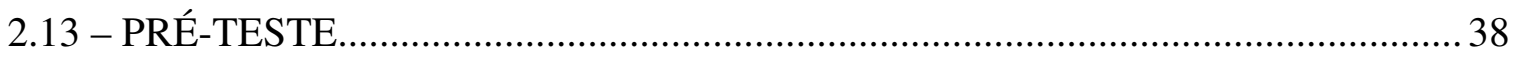

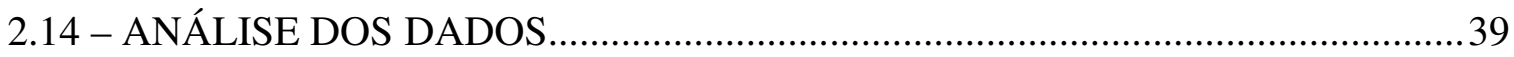

\section{CAPÍTULO III - RELACIONAMENTOS ESTRATÉGICOS /}

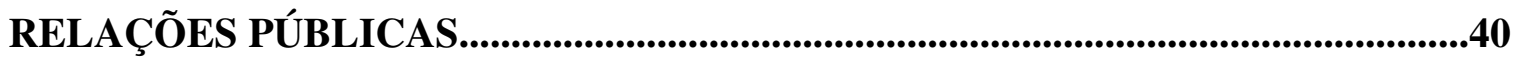

3.1 - FUNÇÕES E ATIVIDADES DE RELAÇÕES PÚBLICAS................................... 40

3.2 - RELACIONAMENTO ORGANIZAÇÃO-PÚBLICOS......................................... 44

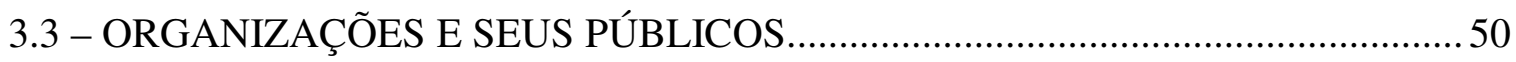

3.4 - A IMPORTÂNCIA DAS RELAÇÕES PÚBLICAS NA SOCIEDADE

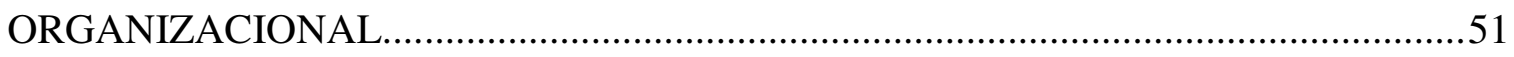

3.5 - FUNÇÕES E ATIVIDADES DE RELAÇÕES PÚBLICAS ....................................52

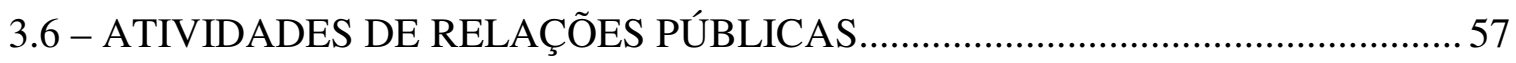


CAPITULO IV - TURISMO E TURISTA NO BRASIL:

PEQUENO RETRATO....................................................................................................6 61

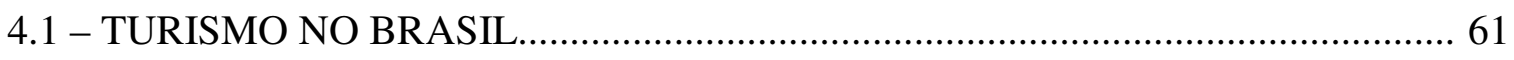

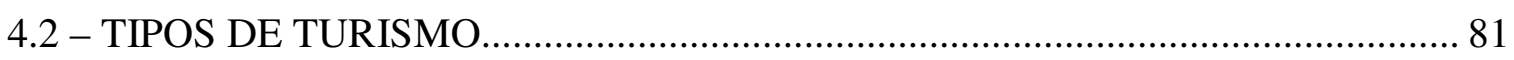

CAPÍTULO V - HOTELARIA, TURISMO E HOSPITALIDADE:

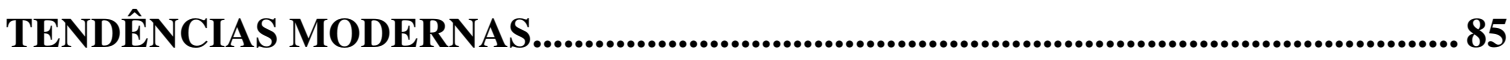

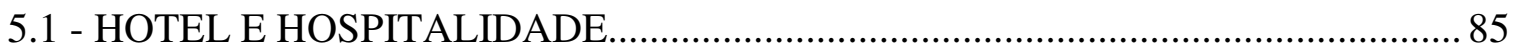

CAPÍTULO VI - RELAÇÕES PÚBLICAS NA HOTELARIA:

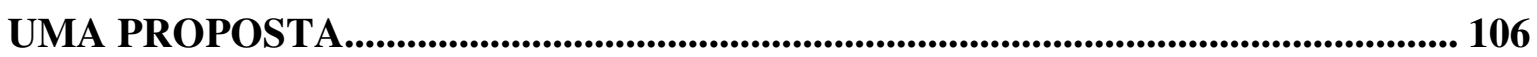

6.1 - PESQUISA COMO FUNÇÃO DE RELAÇÕES PÚBLICAS.................................. 112

6.2 - ASSESSORIA COMO FUNÇÃO DE RELAÇÕES PÚBLICAS............................ 113

6.3 - PLANEJAMENTO COMO FUNÇÃO DE RELAÇÕES PÚBLICAS...................... 114

6.4 - EXECUÇÃO COMO FUNÇÃO DE RELAÇÕES PÚBLICAS............................... 115

6.5 - AVALIAÇÃO COMO FUNÇÃO DE RELAÇÕES PÚBLICAS............................. 116

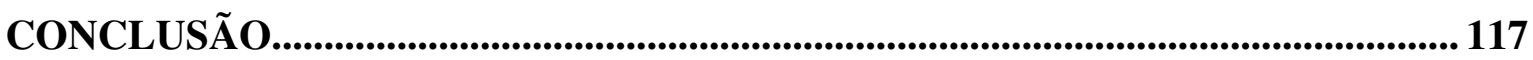

REFERÊNCIAS BIBLIOGRÁFICAS..........................................................................124

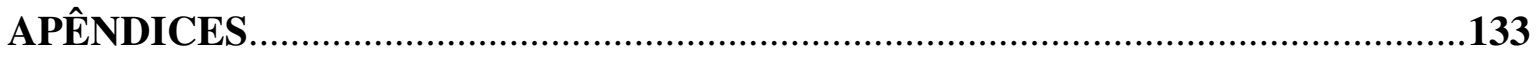

APÊNDICE A - MODELO DE PROTOCOLO............................................................... 134

APÊNDICE B - HOTÉIS PESQUISADOS...............................................................136 


\section{INTRODUÇÃO}

A presente pesquisa pretende esclarecer se existem e como são realizadas as atividades de relações públicas no complexo hoteleiro da região Nordeste do Brasil, numa tentativa de contribuição para o desenvolvimento do mercado de trabalho dos profissionais de relações públicas e, principalmente, analisar e avaliar as atividades no setor turismo/hotelaria. Trata-se, por certo, de uma longa trajetória a ser percorrida, considerando que o parque hoteleiro forma um complexo organizacional com características peculiares. Para atingir os objetivos propostos o estudo foi dividido em cinco capítulos de caráter teórico e um de caráter prático, além da conclusão.

Abordar assuntos relacionados às funções e conceitos de relações públicas desenvolvidos em atividades específicas, como neste caso o turismo/hotelaria, equivale enfrentar desafios acadêmicos consolidados e propor ao mesmo tempo paradigmas que sustentem os desafios contemporâneos da sociedade em relação ao desenvolvimento das relações públicas.

Esta pesquisa, eminentemente acadêmica, poderá resultar numa contribuição aos professores, profissionais e estudantes de relações públicas no sentido de conscientizá-los da necessidade de conhecer mais profundamente uma área em plena expansão e que, segundo organizações mundiais, estabeleceu-se para sempre na sociedade. Poderá também servir para que os profissionais do turismo e da hotelaria entendam a verdadeira função das relações públicas e o quanto esta atividade pode significar para o desenvolvimento e manutenção dos relacionamentos existentes entre o hotel e seus públicos de interesse.

Este estudo é uma tentativa de contribuição acadêmica que justifica-se pela necessidade de se conhecer áreas específicas para a atuação dos profissionais de relações públicas, diagnosticando-se dúvidas e deficiências nestas áreas com o propósito de elaborar procedimentos que colaborem para a eficiência e eficácia das atividades de relações públicas.

O percurso metodológico está baseado numa visão mais holística do processo de pesquisa social, com o objetivo de compreender e interpretar o comportamento, as atitudes e os padrões do entrevistado. Para tanto, utilizou-se a pesquisa descritivo-exploratória, por meio do método qualitativo que procurou conhecer a realidade, sem nela interferir ou modificá-la.

As entrevistas foram realizadas pessoalmente pelo investigador que procurou aplicar a técnica de ouvir, não emitindo opiniões.

O objetivo geral deste trabalho é, identificar, analisar e avaliar se as atividades de relações públicas estão acontecendo nos hotéis da região Nordeste do Brasil. Para tanto, 
recorreu-se a um considerável material bibliográfico, discutido e selecionado junto com o orientador, desenvolvido em bibliotecas públicas e particulares, sites de instituições oficiais e entidades associativas, que foi complementado com entrevistas em 27 hotéis, do Nordeste do Brasil, visitados pelo autor desta pesquisa.

Este é, pois, o objetivo desta tese, que traz como título "Relações públicas no complexo hoteleiro da região Nordeste do Brasil: perspectiva de uma nova abrangência para o campo das relações públicas", tendo como hipótese que o "mercado turístico/hoteleiro da região Nordeste do Brasil pode ser um espaço de atuação do profissional de relações públicas, por meio da implementação e conhecimento dessas atividades por parte dos gestores de turismo/hotelaria".

O primeiro capítulo objetiva entender os assuntos e os autores que servem de embasamento para a pesquisa, culminando com a consolidação de noções gerais de turismo, hotelaria, hospitalidade, relações públicas e relacionamento. Estes temas são abordados acreditando-se que tanto as relações públicas como o turismo/hotelaria têm neles a razão de suas atividades.

Vale ressaltar que não é objetivo do presente trabalho discorrer profundamente sobre relacionamentos, porém, achou-se necessário aprofundar-se um pouco no assunto para apontar como se processam os relacionamentos do homem com as instituições. Buscou-se compreender como acontecem os relacionamentos, por ser fundamental neste estudo, de modo a perceber a importância das relações públicas na sociedade moderna.

Assim, os estudos de Martin Buber, pensador contemporâneo, serviram de suporte para o entendimento do relacionamento, tendo seu ponto alto, a compreensão da ontologia na obra Eu e Tu (2004).

O capítulo dois procura demonstrar o caminho que foi seguido para a realização deste trabalho. Entende-se ser este o momento de explicitar a base utilizada para a escolha da metodologia proposta para esta pesquisa. Assim, objetivando evidenciar o entendimento do pensamento dos autores, acrescidos de idéias próprias e opiniões, demonstra-se ser importante para este estudo, partir da pesquisa bibliográfica, quando se realizou um planejamento global que incluiu a identificação, localização e obtenção da bibliografia pertinente sobre o assunto, para que se pudesse apresentar um texto sistematizado, a partir da literatura examinada. Assim, compreende-se que esta pesquisa deveria percorrer um caminho dividido em duas etapas distintas: a primeira diz respeito à revisão bibliográfica e a segunda à pesquisa de campo. Na pesquisa bibliográfica examinou-se a literatura sobre relações públicas, turismo, 
hospitalidade e hotelaria, enfocando as especificidades conceituais para se compreender a abrangência das duas áreas.

Como método principal, optou-se pela pesquisa qualitativa, o que se entende, não impossibilita a obtenção de dados quantitativos, uma vez que um método complementa o outro. A opção por este método de pesquisa se deu em face da natureza exploratória, descritiva e explanatória deste estudo, onde a pesquisa qualitativa oferece riqueza e profundidade necessárias para a compreensão dos significados que estão além dos dados coletados e que, na maioria das vezes, são possíveis somente por meio da pesquisa quantitativa.

O propósito da pesquisa foi verificar se os hotéis da região Nordeste do Brasil desenvolvem funções e atividades de relações públicas, por quem são desenvolvidas e se existe um setor responsável pela elaboração de políticas que sustentem e direcionem estas atividades. Foram identificados pontos positivos e negativos, problemas enfrentados para o desenvolvimento das atividades e para implantação de políticas de relações públicas.

Para responder a hipótese e atingir os objetivos propostos, esta pesquisa buscou informações nos hotéis localizados no litoral da região Nordeste do Brasil, de acordo com a classificação do Guia 4 Rodas, sugestão da Banca de Qualificação, preocupada com o conflito existente entre as formas de classificação atuais. O Guia Brasil, mais conhecido como Guia 4 Rodas, é uma publicação da Editora Abril, com 43 anos de existência e tiragem média de 20 mil exemplares em 2008.

Para as relações públicas, que possuem paradigmas consolidados sobre os seus conceitos, numa abordagem que é sempre um desafio, procurou-se entender, no terceiro capítulo, por meio de estudiosos renomados, as funções e atividades das relações públicas e reforçar o importante valor que a atividade representa para a sociedade e para a organização.

Discorre-se sobre a organização, sem o objetivo de aprofundar-se no estudo da sociedade e das organizações, e, sim, o de identificar o papel que as organizações ocupam dentro da sociedade moderna e sua relação com os públicos que interferem na sua existência. Deixa-se evidente a evolução dos conceitos e definições de relações públicas ocorridos com o passar do tempo e sua adaptação às necessidades da academia e do mercado. Porém, procurase confirmar que sua essência continua a mesma - o relacionamento das organizações com os seus públicos de interesse. Não houve o intuito de analisar os conceitos, uma vez que isto já foi realizado em muitos trabalhos, mas houve a necessidade de citá-los para embasamento da pesquisa. Busca-se não seguir uma linha específica de autores, nem analisar a fundo o que cada um defende, uma vez que se entende que autores como Margarida Kunsch, Roberto 
Porto Simões, James Grunig, entre outros, identificam e analisam em profundidade o papel que as relações públicas exercem na sociedade atual. Portanto, os estudos dos mesmos são bases neste trabalho.

No capítulo quatro, busca-se compreender a indústria do turismo no Brasil e qual o papel que o turista desempenha neste cenário. A compreensão do turismo no Brasil se dá por meio de estudos realizados por autores consagrados, mas também se procura compreender a posição oficial do Governo por meio de planos do Ministério do Turismo. Entende-se, desta forma, que uma visão oficial contribui para traçar os limites e a evolução do turismo brasileiro. O panorama do turismo no Brasil e as características do turista são identificados nesta parte da pesquisa. Tipos de turismo, tipos de turistas são aqui citados.

O capítulo cinco identifica o hotel como organização. Quais são suas peculiaridades, suas características, desde itens de infra-estrutura a tipos de atividades desenvolvidas. Passase pelo quadro de profissionais necessários pela estruturação de pessoal, até localização ideal para a construção de um empreendimento hoteleiro. A hospitalidade, sua história, evolução e seus tipos, com ênfase na hospitalidade comercial são aqui tratados. Busca-se entender a hospitalidade em tempos atuais, onde estudiosos de várias ciências procuram conceituá-la e defini-la, criando grandes controvérsias, que acabam demonstrando diversos estágios abrangendo aspectos sociais, políticos, filosóficos, culturais e econômicos.

Para esta pesquisa interessa a hospitalidade comercial, praticada por estruturas receptivas de turistas, porém, identifica-se a evolução e os demais tipos de hospitalidade, entendendo que, desta forma, as características de cada tipo contribuirão para o entendimento da hospitalidade comercial, objeto deste trabalho. Percebe-se ainda, neste capítulo, que a hospitalidade, num primeiro momento, refere-se ao ato de acolher, de prestar serviço a alguém, porém, uma análise mais profunda revela que a hospitalidade é um processo complexo, onde estão embutidas as relações sociais - o que implica perceber recortes específicos de antropologia, história, sociologia, economia, geografia, comunicação, arquitetura, urbanismo, planejamento ambiental etc.

No sexto e último capítulo, busca-se compreender como as relações públicas podem ser desenvolvidas nos empreendimentos hoteleiros. A partir do entendimento que, para este trabalho, as relações públicas são o gerenciamento estratégico da comunicação, com o objetivo de manter os relacionamentos existentes em uma organização, utilizou-se do protocolo proposto para a realização da pesquisa, procurando investigar como podem ser desenvolvidas as atividades de relações públicas nos hotéis. O protocolo tem como base as funções de pesquisa, planejamento, assessoria, execução e avaliação em relações públicas. 
Pretende-se mostrar que o profissional de relações públicas necessita idealizar uma rede de relacionamentos que permita à organização ultrapassar suas fronteiras e criar uma cadeia de valor que gere estratégias de negócios. Assim, o profissional de relações públicas deve estar apto a estabelecer, manter e gerenciar relacionamentos, por meio das estratégias de comunicação. A habilidade de gerenciamento dos relacionamentos por meio da comunicação é essencial para que ocorra a integração, a reciprocidade e a interdependência das partes que envolvem a organização e dos seus públicos de interesse.

Este trabalho não tem a pretensão de ser uma obra concluída e, sim, servir de marco indicativo e instigar novas pesquisas em áreas específicas, demonstrando que as relações públicas são necessárias em todos os segmentos da sociedade. Entende o autor, que pelo seu teor, esta tese, reveste-se de aspectos inéditos, sendo a pesquisa pioneira. Espera ainda o autor, que seu intento seja alcançado, contribuindo desta forma para que as relações públicas consolidem-se ainda mais como atividade imprescindível para o desenvolvimento sustentável da sociedade. 


\section{CAPÍTULO I - QUADRO TEÓRICO DE REFERÊNCIA}

O mundo contemporâneo está passando por transformações que ocasionam rupturas em suas organizações e exigem uma reestruturação de suas instituições para que possam sobreviver a estas mudanças. O sufocamento da autonomia individual e da criatividade dos integrantes das organizações fará sucumbir instituições que não se dispuserem a modificações constantes e a uma total flexibilidade.

Lipovetsky, estudioso dos tempos modernos, ao analisar a sociedade atual, menciona que:

a sociedade que se apresenta é aquela na qual as forças de oposição à
modernidade democrática, liberal e individualista não são mais estruturantes;
na qual periclitaram os grandes objetivos alternativos; na qual a
modernização não mais encontra resistências organizacionais e ideológicas
de fundo. Nem todos os elementos pré-modernos se volatizaram, mas
mesmo eles funcionam segundo uma lógica moderna, desinstitucionalizada,
sem regulação (2004, p.54).

E complementa que até as classes e as culturas de classes se toldam em benefício do princípio da individualidade autônoma. O estado recua, a religião e a família se privatizam, a sociedade de mercado se impõe: para disputa, resta apenas o culto à concorrência econômica e democrática, a ambição técnica, os direitos do indivíduo. Eleva-se uma segunda modernidade, desregulamentadora e globalizada, sem contrários, absolutamente moderna, alicerçando-se essencialmente em três axiomas constitutivos da própria modernidade anterior: o mercado, a eficiência técnica, o indivíduo. "Tínhamos uma modernidade limitada; agora, é chegado o tempo da modernidade consumada".

Deixa-se um mundo que era altamente previsível para um mundo que muda a todo instante. Redesenham-se os espaços sociais, onde surgem os paradoxos da globalização, e o indivíduo ocupa papel de destaque. A visão dos indivíduos é que dá a direção para as organizações.

Assim, o relacionamento das pessoas com o seu trabalho assume papel vital para as organizações e pode ser compreendido por meio das preocupações de cada indivíduo, onde se detectam fatores motivacionais, comportamento com a atividade, jogos humanos e relações interpessoais, que causam conflitos - tornando complexos os relacionamentos dos grupos com as organizações.

O termo "relação" (do latim relatium, part. pass. de refero, de re e fero, trazer) expressa a existência de possível semelhança entre duas coisas, que estejam ordenadas uma a 
outra. "O que caracteriza a relação é a referência ou a ordem de uma coisa ou outra", Mora (2000, p. 2498). E relatum é o ato de relatar, informar, noticiar, que tem por objetivo informar e criar vínculo entre pessoas, estabelecendo, portanto, uma relação de interdependência entre as partes.

Em seus estudos sobre relacionamento França (2002, p. 32), esclarece, a partir dos estudos de Ferrater, o termo relacionamento: "A relação é uma das categorias de Aristóteles, que define o relativo (ad aliud) como a referência de uma coisa a outra". Tomás de Aquino sintetiza a definição de Aristóteles dizendo que "a relação consiste unicamente na referência a outro". E na lógica aristotélica, a relação é considerada um predicamento e, nessa qualidade, é definida como a ordem de uma coisa para com a outra. A relação é, portanto, na sua essência o estar direcionado para algo, o referir-se a algo, o dizer respeito a alguma coisa (o habere ad, o refferri ad, o ad-aliquid, o respectus, o esse ad).

Para os dicionaristas, relacionamento é ato ou efeito de relacionar-(se); capacidade em maior ou menor grau de manter relacionamentos, de conviver bem com seus semelhantes. Ferreira, 1999; Larousse, 1999; Houaiss, 2001. Na acepção brasileira, Ferreira (1999, p. 1735), diz que relacionamento é ligação de amizade, afetiva, profissional, etc., condicionada por uma série de atitudes recíprocas: relação. Larousse, na acepção geral, discorre que relação é o conjunto de vínculos recíprocos entre pessoas que se encontram, se freqüentam, etc., conjunto de ligações ou associações oficiais entre grupos ou países; relacionar: estabelecer relação ou analogia entre coisas diferentes; ligar-se.

A complexidade das relações dos indivíduos com seus grupos (pessoas, organizações, instituições), seus valores e conflitos, são registradas por Barret, ao afirmar que:

quando os seres humanos apareceram na Terra, rapidamente aprenderam que suas chances de sobrevivência aumentariam de modo significativo se vivessem em grupos familiares maiores. Os homens caçavam, as mulheres colhiam frutos e criavam seus filhos. O clã sobrevivia trabalhando junto pelo bem comum. Partilhavam crenças e valores comuns (1998, p. 36).

Ressalta ainda que, devido ao aumento das populações, a sobrevivência do clã era ameaçada à medida que aumentava a competição por território. Para proteger suas terras, os clãs com culturas semelhantes se uniram em formas de tribos. O modo de vida tribal tornou-se forma dominante de identidade cultural. Pelo bem da sobrevivência, os sistemas de crenças e valores dos clãs se fundiram numa cultura tribal compartilhada. Uma íntima dependência se desenvolveu entre a segurança e a prosperidade da tribo. À medida que as tribos prosperaram e cresceram, a competição pela terra e pelos recursos aumentou. Irromperam guerras pela 
'posse' do território. A sobrevivência estava intimamente ligada ao acúmulo de terras. Aqueles com extensões de terras maiores e mais férteis tinham melhor chance de sobreviver.

Formaram-se exércitos para proteger as terras tribais e conquistar novos territórios. As tribos mais fortes subjugaram as tribos mais fracas, e começaram a viver juntas sob autoridade de um monarca. As nações começaram a se formar: fronteiras tribais por fronteiras constitucionais. A era das monarquias começava

Percebe-se aí a importância que as relações possuem para a sobrevivência do homem, a ponto de inúmeros pesquisadores buscarem analisar como os homens se relacionam entre si e com as instituições às quais estão ligados.

Não é objetivo de o presente trabalho discorrer profundamente sobre relacionamentos, porém, achou-se necessário apontar como se processam os relacionamentos do homem com as instituições. Entende-se que compreender como se processam os relacionamentos é fundamental neste estudo, de modo a perceber a importância das relações públicas na sociedade moderna. Assim, buscou-se em Martin Buber, pensador contemporâneo, fundamentação para o estudo do relacionamento, tendo seu ponto alto, a compreensão da ontologia na obra Eu e Tu (2004).

Zuben, professor-pesquisador da Faculdade de Educação da Universidade de Campinas, fez a tradução e a introdução da obra Eu e Tu, quando analisa o trabalho de Buber, mencionando que:

a reflexão inicial de Eu e Tu apresenta a palavra como sendo dialógica. A categoria primordial da dialogicidade da palavra é o 'entre'. Mais do que uma análise objetiva da estrutura lógica ou semântica da linguagem, o que faria da palavra um simples dado, Buber desenvolve uma verdadeira ontologia da palavra atribuindo a ela, como palavra falante, o sentido de portadora do ser (2004, p. 30).

E ressalta que é por meio dela que o homem se introduz na existência. Não é o homem que conduz a palavra, mas é ela que o mantém no ser. Para Buber a palavra proferida é uma atitude efetiva, eficaz e atualizadora do ser do homem. Ela é um ato do homem por meio do qual ele se faz homem e se situa no mundo com os outros. Alertando que a intenção de Buber é desvendar o sentido existencial da palavra que, pela intencionalidade que a anima, é o princípio ontológico do homem como ser dia-logal e dia-pessoal.

O fato primitivo para Buber é a relação. O escopo último é apresentar uma ontologia da existência humana, explicitando a existência dialógica ou a vida em diálogo. As principais 
categorias desta vida em diálogo são: palavra, relação, diálogo, reciprocidade como ação totalizadora, subjetividade, pessoa, responsabilidade, decisão-liberdade, inter-humano (ZUBEN, 2004, p. 30).

Buber considera que "o mundo como experiência diz respeito à palavra-princípio EuIsso. A palavra-princípio Eu-Tu fundamenta o mundo da relação" (2004, p. 55). Assim, como base da relação três esferas, ele assinala:

O mundo da relação se realiza em três esferas. A primeira é a vida com a natureza. Nesta esfera a relação realiza-se numa penumbra como aquém da linguagem. As criaturas movem-se diante de nós sem possibilidade de vir até nós e o Tu que lhes endereçamos deparase com o limiar da palavra. A segunda é a vida dos homens. Nesta esfera a relação é manifesta e explícita: podemos endereçar e receber o Tu. A terceira é a vida com os seres espirituais. Aí a relação, ainda que envolta em nuvens, se revela, silenciosa, mas gerando a linguagem. Nós proferimos de todo nosso ser, a palavra-princípio sem que nossos lábios possam pronunciá-la. Entende-se, desta forma, que a relação de maior valor neste estudo é a localizada na segunda esfera, sem desvalorizar as demais. A sociedade moderna é feita de relacionamentos. As organizações procuram um bom relacionamento com seus públicos para sua sustentação no mercado. Porém, para França (2004, p. 100), existem duas situações claras onde o relacionamento organização-público sustenta-se por interesses institucionais: “(a) a capacidade de relacionamentos e de realização de negócios lucrativos para ambas as partes (relação de troca); b) no campo da opinião a possibilidade da criação de um 'clima' favorável à empresa pela qualidade operacional que reflete a identidade corporativa". Acrescentando que a existência desse 'clima de negócios' resulta da qualidade dos relacionamentos e, em suma, do planejamento estratégico, da identidade corporativa, dos valores e princípios operacionais e éticos da empresa.

Neste contexto, onde a reciprocidade de relação é a lei, os relacionamentos localizam-se no campo das relações sociais; os mesmos acontecem entre partes (organizações/organizações; organizações/públicos; públicos/organizações) que estão estabelecidas e legitimadas pela sociedade. James Grunig se utilizou do conceito de relacionamentos, simétricos e assimétricos, para defender sua posição sobre relações públicas. Para as relações públicas, os relacionamentos devem ser analisados a cada nova situação, uma vez que os mesmo são efêmeros, positivos ou negativos, duráveis ou não.

Marlene Marchiori (2006) ressalta que os relacionamentos nas organizações estão sofrendo mudanças com uma velocidade jamais vista em toda a história e que as respostas das organizações devem ser rápidas e versáteis, no mesmo ritmo. Conclui que é preciso que os 
profissionais estejam acompanhando cada situação para que tomem as decisões no momento mais oportuno e estejam preparados para responder a elas simultaneamente.

A literatura sobre a organização e o indivíduo demonstra que desde que se instituiu a prestação de um serviço em troca de um salário, o emprego, a própria sociedade dividiu a vida das pessoas em trabalho e lazer. O sucesso das pessoas está ligado ao seu profissional, embora muitos saibam e acreditem que seus valores mais importantes estão fora do ambiente de trabalho. Na contemporaneidade, vive-se numa sociedade organizacional que permite e impõe a proliferação de organizações estatais, privadas, religiosas, não-governamentais, recreativas e outras. Nelas, o homem contemporâneo despende a maior parte do seu tempo útil e depende delas para satisfazer parte de suas necessidades - o que ocasiona o surgimento da indústria do lazer, que se apodera do tempo livre do homem e oferece ao mesmo não apenas satisfação, mas também cria, se necessário, novas expectativas e desejos.

Krippendorf (2001, p. 16), ressalta que se não existisse o turismo, cúmplice da evasão, seria necessário construir clínicas e sanatórios, para que o ser humano se recuperasse do cansaço. Assim, o turismo funciona como uma válvula de escape, que mantém a sociedade funcionando. Entende-se, pois, por lazer, não mais o simples ócio, que os romanos opunham às atividades de trabalho, mas sim uma ação cultural, uma oportunidade de desenvolvimento pessoal e social. Lazer é um tempo precioso onde as alternativas de ação e participação de algumas atividades pode ser escolhida com mais liberdade. É o tempo que o homem tem para escolher o que fazer. Necessário ressaltar que qualquer escolha do indivíduo vem carregada de determinismos sociais, culturais, políticos e econômicos.

Quase sempre enfocado de forma restrita, como arte, esporte e entretenimento, o lazer surge como uma expressão da sociedade de consumo, que necessita dele para se reproduzir ideológica e materialmente. Dumazedier, diz que lazer é

o conjunto de ocupações às quais os indivíduos podem entregar-se de livre vontade, seja para repousar, divertir-se, recrear-se e entreter-se e/ou para desenvolver sua formação e informação desinteressada, sua livre capacidade criadora, após livrar-se ou desembaraçar-se das obrigações profissionais, familiares e sociais (DUMAZEDIER, 1994, p. 34).

A própria origem da palavra lazer (do latin, licere), significa ser lícito, é a ocupação não obrigatória de livre escolha do indivíduo, diferente de tempo livre onde estão incluídas as atividades de engajamento sócio-espiritual (religião), atividades de engajamento sóciopolítico (política). Para Weber, tempo livre é: 
o conjunto de períodos de tempo da vida de um indivíduo em que a pessoa se sente livre de determinações externas, sobretudo na forma de trabalho assalariado, ficando com ele livre para usar com sentido tais momentos, de tal forma que seja possível levar uma vida verdadeiramente humana (1969, p. 8)

Desta forma, entende-se que tempo livre e lazer são fundamentalmente diferentes, uma vez que o tempo livre pode ser preenchido com outra atividade que não seja o lazer.

Sêneca (2007, p. 29) discorre que a maioria dos homens não sabe empregar bem o tempo, deixando-o escapar.

Acredita-me, as coisas se passam exatamente como estou dizendo: alguns momentos são arrancados, outros escamoteados, outros mais nos escorrem pelos dedos. Todavia, a perda mais escandalosa é a que sofremos devido à nossa negligência. Se prestares bastante atenção, verás que passamos a maior parte da vida fazendo as coisas mal, uma boa parte sem fazer nada, e toda a nossa vida fazendo algo distinto do necessário. Cita-me um homem que saiba dar ao tempo o seu prêmio, reconhecer o valor de um dia, compreender que morre a cada dia.

Acerenza (1991, p. 31), divide o tempo livre que o homem dispõe em três categorias: a) tempo livre após o trabalho: obviamente é muito difícil uma pessoa dedicar seu tempo livre, após o trabalho, para fazer turismo, pois este exige um deslocamento e uma permanência fora de seu lugar habitual de residência. No entanto, nada impede que esta mesma pessoa possa desfrutar de seu tempo livre através de distrações, entretenimentos e/ou atividades para aumentar seu conhecimento, como assistir televisão, ir ao cinema, teatro e concertos, ouvir música, praticar algum tipo de esporte, dedicar-se à leitura ou às outras atividades; b) tempo livre de fim de semana: pode-se optar entre a recreação (clubes e parques) e o turismo (viagem a uma segunda residência no campo ou na praia, hotéis, camping, etc.); c) tempo livre de férias: pode-se dedicar entre outras atividades, à prática do turismo. O consumo do lazer em viagem é uma maneira de escapar, temporariamente, às agressões das urbes industriais, como também ampliar o, "horizonte" de conhecimento. Portanto, o turismo pode ser caracterizado como uma das expressões de que possuem um tempo livre de duração prolongada.

Diante disso, torna-se importante conceituar turismo. Busca-se em Coriolano, o conceito de turismo.

Uma forma mais elitizada de lazer, uma modalidade do uso do tempo livre que exige viagens, deslocamentos; uma infra-estrutura urbana e de serviços, transportes e hotéis. O turismo é para alguns um modo de vida e uma dinâmica social. A sociedade de consumo, entendendo a importância do 
lazer na contemporaneidade, transforma-o em turismo, passando a comercializá-lo nos moldes dessa sociedade, ou seja, atrelado às leis de mercado. O turismo é, pois, esta complexa atividade humana, e pode ser caracterizado como uma das maiores seduções dos tempos modernos, envolvendo um conjunto muito grande de relações, influências, motivações, desejos e representações (CORIOLANO, 1998, p. 28).

Estimulado pela globalização e pelas atuais conjunturas relativas ao modo de vida nas grandes cidades, o turismo figura entre as atividades econômicas de maior rentabilidade na sociedade atual, sempre fabricando ilusões, estilos de vida; é o hábito de viajar para descanso que está cada vez mais arraigado na vida do homem. Toda esta complexidade do turismo cria um mercado de serviços e produtos que geram milhões de empregos em todo o mundo.

Entende-se por serviços turísticos os meios de hospedagens (pousadas, hotéis, pensões, acampamentos, motéis), os serviços ligados à alimentação (restaurantes, bares, barracas de praias e similares), serviços de entretenimento (parques, casas de espetáculos, cinemas, teatros etc.), serviços de apoio (operadoras, agências de viagens, transportadoras, postos de informações, locadoras de veículos e outros).

Vários também são os fatores que influenciam a demanda turística, dentre eles destacam-se a geração, distribuição e apropriação de renda; o poder dos meios de comunicação de massa; e a propaganda aliada às grandes operadoras que atuam como fabricantes de sonhos. O turismo tornou-se um fenômeno, transformando-se assim num dos temas mais estudados pelas áreas sociais, econômicas e políticas, gerando abordagens diversificadas. Uma destas abordagens, a geográfica, defende que o turismo se desenvolve tanto na medida macro, nacional e internacional, como na dimensão micro, espaço urbano e rural local. O turismo utiliza os espaços geográficos como atrativo e os equipamentos urbanos como infra-estrutura.

À medida que uma localidade turística decide preservar suas áreas naturais, seus monumentos históricos e arqueológicos, como atrativo turístico, o desenvolvimento da preservação do meio ambiente se torna vital para esta localidade. Assim, pode-se afirmar que o turismo colabora para a conscientização dos moradores de localidades turísticas, os autóctones, sobre a preservação ambiental. Outro papel importante da atividade turística para a localidade é o impacto sociocultural, tanto no turista quanto nos moradores locais, estimulando assim uma maior integração entre povos de culturas diferentes. Sendo o turismo um produto cujo consumo só pode se dar no local, os lugares turísticos com melhor infra- 
estrutura e melhor qualidade de vida da população residente são, na verdade, os mais difundidos pelos veículos e instrumentos de comunicação turística.

Coriolano (1998, p. 145), ao analisar o local turístico destaca:

\begin{abstract}
A principal atração turística de um lugar vem sendo cada vez mais a qualidade de vida da população do lugar visitado. Qualidade de vida referese a condições e nível de vida da população e às condições técnicas do lugar. O primeiro aspecto está relacionado ao ser e o segundo, ao ter. Para um turismo de qualidade não basta o lugar oferecer infra-estrutura; implica também a qualidade do lugar que vai das condições ambientais às condições políticas, sociais e culturais de seus habitantes.
\end{abstract}

A expansão do turismo ocasionou a necessidade do desenvolvimento de vários setores como hospedagem, transporte (aéreo, terrestre e marítimo), alimentação, eventos etc., obrigando os mesmos a uma modernização em termos de estrutura física e às formas de gerenciamento. Quanto à hospedagem, um dos objetos desta pesquisa, é importante registrar que é uma atividade tão antiga quanto às primeiras viagens que se tem conhecimento.

Ao longo de sua história, a indústria hoteleira e, conseqüientemente, os serviços de hospedagem, passaram por constantes mudanças exigidas pela modernização da sociedade e pela demanda do mercado, que acabaram por influenciar o conceito de hospedagem, suas formas, tipicidade, padrões e outras variáveis.

Especificamente no Brasil, universo deste trabalho, segundo dados do Ministério do Turismo e da Associação Brasileira da Indústria Hoteleira (ABIH), a tecnologia foi, na última década, a protagonista destas mudanças. Percebe-se de forma clara e transparente que os meios de hospedagem, em constantes buscas pela qualidade, utilizam-se das inovações tecnológicas, para questões relativas ao atendimento, otimização e redução de custos, agilidade nos processos de check-in e check-out, chaves eletrônicas, duchas, elevadores e iluminação inteligentes, entre outros. A inovação não se deu apenas na infra-estrutura física; os serviços avançaram: saunas, massagens, fitness, business centers são hoje indispensáveis para a comodidade do hóspede.

O parque hoteleiro nacional, segundo a $\mathrm{ABIH}$, é composto, aproximadamente, por 25 mil meios de hospedagem, sendo 18 mil hotéis e pousadas, gerando mais de 550 mil empregos diretos e outros 500 mil indiretos, uma oferta de aproximadamente um milhão de apartamentos em todo o país e um faturamento de US\$ 2 bilhões ao ano.

Numa pesquisa, realizada em 2006, pela Fundação Instituto de Pesquisa da Universidade de São Paulo (FIPE), foram levantados dados relevantes para a compreensão da 
importância do setor hoteleiro no Brasil. Nessa pesquisa, em termos regionais, dois pontos merecem destaque: um sobre a região sudeste, que produz os insumos necessários para a hospedagem e, o segundo, refere-se ao desempenho da região Nordeste que gera relativamente mais riquezas, empregando relativamente menos pessoas, o que, mais uma vez, lhe confere um papel relevante no processo de crescimento regional, uma vez que estes resultados sugerem maior produtividade média da mão-de-obra ocupada na cadeia do setor.

A FIPE estimou que a quantidade de bens duráveis seja, em média, de 68 tipos diferentes de equipamentos, e a reposição dos mesmos é feita na mesma velocidade em empreendimentos de grande e pequeno porte. Constatou-se ainda, que o setor compra 100 mil televisores e 1, 6 milhão de lençóis ao ano.

Dentre as mudanças ocorridas, talvez a mais importante e complexa seja a mudança da terminologia hospedagem para hospitalidade. A indústria hoteleira começa perceber que muito mais que oferecer conforto, tecnologia, qualidade de serviços e boa estrutura, a integração do hóspede ao ambiente no qual ele se encontra é fator fundamental para sua fidelização e bem-estar. Entende-se que esta mudança não necessita apenas de investimento financeiro e, sim, de uma revisão da cultura existente na hotelaria nacional, que provoca um rompimento de paradigmas e costumes.

Vive-se a hospitalidade normalmente com os semelhantes, com as pessoas próximas, que compartilham os mesmos lugares, os mesmos costumes, a mesma cultura, a mesma religião. Mais difícil, porém, é a hospitalidade com os diferentes e distantes. Na sociedade globalizada, porém, segundo Boff (2005, p.163), “os impasses contemporâneos à hospitalidade são de grande monta". Sequer sabemos exatamente como enfrentar de forma hospitaleira os graves problemas mundiais das migrações, especialmente por motivos de guerra ou de crise econômica e da mobilidade natural entre povos e culturas. Nem por isso devemos renunciar ao ideal da hospitalidade que está na base de nossa humanidade e da convivência civilizada. Sem ela regrediríamos à sociedade selvagem dos lobos, ao que é chamado de 'estado natural'.

Compreende-se que hospitalidade não é um simples ato de receber, de dar abrigo e comida, é muito mais complexo, envolve serviços, estruturas e atitudes. O entendimento reducionista entre hospitalidade e hotelaria deve ser descartado, considerando o tema com a amplitude necessária para entender sua complexidade. Assim, análises de caráter epistemológico, histórico e empírico são necessárias para sua compreensão. Buscam-se em vários autores estas análises. 
Em Dias (2003, p. 97), encontra-se a origem da palavra hospitalidade: A noção de hospitalidade provém da palavra latina hospitalitas-atis e traduz-se como: o ato de acolher, hospedar; a qualidade do hospitaleiro; boa acolhida; recepção; tratamento afável, cortês, amabilidade; gentileza. Já a palavra hospes-itus se traduz por hóspede, forasteiro, estrangeiro, aquele que recebe ou o que é acolhido com hospitalidade; o indivíduo que se acomoda ou se acolhe provisoriamente em casa alheia, hotel ou outro meio de hospedagem; estranho. As palavras hospício (do latim hospitium-i, lugar em que viajantes podiam obter alimento e repouso temporariamente) e hospital (também do latim hospitale-icum, hospedaria ou casa de hóspede) eram correntes na Europa a partir do século XI e serviam para designar locais, à margem das antigas estradas romanas, destinados a abrigar peregrinos (muitos eram estabelecidos anexos a mosteiros), oferecendo assistência variada, inclusive tratamentos médicos. Nessa época eram utilizados para abrigar pessoas em viagem, doentes, loucos, sãos ou pobres, indiscriminadamente.

O professor Camargo (2004, p. 31), considera as noções de hospitalidade como um conjunto de 'leis não escritas' que regulam o ritual social. Com base nos estudos de Allain Caillé, que defende ser o dar-receber-retribuir um fato social e um paradigma científico inserido no contexto socioantropológico, propõe-se, para efeito didático, o desmembramento do dar-receber-retribuir, nas seguintes leis, aqui resumidas: 1 - a hospitalidade começa com uma dádiva; O que é dádiva? Utiliza-se a mesma a definição usada por Camargo, baseado nos estudo de Caillé (2002, p. 141): "é toda prestação de serviços ou de bens efetuada sem a garantia de retribuição, com o intuito de criar, manter ou reconstruir o vínculo social”. Mais do que o dom, a dádiva, o que importa é o vínculo social (a ser) criado. Convidar alguém para ir à sua casa, oferecer abrigo e comida a alguém em necessidade são dádivas expressas por gestos que se inserem dentro da dinâmica do dar -receber - retribuir. A dádiva desencadeia o processo de hospitalidade, seja ou não precedida de um convite ou de um pedido de ajuda, numa perspectiva de reforço do vínculo social; 2 - a dádiva implica sacrifícios. Oferecer uma dádiva ou hospitalidade é sacrificar algo que se tem em favor do donatário ou do hóspede. $\mathrm{O}$ anfitrião que diz 'desculpe-me, mas é tudo o que eu tenho para lhe oferecer', aceita implicitamente essa lei; 3 - toda dádiva traz implícito algum interesse. Quem dá algo sempre tem algum interesse. Mas isso não é tão fácil de entender. Esse interesse pode ser nobre, como ocorre na ajuda ao próximo em necessidade, um sentimento religioso ou simplesmente filantrópico. 4 - o dom deve ser recebido, aceito. Recusar um presente, uma honraria, uma lembrança, é algo que ainda soa insultuoso mesmo em nos dias atuais. Não aceitar a dádiva desencadeia o mecanismo oposto à hospitalidade, que é a hostilidade, palavra de mesma raiz 
etimológica. Não ir ao encontro da mão que nos é estendida é mais que recusar o vínculo social proposto. Significa agressão; 5 - receber implica aceitar uma situação de inferioridade diante do doador. A hospitalidade é sempre assimétrica. Receber algo de presente resulta na consciência de uma situação clara de desvantagem; 6 - quem recebe, deve retribuir. Retribuir é reinstaurar o dom, a dádiva. É reinstaurar o sacrifício, criar uma nova dádiva. Não obstante, o mais importante a se ressaltar é que a retribuição da dádiva não encerra o processo da hospitalidade humana. Ao contrário, neste sentido, a hospitalidade assume sua face mais nobre na moral humana, a de costurar, sedimentar e vivificar o tecido social e colocar em marcha esse processo sem fim que alimenta o vínculo humano. (CAMARGO 2004, p.19).

A complexidade do entendimento do que seja hospitalidade vem fazendo com que estudiosos do mundo todo se debrucem sobre o tema para compreender a abrangência e a importância da hospitalidade em seus vários aspectos. Em abril de 1997, pesquisadores e escritores sobre o assunto se reuniram em Nottingham e apresentaram idéias, as quais foram apresentadas em um documento. Este documento estimulou estudiosos do mundo inteiro a produzirem livros e artigos sobre hospitalidade. $\mathrm{O}$ documento apresenta hospitalidade como uma troca contemporânea, idealizada para aumentar a reciprocidade (bem estar) entre as partes envolvidas, por meio da oferta de alimentos e/ou bebidas e/ou acomodação.

Torna-se importante entender as funções básicas da hospitalidade para melhor compreender o seu papel dentro da sociedade globalizada. Assim em Selwin (2004, p. 26), encontram-se definidas estas funções:

\begin{abstract}
A função básica da hospitalidade é estabelecer um relacionamento ou promover um relacionamento já estabelecido. Os atos relacionados com a hospitalidade obtêm este resultado no processo de troca de produtos e serviços, tanto materiais quanto simbólicos, entre aqueles que dão hospitalidade (os anfitriões) e aqueles que a recebem (os hóspedes). Uma vez que os relacionamentos necessariamente se desenvolvem dentro de estruturas morais, uma das principais funções de qualquer ato de hospitalidade é (no caso de um relacionamento já existente) consolidar o reconhecimento de que os anfitriões e os hóspedes já partilham do mesmo universo moral ou (no caso de um novo relacionamento) permitir a construção de um universo moral em que tanto o anfitrião quanto o hóspede concordam em fazer parte.
\end{abstract}

Consolida-se, diante disso, a importância dos relacionamentos e a possibilidade da troca de experiências, valores culturais e morais e, principalmente, a importância do conhecimento das normas e regras de quem hospeda e de quem é hóspede. Só assim, dá-se a hospitalidade, com respeito mútuo dos valores morais do anfitrião e do hóspede. $\mathrm{O}$ respeito às 
diferentes práticas da hospitalidade em vários tipos de sociedades faz com que a definição seja ampliada e concebida em múltiplos aspectos e características.

Complementa-se esta visão com a ética da hospitalidade, encontrada em Camargo (2004, p. 31):

\begin{abstract}
Mais do que uma ética aplicada, dever-se-ia falar da hospitalidade e suas leis não escritas como uma ética em si mesma.

Essa expressão "não escrita" remete de imediato à idéia de que a hospitalidade é um processo de comunicação interpessoal, carregado de conteúdos não-verbais ou de conteúdos verbais que constituem fórmulas rituais que variam de grupo social para grupo social, mas que ao final são lidas apenas como desejo/recusa de vínculo humano. De que outra maneira entender as expressões "olá", "como vai?", "alô", "tudo bem" ou o mais econômico gesto de menear e abaixar a cabeça em reverência ao estranho?
\end{abstract}

Lashley (2004, p. 5), propõe uma definição ampla que permita ser a hospitalidade estudada e percebida, nos domínios social, privado e comercial: "colocando de um modo simples, cada domínio representa um aspecto da oferta de hospitalidade, que é tanto independente como sobreposto". Acrescentando que o domínio social da hospitalidade considera os cenários sociais em que a hospitalidade e os atos ligados à condição de hospitalidade ocorrem junto com os impactos de forças sociais sobre a produção e o consumo de alimentos, bebidas e acomodação; o domínio privado considera o âmbito das questões associadas à oferta da "trindade" no lar, assim como leva em consideração o impacto do relacionamento entre anfitrião e hóspede; o domínio comercial diz respeito à oferta de hospitalidade enquanto atividade econômica e inclui as atividades dos setores tanto privado quanto público.

Estudiosos como Gidra e Dias (2004, p. 122), defendem a definição de hospitalidade por meio de três requisitos fundamentais:

- Reconhecer e estudar a hospitalidade como um fenômeno psicossociocultural e não simplesmente como manifestação individual e de atitude de um anfitrião;

- Reconhecer sua complexidade como fenômeno humano, que se manifesta em múltiplos contextos e lugares, envolve múltiplas dimensões da realidade e ocorrem em meio a crises, instabilidades e mudanças sociais; cujo estudo, portanto, já não mais comporta os modelos clássicos de explicação e previsão da ciência positivista;

- Reconhecer a necessidade de estudar a hospitalidade com base em enfoques teóricos holísticos da sociedade e em uma visão interdisciplinar, que permitem contemplar em uma mesma leitura do fenômeno as dimensões da realidade tradicionalmente estudadas, de forma isolada e fragmentadas, pela psicologia social, sociologia e antropologia, entre outras ciências. 
Emprega-se hospitalidade em diferentes contextos como: doméstico, comercial, na esfera do Estado, legislação sobre estrangeiros e outros. A reflexão sobre a hospitalidade no turismo acontecerá no decorrer deste trabalho.

Entende-se ser, agora, o momento para compreensão de alguns pontos sobre o surgimento e o desenvolvimento da atividade hoteleira, prioritariamente, no Brasil. Estudiosos da área de hotelaria afirmam que não se sabe ao certo quando surgiu a atividade hoteleira no mundo, entretanto, supõe-se que a necessidade dos viajantes em procurar abrigo e alimentação durante as suas viagens tenha dado origem à atividade. Esta informação pode ser constatada em Campos e Gonçalves (2006, p. 71):

\begin{abstract}
A primeira notícia sobre a criação de um espaço destinado especificamente à hospedagem vem de alguns séculos antes da era cristã, quando na Grécia antiga, no santuário de Olímpia, eram realizados os jogos olímpicos. Para esses eventos, foram construídos o estádio e o pódio, onde se homenageavam os vencedores e ficava a chama olímpica. Mais tarde, foram acrescentados os balneários e uma hospedaria, com cerca de 10 mil metros quadrados, com o objetivo de abrigar os visitantes. Essa hospedaria teria sido o primeiro hotel de que se tem notícia.
\end{abstract}

Em Duarte (1996, p. 09), identifica-se como ocorreu a evolução da hotelaria, quando o mesmo destaca que no século VI a C. Já existia a demanda de hospedagem, em função do intercâmbio comercial entre as cidades européias da região mediterrânea. Os primeiros albergues operando de forma artesanal, não eram mais do que partes de residências ou mesmo quartos.

$\mathrm{Na}$ época do Império Romano existiam os hostellum, espécie de palacetes em que rei e nobres se hospedavam em suas viagens. No final da Idade Média, com o crescimento das cidades e o início da Revolução Mercantil, houve grande desenvolvimento das estalagens, que passaram a oferecer, além dos serviços de alojamento, refeições e vinhos, cocheiras e alimentação para os cavalos, troca de parelhas e serviços de manutenção e limpeza para as charretes ou outro tipo de veículo. É também neste período o costume de se identificar os estabelecimentos comerciais colocando-se adornos em sua entrada. $\mathrm{Na}$ França, as hospedarias usavam ramos verdes de cipreste ou tecidos em mastro nessa mesma cor. Na Inglaterra, colocava-se um mastro, bem alto, pintado na cor vermelha.

Na Inglaterra, no período de 1750 a 1820, no bojo da Revolução Industrial, as estalagens foram substituídas pelos inns, que conquistaram a reputação de serem os melhores hospedeiros daquela época. César Ritz, suíço, filho de camponeses, construiu em 1870 o 
primeiro estabelecimento hoteleiro em Paris, considerado um marco inicial da hotelaria planejada. As inovações foram os banheiros privativos em cada quarto e a uniformização dos empregados.

No Brasil, a hotelaria não evolui durante muito tempo porque simplesmente não existiam viajantes ou qualquer tipo de comércio. Registra-se que no século XVII em São Paulo aparece o primeiro hoteleiro, Marcos Lopes, seguido anos mais tarde pela cigana Francisca Rodrigues. Duarte (1996, p.19), expõe o modelo de hotelaria da época ao salientar que "a cigana Francisca Rodrigues, que montou sua estalagem e talvez o primeiro restaurante da gastronômica cidade de São Paulo - que anunciava, entre outras coisas, carne, biju e farinha", destacando que durante todo o século XVII, a atividade hoteleira era sempre exercida conjuntamente com outros ofícios, como barbeiros, sapateiros, alfaiates, que eram ao mesmo tempo artífices, vendeiros e estalajadeiros. Todos eram considerados vendedores de alimentos e hospedagem, sem maiores distinções.

Registram-se na evolução da hotelaria no Brasil algumas características, como a exigência de uma carta de recomendações para se hospedar em alguns hotéis e a participação da igreja católica que, em 1872, criou a Casa dos Hóspedes no Colégio da Companhia de Jesus, em Salvador.

Em São Paulo, capital, aparece a partir de 1870, vários empreendimentos hoteleiros. Duarte (1996, p. 16), relata que os pioneiros na capital paulista, dignos da denominação, começam a aparecer a partir de 1870. No Largo do Capim, atual Largo do Ouvidor, no centro antigo, o Hotel Palma; na Rua São Bento, o Hotel Paulistano; na Rua da Fundição, esquina com o Páteo do Colégio, o Hotel do Comércio; no Páteo do Colégio, o Hotel Universal do Francês Lefebvre; na Rua do Comércio, o Hotel Providência, de Madame Legarde, com bilhares; o Hotel das Quatro Nações, que mais tarde, sob a direção de José Migliano, passou a denominar-se Hotel Itália; o Hotel da França e o famoso Hotel D`Oeste; o Grande Hotel e os alloggios (pequenos hotéis italianos), onde a comida era farta e o vinho generoso. Podem-se observar claramente as origens européias desenvolvendo esse setor econômico.

Também no Rio de Janeiro a hotelaria evolui devido às suas belezas naturais e à música de Ari Barroso e Carmem Miranda, que começa a ser conhecida mundo afora. A inauguração do Hotel Copacabana Palace é um marco da evolução da hotelaria no Brasil, seguida da inauguração do Hotel Glória, com mais de 700 apartamentos.

O grande desenvolvimento da hotelaria no Brasil acontece na década de 40, graças ao incentivo dos governos estaduais que promovem a construção dos hotéis-cassino, destacando- 
se o Grande Hotel Araxá e Grande Hotel São Pedro, em Águas de São Pedro, e Grande Hotel de Poços de Caldas.

Após a proibição dos jogos no Brasil, a indústria hoteleira fica estagnada, voltando a crescer na década de 70. Conforme Campos (2003, p. 20), a década de 1970 marca também a chegada das bandeiras estrangeiras na hotelaria brasileira.

Em 1969, o Hilton abriu suas portas na Avenida Ipiranga, na cidade de São Paulo, então ponto de boas lojas, restaurantes e um centro expandido ainda não decadente. O Hilton trazia para os hóspedes brasileiros o conceito aberto de hotel como um ponto-de-venda de bens e serviços. Não que outros hotéis já não trabalhassem de alguma forma esse conceito.

Na década de 1970, a cidade do Rio de Janeiro recebeu um hotel com bandeira Sheraton, o Sheraton Rio Hotel \& Towers. Ainda na mesma década, São Paulo ganhou o Caesar Park (que trocaria de mãos em pouco tempo, passando para o grupo Aoki) e o Brasilton. Manaus ganhou o Tropical Manaus, Salvador ganhou o Bahia Othon Palace, Itaparica (BA) ganhou o primeiro Club Mediterranée no Brasil e a Accor inaugurou os primeiros Novotel no país. O Abril Cultural lança resorts padrão luxo, sob a marca Quatro Rodas em Recife, São Luis e Salvador. O Banco Real inicia a construção do hotel Transamérica, em São Paulo e, logo após, na região de Comandatuba.

Esta década é marcada também pela criação do Instituto Brasileiro de Turismo, Embratur, que viabiliza a aprovação de vários projetos ligados ao segmento do turismo e da hotelaria, incentivando os investidores por meio de financiamentos a longo prazo, principalmente para a construção de hotéis.

A crise econômica, o fim dos financiamentos em longo prazo e a "Lei do Inquilinato", faz da década de 80 um período de baixos investimentos da indústria hoteleira.

Estes fatores e as exigências do mercado levaram ao surgimento dos apart hotéis ou flat services, produto desenvolvido para atender à nova realidade do mercado, oferecendo assim, ao setor da construção um negócio, seguro e rentável. De sucesso imediato, os apart hotéis atendem às necessidades dos investidores devido ao seu custo relativamente baixo e, também, aos usuários que encontram uma solução mais barata de hospedagem.

O desenvolvimento da indústria hoteleira no Brasil entra numa nova fase na década de 90, quando o governo do presidente Fernando Collor de Mello, por meio do Banco Nacional de Desenvolvimento Econômico e Social, oferece uma linha de crédito especial para a construção de hotéis. O plano real gera o interesse dos investidores institucionais, principalmente dos Fundos de Pensão, atraídos pela possibilidade de grandes retornos sobre o capital aplicado. Esta década é marcada como um dos períodos de maior expansão da oferta 
da indústria hoteleira. Hotéis de luxo são inaugurados em todo o país, destacando-se: São Paulo (Meliá, Inter-Continental, Renaissance e Softel), em Belo Horizonte (Ouro Minas), em Porto Alegre (Sheraton), em Pernambuco (Blue Tee Cabo de Santo Agostinho e Summerville) e, na Costa do Sauípe, um complexo turístico surgido na Bahia com cinco hotéis de luxo. No Rio de Janeiro, hotéis de luxo foram reformados e adaptados às modernidades da informática: Copacabana Palace, Le Meridien e o Sofitel Rio Palace.

No final da década de 90, o capital estrangeiro começa a investir em hotéis no Brasil por meio das próprias cadeias hoteleiras como, por exemplo, a compra da rede Caesar Park pelo grupo mexicano Posadas; a construção do Grand Hyatt em São Paulo, com investimentos da própria Hyatt e do grupo argentino Libermann; o Marriott Copacabana com investimento total da Marriott Internacional; o novo Hilton em São Paulo, construído pela Hilton Internacional; e o grupo Pestana de Portugal, que adquire quatro hotéis: Salvador, Rio de Janeiro, Angra dos Reis e Natal.

No início deste século, o movimento no setor hoteleiro ocorre motivado principalmente pelos efeitos da globalização, a internacionalização das empresas, o aumento da competitividade, os custos mais acessíveis das passagens, entre outros.

A hotelaria no Brasil sentiu, como as demais organizações, os efeitos da globalização, com a chegada das grandes redes hoteleiras ao país, no início da década de 90.

Registra-se este fato em Ricci (2005, p. 9), ao esclarecer que nesta época, “o Brasil, como um todo, era desprovido de hotéis de categoria e os serviços eram deficientes". A hotelaria passou a ser a bola da vez. Os olhos dos investidores se voltaram para este nicho de mercado. Os empreendedores imobiliários tinham um produto triunfante nas mãos. Lembra, ainda, Ricci que o governo, na ausência de políticas de geração de empregos, levantou a bandeira que o turismo, e conseqüentemente, a hotelaria seriam geradores de empregos potenciais. O setor educacional apressou-se em criar novas escolas e cursos de hotelaria e turismo. Em menos de uma década, os principais centros do país ganhavam novos hotéis, com cara de primeiro mundo, repletos de novidades.

Para Beni (2003, p. 156), “a oferta hoteleira nacional tem alta concentração de equipamentos classificados entre quatro e cinco estrelas, praticando diárias em média de US\$ 80, reclamando um redirecionamento do equipamento instalado para evitar altas taxas de ociosidade na baixa estação". Ele menciona também que há 35 anos, quando a política oficial de turismo da Embratur, Instituto Brasileiro de Turismo, acenou com a possibilidade de atrair empresários para o setor, criando os Fundos de Investimentos de Hotelaria e Turismo, equivocou-se - embora alertada pelos profissionais e pesquisadores da área, com relação à 
importância da adequação desses investimentos às características sociais e econômicas do país, para o atendimento de seu luxo interno que só assim seria consolidado para poder alavancar o receptivo internacional, e acabou por assistir aos capitais incentivados, colocados à disposição, serem usados integralmente em hotéis de luxo.

Especificamente na região Nordeste, universo deste estudo, a evolução do turismo e o conseqüente investimento em infra-estrutura hoteleira também ocorreu a partir de 1990, com a criação do Programa de Ação para o Desenvolvimento Turístico do Nordeste (Prodetur), apresentado pelo Governo Federal - fato que vem confirmar a importância do turismo daquela região do Brasil.

O Prodetur tem como objetivo desenvolver o turismo sustentável com base no planejamento estratégico de longo prazo. As ações do programa são voltadas para a infraestrutura básica dos municípios, para fomentar a oferta turística, contribuindo para o desenvolvimento econômico da região Nordeste do Brasil. É um programa que procura equilibrar as obras com as condições ambientais, preservando aspectos culturais, produtivos e administrativos, garantindo a melhoria da qualidade de vida da população.

O programa foi concebido a partir de gestões de governadores do Nordeste, junto ao Banco do Nordeste, Superintendência do Desenvolvimento do Nordeste, Instituto Brasileiro e Turismo e Comissão do Turismo Integrado do Nordeste. Os agentes financeiros são o Banco Interamericano de Desenvolvimento e o Banco Nacional de Desenvolvimento Econômico e Social.

As obras de infra-estrutura consistem na construção ou reestruturação de estradas e desenvolvem ações de saneamento básico implantando sistemas de água e esgoto nos municípios contemplados, assim como a construção de equipamentos que contribuam para o desenvolvimento do turismo.

O programa prevê também a recuperação e o controle ambiental das praias, mananciais e lagoas, bem como a urbanização do entorno e a criação das Unidades de Conservação e Educação Ambiental. Outro ponto importante é o desenvolvimento institucional dos órgãos envolvidos no Prodetur, privilegiando treinamentos e fornecimento de equipamentos, além da participação ativa da população de cada município contemplado.

A partir deste programa, segundo a $\mathrm{ABIH}$, houve um investimento na construção de empreendimentos hoteleiros de mais de $30 \%$, nos últimos 10 anos.

O parque hoteleiro do Nordeste vem se expandindo a cada dia com os efeitos gerados pela globalização, o aumento da competitividade, a internacionalização das empresas, os custos mais acessíveis do transporte aéreo e outros fatores relacionados ao turismo. 
Estes apontamentos são registrados em Amazonas (2007, p. 3), ao destacar que o novo século assinala novos personagens no cenário de investimentos hoteleiros: Fundos de Pensão, pequenos investidores e grandes construtoras. O Governo começa a pagar as dívidas e, com opções mais seguras para empréstimos, os investimentos se voltam para o mercado imobiliário. Os imóveis comerciais e a segunda residência, conhecidos como imóveis turísticos, tornam-se as aplicações mais seguras. E mais, vale ressaltar que é neste cenário que aparecem no Brasil novos conceitos, como por exemplo, Hotel Boutique, e o Condor-Hotel. O Ministério do Turismo acredita que até 2008 haverá 117 novos empreendimentos hoteleiros, representando $\mathrm{R} \$ 3,6$ bilhões em investimentos, isso sem incluir dados dos pequenos e médios investidores. Neste panorama, o Nordeste brasileiro concentra a maior parte desses investimentos (46\%) e também as maiores quantias - $60 \%$ do total.

Como outros tipos de organizações, os hotéis necessitam, para atender aos mais variados tipos de hóspedes, de uma diferenciação em seus serviços. Para tanto, o hotel é classificado utilizando-se critérios.

Até o início deste século, no Brasil se utilizou da classificação dos empreendimentos hoteleiros por estrelas de uma a cinco; quanto maior o número de estrelas, maior a categoria.

Em 2002, o Ministério do Turismo e a ABIH, juntaram-se e criaram uma comissão de estudos para elaborar uma nova classificação.

A atual classificação, criada pela comissão, busca avaliar a qualidade dos serviços prestados pelos empreendimentos hoteleiros. São utilizados dois instrumentos para a classificação: o Manual de Avaliação, que mostram quais são os requisitos e quais são os seus valores para cada categoria de hotel, e uma Matriz de Classificação. Para as diferentes categorias são utilizadas as estrelas, de uma a cinco, ou a categoria superior, conforme descrito abaixo:

- Luxo superior, ou 5 estrelas.

- Luxo, ou 4 estrelas.

- Standard superior, ou 3 estrelas.

- Standard, ou 2 estrelas.

- Simples, ou 1 estrela.

A classificação não é obrigatória e seu processo demora de um a três anos. No Brasil existem, até o momento, 31 hotéis classificados pelo processo atual; destes, 14 na região Nordeste. 
O Guia Quatro Rodas, uma importante publicação da Editora Abril sobre turismo, incluindo hotelaria, utiliza como critério de classificação o conforto. Assim, segundo o mesmo, tem-se luxo, muito confortável, médio conforto, simples e em local agradável (com vista panorâmica).

A não obrigação da classificação possibilitou aos usuários a escolha, principalmente via Internet, das características do hotel onde se deseja hospedar, porém, tem gerado uma série de informações diversificadas no que diz respeito à quantidade de empreendimentos de hospedagem no Brasil e, conseqüentemente, no Nordeste - uma vez que o proprietário também não precisa se cadastrar em nenhum órgão ou entidade de classe.

Assim, para melhor delimitar o universo da pesquisa, buscou-se, por meio de informações fornecidas pelo Ministério do Turismo, Secretarias de Estado do Turismo, Guia Quatro Rodas e Associação Brasileira da Indústria de Hotéis, chegar a um número aproximado de hotéis da região Nordeste. O cruzamento dos dados resultou em aproximadamente 3000 empreendimentos no setor da hotelaria, o que constitui o universo desta pesquisa.

Com este cenário, pode-se afirmar, sem receio de incorrer em erros, que a área do turismo/hotelaria representa hoje um dos setores que mais crescem, desenvolvem-se e se especializam no país e, portanto, necessitam da comunicação para desenvolver suas atividades.

Acentua-se em Nielsen (2002, p. 97),

um entendimento mais profundo de que esses problemas de comunicação conferem aos gerentes e estudantes de turismo e comunicações algumas idéias de como conduzir o próprio comportamento referente a ela e o de seus clientes. Isso deve melhorar a troca de informação e o gerenciamento de organizações turísticas individuais e, dessa forma, assegurar que a indústria do turismo funcione, como um todo, com menos tropeços.

A comunicação de uma organização se dá nos âmbitos interno e externo e tem como objetivo promover a integração desta organização com os seus públicos. A comunicação é uma atividade abrangente, dividida em áreas. Este trabalho busca, essencialmente, entender a relação existente entre uma das áreas da comunicação, as relações públicas, e o turismo/hotelaria. Procura-se, ainda, demonstrar a interação das áreas de relações públicas e turismo/hotelaria necessária para a construção de bases para o desenvolvimento da área de relações nas organizações de turismo.

A literatura disponível sobre os conceitos de relações públicas, traz farto material, o que não é intenção repetir nem discutir neste estudo. Pretende-se, sim, diligenciar as 
referências bibliográficas que tratem das relações públicas como administração estratégica da comunicação e dos relacionamentos organizacionais. Desta feita, constata-se que autores como Margarida Kunsch, Roberto Simões, James Grunig, Cândido Teobaldo constituem a base necessária para a compreensão das atividades e funções das relações públicas, necessárias a este estudo, o que não inviabiliza a inserção de outros estudiosos da área.

As duas áreas, relações públicas e turismo/hotelaria, por todas as mudanças que passaram e ainda passam, na academia e no mercado, requerem uma adaptação contínua das suas atividades e uma adequação dos termos utilizados nas suas definições, especificamente as relações públicas.

Portanto, é necessário discutir algumas definições de relações públicas e hotelaria, que servirão de suporte para este trabalho. Segundo Simões (1995, p. 37), a literatura existente traz a definição conceitual da atividade de relações públicas equivalente aos seus objetivos e, outras, aos seus instrumentos e em outras á sua ótica.

Existe na esfera acadêmica e, conseqüentemente no mercado, uma inquietude em relação à definição do conceito de Relações Públicas. Em várias obras e até mesmo em eventos científicos, como os Congressos da Associação Brasileira de Relações Públicas, ABRP; da Sociedade Interdisciplinar de Comunicação, INTERCOM, e da Associação Brasileira de Pesquisadores em Relações Públicas e Comunicação Organizacional, ABRAPCORP, a definição conceitual de relações públicas é discutida e, por vezes, equivale aos seus instrumentos, aos seus objetivos.

Entidades e estudiosos de relações públicas procuram contribuir para uma definição única e aceitável, minimizando assim a complexidade e diversidade da profissão. A seguir, apresentam-se conceitos de autores e entidades de classe, nacionais e estrangeiros, selecionados a partir das concepções de relacionamento, organização, administração, comunicação e estratégias, que servirão de base para a discussão aqui proposta.

Kunsch (2003, p. 89), menciona as relações públicas como disciplina acadêmica e atividade profissional, que têm como objeto as organizações e seus públicos, instâncias distintas que, no entanto, se relacionam dialeticamente. "É com elas que a área trabalha, promovendo e administrando relacionamentos e, muitas vezes, mediando conflitos, valendose, para tanto, de estratégias e programas de comunicação, de acordo com diferentes situações reais do ambiente social". Ferreira (2006, p. 95), declara que:

para nós, relações públicas são os procedimentos da administração, sistematicamente estruturados, que se destinam a manter, promover, orientar e estimular a formação de públicos, "por meio da informação e da 
comunicação dirigida', a fim de tornar possível a coexistência dos interesses visados.

Integrando-se aos demais autores, Simões (1995, p. 83), cita que "a atividade de Relações Públicas é a gestão da função política da organização. Donde Relações Públicas (definens) é igual à gestão da função política da organização (definiendum) e esta gestão é somente a atividade de Relações Públicas e nenhuma outra".

A seguir, apresenta-se um quadro resumido de algumas definições:

\begin{tabular}{|c|c|}
\hline $\begin{array}{l}\text { ABRP - Associação Brasileira de } \\
\text { Relações Públicas. } \\
\text { Andrade }(1996,105) .\end{array}$ & $\begin{array}{l}\text { Entende-se por Relações Públicas o esforço deliberado, } \\
\text { planificado, coeso e contínuo da alta administração, para } \\
\text { estabelecer e manter uma compreensão mútua entre uma } \\
\text { organização, pública ou privada, e seu pessoal, assim como entre } \\
\text { essa organização e todos os grupos aos quais está ligada, direta ou } \\
\text { indiretamente. }\end{array}$ \\
\hline $\begin{array}{l}\text { IPRA - International Public Relations } \\
\text { Association } \\
\text { www.ipra.org }\end{array}$ & $\begin{array}{l}\text { Relações Públicas é a arte e a ciência de analisar tendências, } \\
\text { predizer consequiências, assessorar os líderes das organizações (alta } \\
\text { administração) e implantar programas de ação planejada que } \\
\text { sirvam tanto aos interesses da organização como aos do público } \\
\text { considerado. }\end{array}$ \\
\hline $\begin{array}{l}\text { Instituto Britânico de Relações } \\
\text { Públicas } \\
\text { Andrade, }(1993, \text { p.36). }\end{array}$ & $\begin{array}{l}\text { Entende-se por Relações Públicas o esforço deliberado, } \\
\text { planificado, coeso, contínuo, da alta administração para estabelecer } \\
\text { e manter compreensão mútua entre uma organização pública ou } \\
\text { privada e seu pessoal, assim como essa organização e todos os } \\
\text { grupos aos quais está ligada, direta ou indiretamente, entendendo- } \\
\text { se por grupos os acionistas, clientes, fornecedores, governo, } \\
\text { indústria, escolas, financiadores, etc. }\end{array}$ \\
\hline $\begin{array}{l}\text { Conferp } \\
\text { www.conferp.org.br }\end{array}$ & $\begin{array}{l}\text { A atividade e o esforço deliberado, planificado e contínuo para } \\
\text { estabelecer e manter a compreensão mútua, entre uma instituição } \\
\text { pública ou privada e os grupos e pessoas a que esteja direta ou } \\
\text { indiretamente ligada, constituem o objeto geral da profissão liberal } \\
\text { ou assalariada de relações públicas. }\end{array}$ \\
\hline $\begin{array}{l}\text { Confiarp } \\
\text { Andrade }(1996, \text { p.105). }\end{array}$ & $\begin{array}{l}\text { São uma atividade sócio-técnico-administrativa, mediante a qual se } \\
\text { avalia e se pesquisa a opinião e a atitude do público e se } \\
\text { compreende um programa de ação planificado, contínuo e de } \\
\text { comunicação recíproca, baseado no interesse da comunidade e } \\
\text { destinado a manter uma afinidade e compreensão da mesma para } \\
\text { com entidades de qualquer natureza. }\end{array}$ \\
\hline $\begin{array}{l}\text { Cândido Teobaldo de Souza Andrade } \\
\text { Andrade }(1993, \text { p.171). }\end{array}$ & $\begin{array}{l}\text { Relações Públicas são um método dinâmico resultante da aplicação } \\
\text { sistemática de ciências e técnicas em direção a um determinado } \\
\text { efeito, ou seja, a formação do público e, conseqüentemente, da } \\
\text { opinião pública como realidade. }\end{array}$ \\
\hline $\begin{array}{l}\text { Margarida Maria Kroling Kunsch } \\
\text { Kunsch }(2003, \text { p.102). }\end{array}$ & $\begin{array}{l}\text { Na prática, as relações públicas buscam criar e assegurar relações } \\
\text { confiantes ou formas de credibilidade entre as organizações e os } \\
\text { públicos com os quais elas se relacionam. Evidentemente, isso } \\
\text { exige tempo, pesquisas, auditorias, diagnósticos (para avaliar o } \\
\text { grau de relacionamento das organizações com os seus públicos), } \\
\text { planejamento, participação programada, implementação de } \\
\text { resultados. }\end{array}$ \\
\hline $\begin{array}{l}\text { Roberto Porto Simões } \\
\text { Simões (2001, p.63). }\end{array}$ & $\begin{array}{l}\text { A atividade de relações públicas é a gestão da função } \\
\text { organizacional política a fím de obter a cooperação dos públicos, } \\
\text { para a consecução da missão organizacional. }\end{array}$ \\
\hline $\begin{array}{l}\text { Waldir Ferreira } \\
\text { Ferreira }(2006, \text { p.95). }\end{array}$ & $\begin{array}{l}\text { Para nós, relações públicas são os procedimentos da administração, } \\
\text { sistematicamente estruturados, que se destinam a manter, } \\
\text { promover, orientar e estimular a formação de públicos, "por meio } \\
\text { da informação e da comunicação dirigida", a fim de tornar possível }\end{array}$ \\
\hline
\end{tabular}




\begin{tabular}{|c|c|}
\hline & a coexistência dos interesses visados. \\
\hline $\begin{array}{l}\text { Edward L. Bernays } \\
\text { Andrade, (1993, p.34). }\end{array}$ & $\begin{array}{l}\text { Relações Públicas tem três significados; primeiro; informação que } \\
\text { se dá ao público; segundo, a construção da estratégia que } \\
\text { centramos e dirigimos em direção ao público para modificar suas } \\
\text { atitudes e ações; e terceiro, a soma dos esforços para poder integrar } \\
\text { as atividades e ações de uma organização com seus públicos e os } \\
\text { do público com esta organização para ambos se beneficiarem. }\end{array}$ \\
\hline $\begin{array}{l}\text { Philip Lesly } \\
\text { Lesly (1995, p.03). }\end{array}$ & $\begin{array}{l}\text { Relações públicas pode ser definida como ajudar uma organização } \\
\text { e seus públicos a mutuamente se adaptar uns aos outros. }\end{array}$ \\
\hline $\begin{array}{l}\text { Jorge Pedro Sousa } \\
\text { Sousa }(2004, \text { p.14). }\end{array}$ & $\begin{array}{l}\text { As relações públicas podem ainda entender-se como um conjunto } \\
\text { de técnicas de comunicação planificada, porque as acções de } \\
\text { relações públicas são, na sua essência, acções de comunicação } \\
\text { articuladas e organizadas, que obedecem a planos, traçados com } \\
\text { objetivos determinados e em função dos orçamentos disponíveis. } \\
\text { As relações públicas, normalmente, implicam uma comunicação } \\
\text { bidirecional, que comporte o feedback, pois agem como o file da } \\
\text { balança entre as organizações e os seus públicos, implicando } \\
\text { mudanças num e noutro dos pólos da relação. }\end{array}$ \\
\hline $\begin{array}{l}\text { Raymond Simon } \\
\text { Simon (1994, p.18). }\end{array}$ & $\begin{array}{l}\text { As relações públicas constituem a função administrativa que avalia } \\
\text { as atitudes do público, identifica as políticas e os procedimentos de } \\
\text { uma organização com o interesse público e executa um programa } \\
\text { de ação e comunicação para obter a compreensão e aceitação do } \\
\text { público. }\end{array}$ \\
\hline $\begin{array}{l}\text { Fabio França } \\
\text { França }(2006, \text { p.4). }\end{array}$ & $\begin{array}{l}\text { Sendo a expressão "relações públicas" do ponto de vista filosófico } \\
\text { um termo em ampla extensão, torna-se difícil de ser compreendido, } \\
\text { na sua natureza própria, fato que é demonstrado pela dificuldade } \\
\text { encontrada para que se defina com precisão a sua diferença } \\
\text { específica. Esse posicionamento Leva-nos a recorrer ao uso de } \\
\text { conceitos que nos permitam tratar das relações públicas } \\
\text { focalizando com maior ênfase aspectos lógicos em detrimento dos } \\
\text { descritivos, mais comumente encontrados nas suas definições. }\end{array}$ \\
\hline
\end{tabular}

Quadro 1 - Conceitos de relações públicas.

Com a finalidade de ampliar a discussão, acrescenta-se às definições os 10 princípios genéricos de Relações Públicas, que foram identificados por Versic, L. Grunig e J. Grunig, 1996:

Estes princípios genéricos de Relações Públicas, antes 14 e depois 10, foram encontrados nos departamentos considerados excelentes, numa pesquisa realizada por um grupo de pesquisadores liderados por James Grunig: 1 - Envolvimento de Relações Públicas na administração estratégica: Uma organização que pratica Relações Públicas estrategicamente desenvolve programas para comunicar-se com seus públicos estratégicos, internos e externos, que proporcionam grandes oportunidades e ameaças para a organização. Construindo bons relacionamentos com esses públicos estratégicos, pode-se maximizar a autonomia das organizações para alcançarem suas metas estabelecidas; 2 - Participação total de Relações Públicas com a alta administração ou relacionamento direto com o executivo principal: Para a função de comunicação ser parte integral da administração estratégica de uma organização, Relações Públicas deve fazer parte da estrutura organizacional e o 
profissional deve fazer parte da alta administração ou, pelo menos, deve ter fácil acesso ao executivo principal; 3 - Função integrada de Relações Públicas: As organizações eficazes integram todas as funções de Relações Públicas dentro de um único departamento. Somente num sistema integrado de Relações Públicas é possível desenvolver novos programas de comunicação para conseguir mudanças nos públicos estratégicos; 4 - Relações Públicas como função administrativa, separada de outras funções: Relações Públicas excelentes é uma função separada as outras funções administrativas, como Marketing, Recursos Humanos, Jurídico ou Finanças. Quando a função Relações Públicas está subordinada a outro departamento não pode movimentar recursos comunicacionais de um público estratégico para outro e perde sua autonomia; 5 - Unidade de Relações Públicas coordenada por um 'administrador' mais do que por um 'técnico': Os técnicos de comunicação são essenciais para levar o dia-a-dia das atividades de comunicação de uma empresa. Entretanto, excelentes unidades de Relações Públicas devem ser administradas por um comunicador sênior, que deve ter como missão conceituar e dirigir os programas de comunicação; 6 - Uso do modelo de Relações Públicas simétrico de duas mãos: As Relações Públicas simétricas de duas mãos estão baseadas na pesquisa e usam a comunicação para administrar o conflito e melhorar o entendimento com os públicos estratégicos. Os departamentos de Relações Públicas excelentes desenvolvem seus programas de comunicação enfatizando as práticas do modelo simétrico; 7 - Uso do sistema simétrico de comunicação interna: Excelentes organizações têm estruturas administrativas descentralizadas que dão autonomia para os empregados e permitem que eles participem das tomadas de decisão; 8 - Profundo conhecimento do papel de administrador e de Relações Públicas simétricas: Os programas de Relações Públicas excelentes são conduzidos por profissionais - pessoas que possuem um conhecimento profundo na área; são ativos participantes das associações de classe e estão em dia com a literatura profissional; 9 Diversidade em todos os papéis desempenhados: O princípio do requisito variedade afirma que organizações eficazes possuem tanta diversidade quanto o ambiente. Relações Públicas excelentes incluem homens e mulheres em todos os papéis, tanto quanto profissionais de diferentes origens raciais, étnicas e culturais; 10 - Contexto organizacional para a excelência: Os departamentos de Relações Públicas excelentes são frutos de culturas mais participativas do que autoritárias, de pressões de ativistas no ambiente e por estruturas administrativas orgânicas ao invés de mecânicas. As organizações excelentes tendem a desenvolver estruturas organizacionais descentralizadas, que dão autonomia para os empregados e permitem-lhes participar da tomada de decisão. 
Percebe-se a grande quantidade de definições de relações públicas, porém, a semelhança entre elas fica evidente: o estudo do relacionamento da organização com os seus públicos por meio da comunicação.

Ferrari, confirma o exposto acima ao destacar que:

Sem entrar no mérito do conteúdo das definições de Relações Públicas que forma surgindo ao longo do tempo - de autoria tanto de entidades da categoria como de pesquisadores e estudiosos da profissão -, podemos afirmar, tranqüilamente, que hoje existe um consenso em relação ao seu conceito global, cuja aceitação é unânime pela comunidade de especialistas de Comunicação, principalmente em relação a sua função básica de administradora de relacionamentos (FERRARI, 2006, p. 86).

Complementam-se as definições destacadas com a lei Federal $\mathrm{n}^{\circ} 5.377$, de 11 de dezembro e 1967, que regulamenta a profissão:

A atividade e o esforço deliberado, planificado e contínuo para estabelecer e manter a compreensão mútua, entre uma instituição pública ou privada e os grupos de pessoas a que esteja direta ou indiretamente ligada, constitui o objeto geral da profissão liberal ou assalariada de relações públicas.

Evidencia-se, agora, o foco principal das relações públicas - a organização e o relacionamento com seus diversos públicos de interesse, fator imprescindível para as duas áreas. Outro fator importante para o sucesso das atividades de relações públicas e turismo/hotelaria é que as duas áreas só progridem numa sociedade democrática, onde a vontade de todos os interessados - proprietários, funcionários e comunidade -, deve ser ouvida e respeitada.

Como organização, o hotel é um negócio com produtos e mercados próprios. Uma organização de análises complexas que combina produção e venda sob o mesmo teto, onde os clientes consomem os produtos no ponto de venda.

Vários são os conceitos utilizados na definição de hotel: Para Medlik e Ingram (2002, p. 4), "um hotel é um estabelecimento que oferece hospedagem, alimentação e bebidas para os viajantes e residentes temporários e, freqüentemente, refeições e descanso, e muitas vezes outras instalações, para outros tipos de usuários".

O hotel é uma empresa prestadora de serviços que faz parte do sistema de turismo assim como os transportes e os atrativos. A gestão hoteleira necessita de visão estratégica para desempenhar suas atividades respeitando o meio que a envolve. Petrocchi (2007, p. 2), ressaltando este papel, considera que "a empresa hoteleira é a pessoa jurídica que explora ou administra meios de hospedagem, tendo como objetivos sociais o exercício da atividade 
hoteleira". Para ele, a hotelaria é uma parte do sistema de turismo e, como tal, interage com as demais partes, isso significa que existe uma interdependência entre o hotel e os demais integrantes do sistema: o hotel influencia o resultado do conjunto, assim sofre influências das outras partes. Como componente do sistema de turismo, o hotel apresenta números expressivos de geração de empregos diretos e indiretos, relação com os setores de eventos, alimentação, transportes, receptivo e outros.

Klein (1980, p. 31), define hotel como sendo uma edificação que, mediante pagamento de diárias, oferece alojamento à clientela de maneira indiscriminada. A legislação portuguesa amplia um pouco esta definição e, no Decreto Lei número 49.3990 - Portugal esclarece que hotel é um estabelecimento que tem por finalidade proporcionar alojamento, contra uma dada remuneração, com ou sem o fornecimento de refeições e outros serviços acessórios.

Molero (1974, p. 52), ressalta o detalhamento do conceito de hotel utilizado França, segundo o qual o hotel seria um estabelecimento comercial do alojamento classificado que oferece apartamento mobiliado ou habitação, em aluguel, pelo período de alguns dias, semanal ou mensal, o qual, no mais das vezes, não constitui domicílio do locador, esteja ele de passagem ou não. Pode apresentar ou não serviço de restaurante, o qual pode funcionar durante todo o ano ou em determinado período.

No Brasil, a Embratur considera oficialmente meio de hospedagem o estabelecimento que satisfaça as condições de licenciamento pelas autoridades competentes para prestação de serviços de hospedagem e seja administrado ou explorado comercialmente por empresa e que adote, no relacionamento com os hóspedes, contrato de hospedagem, de acordo com a legislação específica em vigor. Os meios de hospedagem deverão, no mínimo, oferecer aos hóspedes alojamento, para uso temporário do hóspede, em Unidades Habitacionais (UH) específicas para esta finalidade e ainda, serviços mínimos de: portaria/recepção, com o objetivo de controle de entrada e saída, guarda de bagagem e objetos de uso pessoal e conservação, manutenção, arrumação e limpeza das áreas, instalações e equipamentos.

Esclarecidas as atividades e função de um hotel, pode-se afirmar que as relações públicas são de grande valia para o sucesso e a permanência no mercado, dos empreendimentos hoteleiros, uma vez que estes têm nos seus hóspedes a fonte principal da manutenção de suas atividades, além de outros públicos. 


\section{CAPÍTULO II - PERCURSO METODOLÓGICO}

\section{1 - A PESQUISA}

Demonstrado o caminho teórico que se pretende seguir para a realização deste trabalho, entende-se ser este o momento de explicitar a base utilizada para a escolha da metodologia proposta para esta pesquisa. Assim, objetivando evidenciar o entendimento do pensamento dos autores, acrescidos de idéias próprias e opiniões, iniciou-se este estudo a partir da pesquisa bibliográfica, quando se realizou um planejamento global, que incluiu a identificação, a localização e a obtenção da bibliografia pertinente sobre o assunto, para que se pudesse apresentar um texto sistematizado a partir da literatura examinada.

Esta pesquisa percorreu um caminho dividido em duas etapas distintas: a primeira diz respeito à revisão bibliográfica e, a segunda, à pesquisa de campo.

Na pesquisa bibliográfica examinou-se a literatura sobre relações públicas, turismo, hospitalidade e hotelaria, enfocando as especificidades conceituais para se compreender a abrangência das duas áreas.

Desta forma, este trabalho tem como método principal a pesquisa qualitativa, o que não impossibilita a obtenção de dados quantitativos, uma vez que se entende que um método complementa o outro. Em face da natureza exploratória, descritiva e explanatória deste estudo, a pesquisa qualitativa oferece riqueza e profundidade necessárias para a compreensão dos significados que estão além dos dados coletados e que, na maioria das vezes, são possíveis somente por meio da pesquisa quantitativa. Outro fato que motivou a escolha da pesquisa qualitativa foi a grandiosidade do universo da mesma e, neste método, possibilita que numa pequena amostra existe a possibilidade de examinar fenômenos de uma perspectiva mais profunda. Os métodos qualitativos como: estudos de casos, focus groups, entrevistas em profundidade, observações em campo etc., são os mais indicados para se desenvolver pesquisas em relações públicas, uma vez que a pesquisa qualitativa é a mais indicada pelos estudiosos da área para investigar processos humanos complexos em constante mudança. No caso específico deste estudo, existe uma série de variáveis desconhecidas que são mais facilmente identificadas quando se utiliza o método qualitativo, uma vez que o objeto é verificar se a organização hoteleira desenvolve atividades de relações públicas que interferem em seu cotidiano.

A pesquisa qualitativa possui pressupostos contrários ao modelo experimental; o pesquisador é integrante do processo de conhecimento e interpreta os fenômenos, atribuindo- 
lhes um significado. Assim, a acuidade inventiva do pesquisador é fundamental para captar o universo das emoções e das interpretações do seu informante. Segundo Baptista, na pesquisa qualitativa o conhecimento não se reduz a um rol de dados isolados conectados por uma teoria explicativa. Ademais, o autor relata:

deixam a verificação das regularidades para se dedicarem à análise dos significados que os indivíduos dão às suas ações, no espaço que constroem as suas vidas e suas relações, ou seja, à compreensão do sentido dos atos e das decisões dos atores sociais, assim como dos vínculos das ações particulares com o contexto social mais amplo em que estas se dão. Há uma relação dinâmica entre o mundo real e o sujeito, entre o sujeito e o objeto, entre o mundo objetivo e a subjetividade do sujeito (BAPTISTA, 1999, p. $35)$.

O propósito da pesquisa é verificar se os hotéis da região Nordeste do Brasil desenvolvem funções e atividades de relações públicas, por quem são desenvolvidas e se existe um setor responsável pela elaboração de políticas que sustentem e direcionem estas atividades. Assim, entende-se que seriam identificados pontos positivos e negativos, problemas enfrentados para o desenvolvimento das atividades, avaliação dos programas existentes e, ainda, criar expectativa para implantação de novas políticas e atividades.

Para responder à hipótese e atingir os objetivos propostos, esta pesquisa buscou informações nos hotéis localizados no litoral da região Nordeste do Brasil, de acordo com a classificação proposta na amostra.

Pelo conflito existente entre as formas de classificação dos hotéis, já exposto anteriormente, optou-se por utilizar neste trabalho, como fonte para identificar o universo da pesquisa, o Guia Quatro Rodas, por se entender ser esta uma publicação com credibilidade no mercado editorial brasileiro, com 43 anos de existência e tiragem média de 20 mil exemplares, em seu último número, 2008.

O Guia Quatro Rodas, Edição 2008, esclarece aos seus leitores que os critérios para seleção e inclusão de hotéis e restaurantes vêm sendo aprimorados a cada ano. Afirma ainda que não é cobrada nenhuma taxa dos estabelecimentos citados e não aceitamos cortesias. Atualizamos ao máximo o nosso banco de dados até a véspera do fechamento de cada edição. As notas atribuídas a cada hotel, assim como a sua posição dentro de cada categoria, são discutidas pelos repórteres com editores especializados. Observa-se e pontuam-se os tipos de apartamentos, a área social, área de circulação, conservação, localização, estrutura, lazer e a prestação de serviços. Quanto mais alta a categoria, mais itens para serem analisados devem existir no hotel. Exemplifica-se: num aposento observam-se e avaliam-se vários itens existentes, tamanho da TV, tipos de travesseiros, tecidos da roupa de cama. Assim, a 
qualidade e o conjunto permitem a atribuição de uma nota e a comparação com outros da mesma categoria. Chega-se, então, à avaliação final e à definição da categoria. No Guia, as avaliações das notas são publicadas em ordem decrescente. Ressalta-se, porém, que nas avaliações são levadas em consideração as informações deixadas pelo repórter do ano anterior.

\section{2 - ESCOLHA DO TEMA.}

A temática desta pesquisa se insere na extensa fronteira das atividades de relações públicas aplicadas ao turismo/hotelaria e vice-versa, o que é por demais complexo. Por isso, menos que querer abarcar o tema de forma exaustiva, pretende-se pontuar questões pertinentes ao assunto, identificando nas atividades de relações públicas e turismo/hotelaria algumas concepções de ordem epistemológica, teórica e metodológica que possam favorecer a seleção de determinadas configurações da realidade mais próxima, geralmente tematizadas acriticamente, dentro de um paradigma dominante, que podem resultar em interpretações insatisfatórias, superficiais ou errôneas. São os fatores implicados nesse processo e suas especificações que poderão verificar se as verdades e comprovações produzidas pela academia interferem no processo histórico-social das relações públicas e do turismo/hotelaria, haja vista que comumente ocorrem atitudes rígidas de adesão e defesa total a um paradigma e conseqüente menosprezo dos outros. Nesse sentido, na maioria das vezes, encontra-se nos "nichos" de mercado uma grande utilidade como passaporte para o exercício da profissão nas mais variadas atividades da sociedade, sempre que realizado com disciplina, eficácia e criatividade. O campo profissional, das relações públicas exige uma nova abordagem conceitual que explicite a existência de conflitos nos mais variados tipos de organizações. Não se devendo esquecer, todavia, que os processos comunicacionais são submetidos a constantes pressões nacionalizadoras/globalizadoras - o que requer uma constante preocupação em sintonizá-los com as tendências nacional-mundiais, desprovincianizando a formação profissional, legitimando as aspirações dos jovens profissionais em galgar postos de trabalhos em organizações que encabeçam as redes às quais estão vinculadas as organizações local-regionais.

$\mathrm{Na}$ era da transnacionalização das culturas, das economias e das técnicas, a maneira pela qual se efetivam as articulações entre o local/regional representa um momento necessário no movimento da universalização/globalização. Ainda que apareça um paradoxo, mas a própria dinâmica do sistema mundial, ligado ao processo de globalização, torna necessária a 
preservação do local/regional. O local/regional representa um espaço privilegiado no que diz respeito a esta diversidade. O caso do Nordeste brasileiro é, a este respeito, particularmente interessante: apesar de ser uma região periférica do Brasil, devido principalmente a questões econômicas, consegue inserir-se na cultura brasileira, inclusive acadêmica, transferindo seu caráter regional para o nacional e, por vezes, universal - se levar em conta suas tradições culturais, seu carnaval, sua música popular, seu litoral e suas cidades históricas.

Assim, a proposta desta pesquisa se apresenta como nova, justificando-se pela procura de marcas que revelem uma identidade regional que visem caracterizar e diagnosticar as principais ações capazes de minimizar as chances de insucesso das organizações hoteleiras que se estabeleceram no Nordeste do Brasil. O entorno local/regional em que os hotéis estão situados, deverá ser necessariamente o ponto de partida para a sua realização.

Enfatizar os "nichos" de mercado como objeto de estudo tem sido alvo de interesse de inúmeras pesquisas, que o refletem teoricamente e analisam empiricamente, a partir de seus respectivos paradigmas. Mas, enquanto campo acadêmico, vocacionado para a interdisciplinaridade, considerando os assuntos tratados nos mesmos, pouco se fez até agora. Os pesquisadores, em sua maioria, vêm insistindo estudar as atividades de relações públicas, direcionando seus trabalhos para grandes centros econômicos brasileiros e suas Instituições superiores de ponta, relegando para o segundo plano regiões menos desenvolvidas do país, onde estudos nesta área encontram-se praticamente inexplorados, como se não tivessem nenhuma importância no cenário nacional. Porém, ainda que regionalizada, esta pesquisa poderá ultrapassar os limites geográficos do Nordeste, uma vez que determinadas situações que por ventura aí se encontrem não são totalmente estranhas ao resto do país.

Eis que despontam as intenções e os objetivos da pesquisa. O enfoque deste estudo tentará avançar numa perspectiva de propor uma articulação conceitual que reforce a prática das atividades de relações públicas no campo do turismo/hotelaria e facilite o estabelecimento de marcos de operacionalização metodológica, permitindo vislumbrar novas abordagens, novas tendências e maior abrangência temática. Além de ganhos estruturais, entende-se que o delineamento desta pesquisa se mostra relevante por pretender facilitar a discussão sobre a necessidade de desenvolvimento das relações públicas na área de turismo/hotelaria. Assim, o tema 'atividades de relações públicas na hotelaria do Nordeste', poderá trazer novos conceitos e paradigmas para a compreensão da comunicação na organização hoteleira. 


\section{3 - PROBLEMA.}

Constatou-se, por meio de documentos do Ministério da Educação, o aumento da quantidade de cursos de relações públicas na região Nordeste nos últimos anos. Percebeu-se, também, o grande número de empreendimentos hoteleiros que têm surgido na última década, na mesma região. Dessa constatação, pode-se afirmar que a área da hotelaria está cada vez mais se firmando como uma atividade econômica organizada, valorizando a atividade turística no Brasil.

Esta pesquisa tem como propósito indagar, verificar e responder o questionamento: as atividades de relações públicas estão sendo desenvolvidas na rede hoteleira do Nordeste brasileiro?

\section{4 - HIPÓTESE.}

O mercado turístico/hoteleiro da região Nordeste do Brasil pode ser um espaço de atuação do profissional de relações públicas, por meio de implementação e conhecimento dessas atividades por parte dos gestores de turismo/hotelaria.

\section{5 - OBJETIVOS.}

\subsection{1 - Objetivo geral.}

Identificar, analisar e avaliar se as atividades de relações públicas estão acontecendo nos hotéis da região Nordeste do Brasil e, conseqüentemente, instituir procedimentos para propor uma articulação conceitual entre estas áreas, que reforce a sua prática e facilite o estabelecimento de marcos de operacionalização metodológica, resultando em abertura do mercado de trabalho.

\subsection{2 - Objetivos específicos.}

- Diagnosticar dúvidas e deficiências temáticas sobre relações públicas em relação ao turismo/ hotelaria e vice-versa.

- Elaborar procedimentos que colaborem para a eficiência e a eficácia das atividades de relações públicas no mercado turístico/hoteleiro. 
- Identificar se os empreendimentos hoteleiros da região Nordeste possuem em seus quadros de funcionários, profissionais de relações públicas.

- Diagnosticar, nos hotéis estudados, os programas de relacionamento com os diversos públicos e quem os executa.

\section{6 - SELEÇÃO DE FONTES.}

Definido o tema, realizou--se o levantamento bibliográfico (bibliotecas da Universidade Federal do Maranhão e da Escola de Comunicações e Artes da Universidade de São Paulo e livrarias de São Paulo), identificando na bibliografia disponível o material que serviria de suporte ao estudo pretendido. O produto desta identificação é uma lista, a mais completa possível, de documentos representativos para a investigação.

Não se perdeu de vista que a primeira fonte para indicar a bibliografia pertinente ao tema escolhido é o orientador. Ademais, recorreu-se a fontes bibliográficas secundárias, como: portais, índices com resumo, resumos de teses e dissertações, catálogos de bibliotecas, catálogos de editoras, sites oficiais, etc. E por fim, a seleção dos hotéis onde foi realizada a pesquisa de campo.

\section{7 - LEITURA E TRANSCRIÇÃO DE DADOS.}

Utilizou-se, no caso, um fichamento eletrônico, via computador, onde se guardou as informações em arquivos, com possibilidade de ampliar, corrigir, ordenar, remover ou substituir as anotações.

\section{8 - ALGUNS PRESSUPOSTOS METODOLÓGICOS.}

O delineamento do estudo proposto necessita, portanto, de uma visão mais holística do processo de pesquisa social, para que ele possa incluir a definição e a revisão de um problema, sua teorização, a coleta de dados, a análise dos dados e a apresentação dos resultados. Sob o ponto de vista que interessa este estudo, a pesquisa foi descritivoexploratória, utilizando os métodos qualitativos, com a finalidade de demonstrar o campo do turismo/hotelaria, procurando-se conhecer a realidade, sem nela interferir para modificá-la.

O objetivo da entrevista em profundidade é a interpretação e a compreensão do comportamento, das atitudes e dos padrões humanos do entrevistado. As entrevistas foram 
realizadas pessoalmente pelo investigador, garantindo dessa forma que as questões fossem respondidas em sua complexidade e que as mesmas tivessem o caráter de uma conversa com objetivos determinados, respeitando a maneira como os entrevistados estruturaram suas respostas. $\mathrm{O}$ entrevistador procurou aplicar a técnica de ouvir, não emitindo opiniões.

\section{9 - UNIVERSO.}

Diante deste quadro, o universo da pesquisa compõe-se de 3000 empreendimentos hoteleiros da região Nordeste do Brasil.

\subsection{0 - CONSTITUIÇÃO DA AMOSTRA.}

A amostra será de 02 hotéis, por Estado, podendo ultrapassar este número, a depender das circunstâncias de cada Estado da região, localizados na área litorânea, buscando atender aos critérios de: muito confortável, médio conforto e confortável.

Exemplifica-se:

- Estado de Alagoas

- Jatiúca Hotéis e Resorts - muito confortável

- Hotel Meliá Maceió - médio conforto

- Ponta Verde Praia Hotel - confortável

\subsection{1 - TÉCNICA AMOSTRAL.}

Probabilística por capital dos Estados do Nordeste, que estejam localizadas no litoral. Exclue-se aqui o Piauí, onde a pesquisa foi realizada na única cidade litorânea do Estado que atendia o universo amostral, Luiz Correia, vizinha à cidade de Parnaíba. Registra-se que foram feitas 05 tentativas para se chegar à cidade. Três vezes tentou-se, via São Luis, Maranhão, duas vezes via Teresina, Piauí. Em todos os casos não foi possível o acesso devido a chuvas fora de época, que ocasionaram a interdição das estradas.

Foi estabelecido que fosse entrevistado um funcionário que pertencesse ao quadro gestor do hotel, ou seja, buscou-se por um setor de comunicação. Quando não houvesse a existência do mesmo, procurou-se uma atividade afim, como os setores de eventos e/ou marketing. 
Quanto ao estabelecimento hoteleiro, este foi selecionado por meio de sorteio desde que estivesse localizado na capital litorânea, e cumprisse as exigências propostas na amostra. $\mathrm{Na}$ hipótese de recusa do estabelecimento em responder a pesquisa, o mesmo não seria substituído. Porém, registre-se que em todas as cidades da amostra foram ultrapassados os números de hotéis pesquisados.

No pré-teste, identificou-se que seria necessário um dia para realizar cada uma das pesquisas, portanto foram estipulados 03 dias em cada capital para a realização da mesma.

Buscou-se ainda, realizar a pesquisa em baixa temporada, uma vez que a alta temporada acarreta nos hotéis uma lotação de quase cem por cento, o que dificultaria a disponibilidade de um funcionário para responder à pesquisa. Assim, as visitas aos hotéis ocorreram em 2008, conforme descrito abaixo:

- Primeira quinzena de abril - Ceará, Maranhão e Piauí.

- Primeira quinzena de maio - Pernambuco, Paraíba e Rio Grande do Norte.

- Primeira quinzena de junho - Bahia, Sergipe e Alagoas.

\subsection{2 - ELABORAÇÃO DO INSTRUMENTO DA PESQUISA.}

A metodologia utilizada para esta coleta inicial é a entrevista em profundidade, individual ou em grupo, com natureza semi-estruturada, uma vez que, além da direção que se pretende dar ao estudo, é importante estar aberto para novas possibilidades que o objeto de estudo possa apresentar. Assim, entendeu-se que o instrumento mais adequado para a realização desta pesquisa é um protocolo previamente estabelecido, porém, que permita a inclusão de novas informações. O conteúdo do protocolo foi elaborado a partir das funções e atividades de relações públicas constantes na segunda parte do instrumento. A primeira parte foi reservada para a identificação do estabelecimento hoteleiro.

\subsection{3 - PRÉ-TESTE}

Uma vez produzido o protocolo, o mesmo foi revisado e aprovado pelo orientador. O pré-teste serviu para averiguar aspectos das entrevistas como: perguntas repetitivas, ambigüidades de perguntas, tempo gasto em cada entrevista, ordem de apresentação e quantidade de perguntas, necessidade ou não de maiores explicações sobre as perguntas. $\mathrm{O}$ pré-teste serviu também para verificar parâmetros de confiabilidade, validade e operacionalidade. Buscou-se atentar para questões éticas e operacionais. 
O pré-teste foi realizado em abril de 2007, nas cidades do Recife e Salvador, em dois hotéis de cada cidade e, após a análise, foram efetuadas as correções necessárias.

\subsection{4 - ANÁLISE DOS DADOS.}

As entrevistas foram realizadas com funcionários dos departamentos de marketing, eventos e com gerentes, uma vez que os hotéis da amostra, em sua totalidade, não possuem departamentos de comunicação. Os entrevistados possuem formação em nível superior, nas mais variadas áreas: administração, turismo, hotelaria, psicologia, relações públicas. Identificou-se que os hotéis pesquisados possuem em média 200 funcionários, distribuídos em três turnos. Sempre localizados no litoral, os hotéis estão geralmente, disposto um ao lado do outro nas cidades pesquisadas. Em se tratando da classificação, os entrevistados afirmaram que não se preocupam mais com isso e, continuam usando as classificações antigas. Esta afirmação vem acompanhada sempre da explicação que o importante é oferecer ao hóspede qualidade, principalmente baseados no ISSO 9001/2000 E ISSO 14001. Portanto, hoje a preocupação maior é participar dos programas de qualidade. 


\section{CAPÍTULO III - RELACIONAMENTOS ESTRATÉGICOS/RELAÇÕES PÚBLICAS}

\section{1 - FUNÇÕES E ATIVIDADES DE RELAÇÕES PÚBLICAS}

Este capítulo resgata estudos sobre as funções e atividades das relações públicas e reforça o importante valor que as relações públicas possuem para a sociedade e para a organização. Não é objetivo aprofundar-se no estudo da sociedade e das organizações e, sim, identificar o papel que as organizações ocupam dentro dela e sua relação com os públicos que interferem na sua existência.

Estudiosos buscam, ao longo dos tempos, entenderem como funcionam as organizações por meio das teorias da administração - que começou a ganhar vulto com a publicação do livro Princípios da administração científica, de Frederic Taylor em 1911. Nos últimos anos, os estudos de Garre Morgan (1996), denominado Imagens da Organização, têm merecido atenção por apresentar de forma simples e de fácil compreensão a organização moderna, vista por meio de metáforas.

A complexidade da sociedade e das organizações, suas perspectivas e suas características podem ser percebidas em Morin (2007, p. 46), quando analisa o mundo moderno. Para ele, o mundo atual não se pode conceber como um sistema organizado,

racional. É um caos, é uma vertigem em movimento. É muito difícil de entender o que se passa. É exatamente como disse Ortega y Gasset: "Não sabemos o que passa. E é isso que se passa". Esta dificuldade de entender o mundo é uma coisa muito angustiante porque quanto mais estamos nesta possessão do mundo sobre nós menos somos capazes de entendê-lo e de atuar.

Ademais, deve-se dizer que o mundo se encontra cada vez mais uno e cada vez mais particularizado, diga-se, cortado em pedaços. Uno no sentido de que cada parte do mundo faz parte cada vez mais do mundo em sua globalidade. E que o mundo em sua globalidade encontra-se dentro de cada parte. Isto vale também para os indivíduos. Tome-se um europeu médio. De manhã, liga seu rádio japonês, toma café da América Latina, põe a camisa de algodão da Índia, uma calça de lã da Austrália, uma carteira de réptil africano. Tem rum da Martinica, tequila mexicana, saquê e talvez cachaça brasileira. Escuta sinfonia alemã, com a direção de um maestro coreano ou japonês. Nas misérias das favelas africanas, asiáticas e da América Latina também há presença do mercado mundial, porque é o mercado que afeta o custo do cacau, do açúcar, do café. 
A visão do mundo contemporâneo, formado por frações separadas e ao mesmo tempo unificado, suas rupturas, suas inovações e as rápidas mudanças que acontecem, buscou-se entender em Srour (1998, p. 325), ao expor que “o mundo contemporâneo está vivendo extraordinárias rupturas de forma insensível". Destacando ainda, que a soma de inovações tecnológicas, o florescimento de modos novos de convivência social, as comunicações instantâneas ou em tempo real, a velocidade dos transportes, a superação incessante das fronteiras do conhecimento científico, a economia do saber ou 'quaternária', a consolidação do terceiro setor, o fortalecimento ímpar da sociedade civil estão redesenhando os espaços sociais.

Srour, examina com propriedade as transformações que ocorrem no cenário mundial, alertando que:

todas essas transformações, no entanto, não resultam de algum voluntarismo altruísta. Decorreram das inúmeras pressões que a cidadania organizada exerceu no cotidiano das empresas e das ruas. E o processo de intervenção política da sociedade civil veio testando as suas forças e veio redefinindo as relações capitalistas desde o período entre as duas guerras mundiais (SROUR, 1998, p. 20).

Menciona, ainda, que o novo desenho conjuga leis de mercado e planejamento indicativo do Estado, faculta parceria entre Estado e sociedade, amarra as ações das organizações a pautas morais de caráter social, facilita o acesso da população aos benefícios gerados pelas inovações tecnológicas, distingue as organizações estatais das organizações públicas (não-governamentais) no atendimento às necessidades de consumo coletivo, amplia, por fim, o espaço público, fazendo com que o interesse comum readquira sua natureza primordial de controle exercido pelos cidadãos sobre a coisa pública (respublica).

Entender como funciona a sociedade atual e, na medida do possível, identificar a intervenção do homem em benefício da vida planetária e, particularmente, da vida humana, tem sido o grande desafio de estudiosos da atualidade.

Morin, professa sua crença na humanidade e na capacidade do indivíduo em manterse uno e múltiplo na unidade, ao afirmar que:

a chegada do novo milênio não o afastou do compromisso com a transformação: o futuro povoa o imaginário dos homens e cobra projeções que revelam, no mínimo, preocupações legítimas com o bem estar das gerações do amanhã. Sofre-se no presente a antecipação do devir (MORIN, 2007, p. 17).

Ele alerta que a humanidade experimenta hoje a decadência de um tipo de idéia de futuro. Cabe construir uma nova concepção de porvir passível de acolher uma confluência de 
sonhos. O amanhã é um rio que corre desde sempre na mente de cada ser banhado pelo sol da igualdade.

Assim, entende-se que a verdade científica não é a única verdade que alimenta o homem. A religião, a arte, os mitos povoam a humanidade. Morin conclui, por fim, que "não há humanidade sem imaginário." Para resolver os problemas de sua existência o homem busca na felicidade, a solução, desprendendo produtivamente a sua energia e a sua inteligência, o que aumenta sua participação no contexto social.

A visão de um mundo não apenas tecnicista, mas povoado de paradigmas, pode ser detectada em Buber (2004, p. 72), quando alerta que o homem vive num mundo povoado de duplicidades. "O mundo é duplo para o homem, pois sua atitude é dupla". Ele percebe o ser em torno de si, as coisas simplesmente e os entes como coisas; ele percebe o acontecimento em seu redor, os fatos simplesmente e as ações enquanto fatos, coisas compostas de qualidades, fatos compostos de momentos, coisas inseridas numa rede espacial, e fatos numa rede temporal, coisas e fatos limitados por outras coisas e fatos mensuráveis e comparáveis entre si, um mundo bem ordenado e um mundo separado. Este mundo inspira confiança, até certo ponto; ele apresenta densidade e duração, numa estrutura que pode ser abrangida pela vista, ele pode ser sempre retomado, repetido com olhos fechados e experienciado com olhos abertos; ele está aí, junto à tua pele, se tu o consentes encolhido em tua alma, se tu assim o preferes.

Neste novo cenário, a atitude das pessoas é considerada uma das maiores forças do atual século, uma vez que essas atitudes determinam o que ocorre dentro de uma organização. Este clima de constantes mudanças é o espaço ideal para a atuação do profissional de relações públicas. Entende-se que cabe às relações públicas identificar como agem estes grupos por meio de elementos que agregam a psicologia, política, economia, cultura, etc. Assim, sob vários aspectos, a sociedade moderna se organiza e se dinamiza pelas relações existentes entre organização/indivíduos e organização/organização. No mundo cada vez mais complexo em que se vive particularmente nas grandes cidades, interage-se com diversos tipos de organização: industriais, bancos, Estado, supermercados etc.

Confirma-se em Dias, ao destacar que:

$\mathrm{Na}$ vida contemporânea, uma parte substancial de nossas atividades econômicas de trabalho, políticas, sociais, culturais tem lugar em organizações das quais somos membros, clientes, contribuintes, espectadores, defensores, vítimas etc. embora a sociedade atual seja uma sociedade de classes, tem também sentido afirmar que -sem prejuízo da afirmação anterior- é uma sociedade de organizações. Estas têm propósitos 
bem diversos, reúnem interesses variados - às vezes, conflitivos - de seus membros têm uma vida intensa e a elas dedicamos partes crescente de nossa existência (DIAS, 2003, p. 25).

As transformações por que passa a sociedade, a ruptura que transfigura a contemporaneidade, cria novos cenários e formas de atuação das organizações. Estudiosos da psicologia visualizam as organizações como verdadeiros campos de batalha, onde as contradições estão espalhadas por todos os lados. As mudanças que ocorrem sistematicamente nos ambientes organizacionais, obriga, de certa forma, as organizações a quebrarem modelos autocráticos e totalmente hierarquizados. Assim, as organizações são obrigadas a estabelecer relações democráticas entre os diversos níveis de trabalhadores, ocasionando relações de conflito.

Em Srour, entendem-se as novas relações sociais das organizações, haja vista que ele destaca que as relações que estruturam as organizações são relações coletivas que abrangem e conectam coletividades. Operam no plano público e impessoal, focalizam as atenções das Ciências Sociais, se distinguem pela formalidade de seu caráter, e não se confundem com as relações interpessoais, por serem relações 'associativas', mediadas pela existência de meios de produção.

As organizações formam assim um espaço em que agentes sociais, munidos de instrumentos de trabalho, processam matérias-primas e as transformam em produtos finais. Por serem fenômenos sociológicos, as organizações são singularidades históricas e se inscrevem num plano institucional (1998, p. 109).

As organizações, dada a necessidade de se adequarem à nova ordem mundial, têm outro posicionamento perante a sociedade, conscientes de que além de construir sua imagem institucional fazem parte de um cenário onde a responsabilidade do bem-estar social é atribuída a elas pelos seus grupos de relacionamento e por toda a sociedade.

Ianhez (2006, p. 186), enfatiza as atribuições da organização ao afirmar que "hoje as organizações já estão sendo julgadas e consideradas pelo público não apenas pelas suas performances em vendas, lucros e produtividade, mas sim pelas suas contribuições à sociedade, pelos compromissos que têm com o bem comum". Ele explica que estarão destacadas dentro dessas contribuições suas atuações na área de bem-estar da sociedade, não apenas a benemerência. Esta área exigirá cada vez menos das empresas, pela concentração das ações governamentais, em todo o mundo, nas áreas de educação, saúde, saneamento básico, amparo à infância e à velhice. O destaque para a ação da empresa estará na sua contribuição para a qualidade de vida nas comunidades e nações em que atua, políticas e práticas ambientais, políticas e práticas de relações com os funcionários, defesa de valores e princípios 
éticos. A sociedade cobrará das organizações, sejam elas de que tipo for, um forte senso de justiça e ligação, com base na fraternidade entre as pessoas, na consciência de que o que tem mais valia é o ser humano e seus sentimentos e não os bens materiais.

\section{2 - RELACIONAMENTO ORGANIZAÇÃO-PÚBLICOS.}

O relacionamento entre a organização e seus públicos, dá-se por meio de um conjunto de técnicas científicas a partir do conhecimento profundo da organização e dos grupos a ela ligados. Vários autores discutem o relacionamento de uma organização com seus públicos.

Por ser o relacionamento, entre a organização e os seus públicos, fundamental para o desenvolvimento das atividades de relações públicas, considera-se que é importante compreender como se processam as relações.

Buber, anuncia o princípio das relações, a questão da reciprocidade:

Relação é reciprocidade. Meu tu atua sobre mim assim como eu atuo sobre ele. Nossos alunos nos formam, nossas obras nos edificam. O mau se torna revelador no momento em que a palavra-princípio sagrada o atinge. Quanto aprendemos com as crianças e com os animais! Nós vivemos no fluxo torrencial da reciprocidade universal, irremediavelmente encerrados nela (BUBER, 2004, p. 63).

A ontologia da relação apresentada por Buber, na obra $E u$ e $T u$, apresenta também uma descrição fenomenológica da atitude do homem no mundo. A busca do conceito de relação, não é baseada em conceitos abstratos e se revela por meio das experiências do homem. Assim, a relação passa a ser vista como a manifestação do ser ao homem, onde a palavra é portadora do ser, é o lugar onde o ser se instaura como revelação. Entende-se assim que o ponto primordial da relação é o diálogo.

Buber, professa:

Pode-se supor que as relações e os conceitos, e também a representação de pessoas e coisas se desligaram dos eventos de relações e de estados de relação. As impressões e as emoções elementares, que despertaram o espírito do "homem natural", são derivadas de fenômenos de relação, pela vivência de um face-a-face, por estados de relação, pela vida na reciprocidade. Ele não pensa na lua que vê todas as noites, até o dia em que, no sono ou na vigília, ela se dirige para ele em pessoa e se aproxima dele, enfeitiça-o com gestos ou lhe proporciona algo, ao tocá-lo agradável ou desagradável. O que ele conserva desse fato não é a imagem ótica de um disco ambulante e nem a imagem de um ser demoníaco que, de algum modo, lhe pertencesse, mas primeiramente a imagem dinâmica, a imagem excitante daquela força lunar 
irradiante que perpassa o corpo. A imagem pessoal da lua e de sua força atuante se definirá somente aos poucos. Somente então a lembrança daquilo que ele recebeu de um modo inconsciente, noite após noites, começa a reavivar, permitindo-lhe apresentar e objetivar o autor e o portador daquela ação. Somente agora o Tu, originalmente inexperianciável, só agora recebido, torna-se um Ele ou Ela (BUBER, 2004, p.64).

A questão da reciprocidade é fundamentada por Buber (2004, p.69), ao verificar que o homem mesmo em sua fase primitiva da vida busca incessantemente relacionar-se. $\mathrm{O}$ instinto de relação é primordial e a criança, de uma forma primitiva e não-verbal, encontra a maneira de experimentar tudo o que lhe será apresentado. A originalidade da aspiração de relação já aparece claramente desde o estado mais precoce e obscuro. Antes de poder perceber alguma coisa isolada, os tímidos olhares procuram no espaço obscuro algo de indefinido; e em momento em que, aparentemente não há necessidade de alimento, é sem finalidade, ao que parece, que as suaves e pequeninas mãos gesticulam, procuram algo de indefinido no vazio. Afirmar que se trata de um gesto animal, é nada exprimir. Pois estes olhares, na verdade, depois de minuciosas tentativas, se fixarão em um arabesco vermelho de um tapete e dele não se desprenderão até que a essência do vermelho se lhes tenha revelado. Estes movimentos em contato com um ursinho de pelúcia, tomarão uma força sensível e precisa e tomarão conhecimento carinhoso e inesquecível de um corpo completo. Muitos movimentos, chamados reflexos, são um instrumento indispensável à pessoa na construção do seu mundo. Complementam-se os estudos de Buber, (2005, p. 78), que especifica como se comporta o homem dentro do grupo ao qual pertence:

À medida que as experiências constitutivas do aprendizado social se repetem se acumulam, os traços que deixam cada uma delas se sobrepõem se combinam, se reforçam, interiorizando-se cada vez mais profundamente, transformando-se em disposições gerais, isto é, a repetição de uma situação diante da qual aprendemos a distinguir um comportamento legítimo de outros ilegítimos (socialmente reprováveis). Temos uma tendência, sem necessitarmos de uma orquestração consciente das vantagens e desvantagens sociais de cada comportamento possível, a agir de forma a reproduzir a ordem social, de acordo com as disposições interiorizadas.

A relação do homem com as instituições às quais está ligado é a sua 'vida pública', que deve ser separada da sua vida 'particular', porém, devem caminhar juntas para que o homem se encontre.

A delimitação entre a vida pública e a vida privada está sempre ameaçada, pois os sentimentos penetram ás vezes nas mais sólidas instituições. Buber (2004, p. 79), salienta que as instituições são o 'fora', onde se está para toda sorte de finalidades, onde se trabalha se faz negócios, se exerce influência, se faz empreendimentos, concorrências, onde se organiza, 
administra, exerce uma função, se prega: é a estrutura mais ou menos ordenada e aproximadamente correta na qual se desenvolve, com o concurso múltiplo de cabeças humanas e membros humanos, o curso dos acontecimentos. Para ele os sentimentos são o 'dentro', onde se vive e se descansa das instituições. Aí o espectro das emoções vibra diante do olhar interessado; aí o homem usufrui sua ternura, seu ódio, seu prazer e sua dor, quando esta não é muito violenta. Aí a gente se sente em casa, se estira na cadeira de balanço.

A idéia do Eu e Tu, segundo Buber (2004, p. 73), torna-se uma verdade fundamental do mundo humano, onde o Tu significa o 'homem' e o Isso, aquilo que pode ser ordenado, o que pode ser mexido, manipulado. O mundo do Isso é coerente no espaço e no tempo. $\mathrm{O}$ mundo do Tu não tem coerência nem no espaço e nem no tempo. Cada Tu, após o término do evento da relação deve necessariamente se transformar em Isso. Cada Isso pode, se entrar no evento da relação, tornar-se um Tu. Estes são os dois privilégios fundamentais do mundo do Isso. Eles impelem o homem a considerar o mundo do Isso como o mundo no qual se deve viver, no qual se pode viver, o mundo que oferece toda espécie de atrações e estímulos de atividades e conhecimentos. E com toda a seriedade da verdade, ouça: o homem não pode viver sem o Isso, mas aquele que vive somente com o Isso não é homem.

A complexidade em abordar as questões das relações inter e/ou intra-pessoais, não se restringe aos estudos da filosofia. Essa dificuldade é também encontrada na sociologia, na administração, na psicologia, na comunicação etc. Para este trabalho, a importância está nas relações existentes entre as pessoas e os grupos às quais elas pertencem, isto é, as relações sociais.

Em Andrade (1996, p. 103), encontra-se a definição das relações existentes entre as pessoas, as relações humanas. Ele considera a disciplina que aspira descobrir princípios de interação humana para alcançar mútua compreensão, respeito e cooperação. São relações funcionais, intragrupais, diretas, face a face, associadoras e éticas: podem ser abertas ou cerradas. Cabe notar: se a origem é o homem e também, sua meta, não só devem ser funcionais, como também profundas e dignas. Dentro dos grupos primários se dá a sua máxima expressão.

As relações que envolvem as pessoas causam divergências que são conhecidas como conflitos, que numa organização precisam ser identificados e resolvidos o quanto antes para não causar danos a todos. Os conflitos fazem parte da vida das organizações, pois a divergência entre uma ou mais partes, ou entre duas ou mais posições está sempre presente no momento de definir sobre qual o melhor caminho para atingir as metas organizacionais. Nas organizações os conflitos acontecem entre indivíduos, entre indivíduos e grupos, entre grupos 
e entre organizações. Embora não seja objeto desta pesquisa vale aqui registrar os tipos de conflitos que podem atingir e influenciar no desenvolvimento de uma organização.

O conflito interno é aquele que acontece quando o indivíduo está dividido entre duas posições opostas ou quando existem dois caminhos a serem percorridos para atingir uma meta, ou ainda quando o indivíduo esta envolvido em situações nas quais seu senso de valor entra em choque com o que a organização está propondo. Este tipo de conflito tem duas facetas, segundo estudiosos no assunto: primeiro podem assumir dimensões alarmantes ao causar doenças e segundo pode ser instigador de novas idéias estimulando a inovação na resolução de problemas, sendo benéficos para a organização.

Os conflitos entre indivíduos nas organizações são vistos como o resultado das diferenças de personalidades e ocorrem no desenvolvimento das funções organizacionais, quando os indivíduos competem entre si. Conflito entre indivíduos e grupos ocorre quando o indivíduo não concorda com as normas do grupo ou com a cultura da organização. Conflito entre grupos geralmente acontecem devido à competição por recursos ou aos estilos gerenciais diferentes dos setores. Os conflitos entre as organizações acontecem devido à competição para conquistar o consumidor. Geralmente estes conflitos são regulamentados pelo governo e órgãos especializados por meio de normas e leis.

Todos os tipos de conflitos organizacionais nascem de várias fontes potenciais que, segundo Montana e Charnov (1998, p. 325), são: “(1) diferença de metas; (2) competição pelos recursos; (3) falta de comunicação e da má interpretação da informação; (4) divergências sobre os padrões de desempenho e (5) incongruências da estrutura organizacional". As estratégias para gerenciamento dos conflitos de grupos são expostas no quadro abaixo, elaborado pelos mesmos autores.

\begin{tabular}{|c|c|c|c|}
\hline Estratégias & Base Racional & Pontos fortes & Pontos Fracos \\
\hline Abstenção & $\begin{array}{l}\text { Os gerentes } \\
\text { problema, } \\
\text { prom tratar do } \\
\text { acreditando quitas vezes } \\
\text { problema } \\
\text { "desaparecerá". }\end{array}$ & $\begin{array}{l}\text { Evita que os gerentes percam } \\
\text { tempo com problemas que } \\
\text { podem se resolver por conta } \\
\text { própria. }\end{array}$ & $\begin{array}{l}\text { Não trata das causas, faz com } \\
\text { que os gerentes ignorem } \\
\text { assuntos que são vitais para a } \\
\text { organização. }\end{array}$ \\
\hline Abrandamento & $\begin{array}{l}\text { Os gerentes desejam enfatizar a } \\
\text { harmonia na organização. }\end{array}$ & $\begin{array}{lr}\text { Harmonia } & \text { dos } \\
\text { relacionamentos; } & \text { paz } \\
\text { superficial entre } & \text { os } \\
\text { trabalhadores. } & \end{array}$ & $\begin{array}{l}\text { Não trata das causas } \\
\text { verdadeiras; muitas vezes cria } \\
\text { apenas a ilusão de resolução do } \\
\text { problema. }\end{array}$ \\
\hline $\begin{array}{l}\text { Dominação ou } \\
\text { Intervenção de } \\
\text { Poder }\end{array}$ & $\begin{array}{l}\text { Os gerentes desejam resolver o } \\
\text { conflito rapidamente e manter a } \\
\text { estrutura de poder existente }\end{array}$ & $\begin{array}{l}\mathrm{O} \text { conflito é resolvido de } \\
\text { maneira mais rápida. }\end{array}$ & $\begin{array}{lrr}\text { Não trata } & \text { das } & \text { causas } \\
\text { verdadeiras; o } & \text { conflito pode } \\
\text { não } & \text { ser } & \text { resolvido; } \\
\text { desenvolvimento } & \text { de } \\
\text { sentimentos ruins entre a chefia } \\
\text { e seus funcionários. }\end{array}$ \\
\hline $\begin{array}{ll}\text { Acordo } & \text { ou } \\
\text { concessão } & \\
\text { Mútua } & \\
\end{array}$ & $\begin{array}{l}\text { Os gerentes desejam satisfazer } \\
\text { pelo menos parcialmente a } \\
\text { posição de cada parte. }\end{array}$ & $\begin{array}{l}\text { Cada parte recebe alguma } \\
\text { coisa - todos "ganham" }\end{array}$ & $\begin{array}{lrr}\text { Não trata } & \text { das } & \text { causas } \\
\text { verdadeiras; } & \text { não } & \text { satisfaz } \\
\text { nenhuma parte } & & \\
\end{array}$ \\
\hline
\end{tabular}




\begin{tabular}{|l|l|l|l|}
\hline Confronto & $\begin{array}{l}\text { Os gerentes desejam chegar na } \\
\text { "raiz" do conflito }\end{array}$ & $\begin{array}{l}\text { A administração trata das } \\
\text { causas do conflito e chega a } \\
\text { uma solução funcional que } \\
\text { força todos os envolvidos a } \\
\text { conciliarem suas exigências. }\end{array}$ & $\begin{array}{l}\text { gerenciado } \\
\text { adentimentos ruins; corre-se o } \\
\text { risco de os gerentes se } \\
\text { envolverem demais com as } \\
\text { raízes do problema e nunca } \\
\text { resolverem. }\end{array}$ \\
\hline
\end{tabular}

Quadro 2 - Resolução de conflitos.

Fonte: MONTANA e CHARNOV (1998, p. 332).

Nenhuma organização está livre de conflitos, todas elas sofrem ou se beneficiam desses conflitos. Depende do gerenciamento e das habilidades dos gerentes e do compromisso da organização com o gerenciamento dos conflitos, bem como a metodologia dos relacionamentos que irão determinar como o conflito, influirá na organização. Os relacionamentos das organizações com os seus públicos refletirão positiva ou negativamente nas resoluções dos conflitos.

Encontra-se em França (2006, 6), a base para o relacionamento existente entre organização e seus públicos. "Com efeito, relacionamento indica sempre reciprocidade, interdependência, troca e busca de vantagens comuns. É fundamental para qualquer organização, tanto sob o enfoque mercadológico quanto corporativo. Relações Públicas atuam de forma mais ampla e profunda do que o marketing de relacionamento". É inerente à sua natureza estabelecer a compreensão mútua entre as organizações e sua rede de públicos com o objetivo final de conquistar a sua credibilidade.

Ferreira, destaca:

1. Ato ou efeito de relacionar (se). 2. Capacidade, em maior ou menor grau, de relacionar-se, conviver ou comunicar-se com os seus semelhantes. É pessoa de relacionamento difícil. 3. Bras. Ligação de amizade, afetiva, profissional, etc. condicionada por uma série de atitudes recíprocas; relação (FERREIRA, 1999, p. 1735).

Marchiori (2004, p. 89), ressalta a responsabilidade das relações públicas nas mudanças que ocorrem nas organizações, ao discorrer que em um processo de mudança é fundamental a definição da forma de socialização dos indivíduos, principalmente considerando-se a existência de conflitos que estarão surgindo naturalmente por causa do contexto vivenciado pela organização, os quais deverão ser trabalhados, para a efetividade desse processo. Afinal, ninguém deseja que uma mudança não tenha continuidade.

Portanto, precisamos trabalhar na essência, no fundamento das relações, para que as pessoas possam envolver-se com a mudança proposta. Consideramos que o conjunto de ações em termos de estrutura e pessoas é que proporciona um dos grandes meios para atingir a mudança. O plano a ser criado deve 
atentar para o delineamento das várias e diferentes influências e orientações que ocorrem nas organizações e como esses fatores provocam impacto na interpretação destes eventos (MARCHIORI, 2004, p. 89).

Grunig (2003) apud Ferrari (2006, p. 87), evidencia a eficácia dos relacionamentos harmoniosos entre organizações e públicos, explicando que as organizações são eficazes quando definem e alcançam objetivos importantes para ela e para seus públicos estratégicos. "Neste sentido, as Relações Públicas podem contribuir com resultados mensuráveis enquanto gerenciam a construção de relacionamentos com os públicos que afetam ou são afetados pelas ações organizacionais". Tal relacionamento está baseado no vínculo e no comprometimento com que ambos, organização e públicos, compactuam diante de uma situação de escolhas múltiplas ou de impasse.

No cenário atual onde estão inseridas as organizações, percebe-se o poder que os grupos possuem sobre as mesmas questionando sua legitimidade, sua missão, sua atuação. Assim, cabe às relações públicas a tarefa de formar e informar estes grupos. $\mathrm{E}$, ao profissional de relações públicas, cabe fundamentar o relacionamento estratégico contribuindo para que a organização renove, sempre que necessário, suas políticas e seu desempenho de acordo com as tendências emergentes.

Este novo relacionamento, públicos/organização, fica evidente em Fortes (2003, p. 82), na assertiva de que os atuais grupos de relacionamento das organizações passaram a se comportar como se fossem os 'novos proprietários' da empresa, os quais não compreendem somente os donos da companhia, investidores institucionais e individuais e credores, mas igualmente todos os indivíduos e grupos de interesse que exercem pressões sobre os procedimentos estratégicos das corporações e estão sujeitos a serem afetados de diferentes maneiras pelas decisões do comando das organizações.

Entende-se por função de relações públicas as políticas e estratégias elaboradas para atender aos anseios da organização e de suas relações com os seus públicos de interesse.

Segundo Falconi, se todos os grupos de públicos estratégicos de uma organização forem cuidadosamente mapeados de acordo com cada objetivo específico:

é muito provável que a função de relações públicas (ou comunicação, assuntos públicos, relações externas, institucionais etc.) saia reforçada em importância na estrutura organizacional, assumindo a responsabilidade dos relacionamentos organizacionais com os públicos estratégicos (2006, p. 43). 


\section{3 - ORGANIZAÇÕES E SEUS PÚBLICOS.}

$\mathrm{Na}$ sociedade democrática as organizações existem num ambiente composto por vários grupos distintos de pessoas, os quais, didaticamente, denominam-se públicos, que interferem direta ou indiretamente na sua eficácia. Estes grupos podem aprovar ou oporem-se às metas organizacionais, influenciando a missão das organizações.

Não é objetivo deste trabalho estudar a fundo as discussões acerca do conceito de públicos. Porém, faz-se necessário delimitar qual o caminho que a presente pesquisa percorreu e aceitou para identificar públicos de uma organização.

Registra-se inicialmente a classificação de Fortes (2003, p. 70), que considera o ponto crucial para as relações públicas. Sua classificação decorre dos níveis de contigüidade espacial e de relacionamento empresa/grupo e grupo/empresa. O grau de aproximação é o somatório do trato financeiro e social, da conformação jurídica, do objetivo do negócio para o sucesso dos grupos atraídos, e da maior ou menor interferência nos destinos da organização.

Após analisar os estudos de autores brasileiros e internacionais, França (2002, p. 70), apresenta uma proposta de classificação de públicos. Apresenta-se uma síntese de sua proposta, a seguir:

Públicos essenciais: são os grupos de pessoas necessárias para a constituição e sobrevivência da organização.

Públicos não essenciais: pela sua importância, esses grupos contribuem para a projeção da empresa e para a manutenção de vários serviços. Não estão diretamente ligados aos fatores produtivos da organização. Não executam atividades-fim da organização, executam as atividade-meio.

Públicos concorrentes: são grupos que competem em qualidade, durabilidade, preço, inovação e atendimentos, isto é, representam qualquer organização que ofereçam no mercado os mesmos produtos ou serviços.

Públicos internacionais: importantes para organizações que atuam no mercado internacional. É um dos mais importantes para tais organizações, principalmente quando pesquisam concorrentes que possam vir afetá-las (FRANÇA, 2002, p. 70)

Para Oliveira e Nader (2006, p. 102), “cada organização tem seus públicos específicos, estratégicos, alvo, hoje denominados stakeholders". São grupos, pessoas, entidades, instituições, movimentos com algum tipo de relação com as organizações, seja por pertencerem a ela, ou por haver nesta relação interesses mútuos ou, ainda, por afetarem ou serem afetados direta ou indiretamente por suas atividades, mas sempre gerando e demandando expectativas. É o suficiente para que passem a exercer algum tipo de influência nas decisões, estratégias, formas de gestão e atuação das organizações. 
Assim, entende-se que as relações públicas são a administração estratégica dos relacionamentos existentes entre uma organização e seus públicos, com fins de harmonia e equilíbrio de interesses. Uma tarefa nada simples, uma vez que os conflitos, as controvérsias e os interesses são divergentes de grupo para grupo.

A classificação de públicos para a presente pesquisa é a que considera público como grupos de interesse para a organização. Quanto à classificação em interno, externo e misto, entende-se que é necessária para definir quais os instrumentos de comunicação são os melhores para atingir os objetivos de relações públicas.

\section{4 - A IMPORTÂNCIA DAS RELAÇÕES PÚBLICAS NA SOCIEDADE ORGANIZACIONAL.}

Para realizar e manter as atividades que são exigidas das organizações, a comunicação exerce papel fundamental, uma vez que é por meio dela que a missão da organização se torna conhecida e compartilhada por todos. O equilíbrio comunicacional e o fluxo de correto das informações entre as partes que formam a organização resultarão num processo eficiente e eficaz. Percebe-se assim, que as relações públicas ao longo do seu desenvolvimento têm direcionado seu foco para harmonizar a comunicação nas organizações tornado-se imprescindível para a sobrevivência da organização na sociedade globalizada.

Em Martins (2003, p. 38), busca-se perceber o valor atribuído às relações públicas dentro do novo perfil de comunicação. Nele encontram-se explicações esclarecendo que "as novas tecnologias trazem contribuições que são refletidas especialmente na maneira de comunicar e delineiam um novo perfil para a própria comunicação". A comunicação reconhece a finalidade de ações de Relações Públicas para construir relacionamentos com públicos estratégicos, para desenvolver uma comunicação global que seja compatível com este universo globalizado. Tem-se uma demanda cujo sentido é muito mais amplo do que a idéia simplista de uma sociedade de consumo. Hoje a sociedade é composta por públicos estratégicos, que irão se manifestar em resposta ao nível e à qualidade da comunicação que os atingem.

Lesly (1995, p. 2), ressaltando a necessidade das relações públicas na sociedade contemporânea, considera que:

Relações Públicas é um fenômeno e uma necessidade dos nossos tempos. Foi criada pelas forças que aumentaram o ritmo do mundo, colocando as pessoas em muitos grupos diversificados, todos buscando objetivos 
diferentes, mas, no entanto, todas precisando trabalhar juntas no sentido de obter vantagens e progresso comuns (LESLY, 1995, p. 2).

Desta forma, a crescente complexidade da civilização tem criado problemas que não eram sequer imaginados quando classificações sociais, econômicas, políticas e religiosas eram mais simples e bem separadas.

A prática das relações públicas vai depender da estrutura de cada sociedade, suas crenças e tradições, o avanço nos meios e instrumentos de comunicação, o acesso à informação e sua cultura. Porém, entende-se que os princípios para sua aplicação são sempre os mesmos. Assim, pode-se afirmar que as relações públicas possuem abrangência global. Tanto que, segundo Freitas e Santos (2002, p. 21), “cabe às Relações Públicas, hoje, um papel bem mais prospectivo e transformador do que aquele que as caracterizou ao longo destes quase 50 anos de profissão no Brasil". Mesmo os instrumentos de comunicação dirigida, tão próprios ao contexto de RP, ganham novos contornos, ao lado de tecnologias e ferramentas provenientes de outros campos do conhecimento. Porém, o que vai permitir que as Relações Públicas se destaquem no cenário contemporâneo é justamente esta sua assimilação como filosofia organizacional, responsável por uma auditoria contínua da empresa quanto ao seu grau de credibilidade e solidez do conceito corporativo. Lembremos que estes aspectos são fundamentais, hoje, para um posicionamento mercadológico significativo diante da concorrência.

A importância das relações públicas e a abrangência de suas atribuições na sociedade atual são destacadas por Nassar (2007, p. 31), ao afirmar que "as relações públicas, na abrangência e com a importância social a elas atribuída atualmente, são vistas como consequiência da evolução social, cultural, política, tecnológica e econômica das sociedades industriais, principalmente as ocidentais". Nesse contexto inicial, datado dos séculos XIX e $\mathrm{XX}$, elas se apresentam como processo político democrático fundamental para o entendimento entre os inúmeros protagonistas sociais nacionais e internacionais, que podem divergir em seus interesses, objetivos e formas de pensar e operar questões ligadas principalmente às relações de produção e às demandas da sustentabilidade ambiental, social e econômica.

\section{5 - FUNÇÕES E ATIVIDADES DE RELAÇÕES PÚBLICAS.}

Vários são os enfoques dados às funções de relações públicas, porém todos colocam as relações públicas como uma função estratégica que colabora para aceleração das tomadas 
de decisões das organizações. Neste contexto o profissional deve atuar como estrategista, analisando cenários e estudando os ambientes, interno e externo.

Confirma-se este contexto em Falconi (2006, p. 45), ao apontar que "os estudiosos mais progressistas afirmam que a verdadeira função estratégica das relações públicas na organização é refletiva/reflexiva, que, por sua vez, se integra inevitavelmente com o papel educativo". Mencionando também que ao lado da adoção de ferramentas e métodos mais ou menos sofisticados, este processo consiste no desenvolvimento de competências dos profissionais de relações públicas para realizar a análise de cenários, o estudo dos ambientes internos e externos e a gestão dos assuntos emergentes. Isso implica que as relações não apenas apóiam as organizações na modificação do cenário externo influenciando os seus públicos estratégicos essa prática é mais comum de ser entendida; é o 'papel operacional', mas também, e possivelmente mais importante, apóiam as organizações em seu próprio crescimento ao interpretar corretamente as expectativas dos públicos (tal atitude é a menos comum de ser entendida; é o 'papel estratégico').

O Parlamento Nacional de Relações Públicas, realizado pelo Conselho Federal de profissionais de Relações Públicas, CONFERP, teve como objetivo principal a modernização da atividade adequando-a às novas exigências da sociedade globalizada. Durante quatro anos, o Conselho promoveu a discussão em fóruns, congressos e nas suas seções regionais. Os profissionais interessados tiveram a oportunidade de se manifestar colocando suas dúvidas, sugestões, posicionamentos. $\mathrm{O}$ material coletado foi formatado sob a orientação do CONFERP, que o tornou público em reuniões regionais. Em 1997, em sua 17 Reunião, realizada no dia 21 de dezembro, em Brasília, DF, o Órgão Consultivo aprovou as conclusões do Parlamento Nacional de Relações Públicas que, entre outras conclusões, define como funções básicas de relações públicas:

- Diagnosticar o relacionamento da organização com os seus públicos;

- Prognosticar a evolução da reação dos públicos diante das ações das organizações;

- Propor políticas e estratégias que atendam às necessidades de relacionamento das organizações com seus públicos;

- Implementar programas e instrumentos que assegurem a interação das organizações com seus públicos.

Autores como Margarida Kunsch, Todd Hunt, Roberto Porto Simões, entre outros, defendem que as relações públicas são parte integrante do sistema organizacional, ou seja, 
como sendo 'um subsistema organizacional, exercendo funções essenciais e específicas, para sua interação com ambiente com ação conjunta dos seus vários subsistemas'.

Kunsch, ao focalizar as relações públicas na administração, salienta:

Podemos, na nossa concepção, aproveitar as quatro teorias mencionadas para indicar, como possíveis funções essenciais para o processo de planejamento e gestão das relações públicas nas organizações, as seguintes: a função administrativa (teoria interorganizacional), a função estratégica (teoria de gerenciamento), a função mediadora (teoria da comunicação) e a função política (teoria de conflitos-resoluções) (KUNSCH, 2003, p. 100).

Cada uma destas funções é analisada sob a visão de vários autores por Margarida Kunsch. (2003). A seguir destacam-se pontos importantes e fundamentais desta análise.

Função Administrativa: como função administrativa, as relações públicas, por meio de suas atividades específicas, visa atingir toda a organização, fazendo articulações necessárias para maior interação entre setores, grupos, subgrupos. Na prática, as relações públicas buscam criar e assegurar relações confiantes ou formas de credibilidade entre as organizações e os públicos com os quais se relacionam. Evidentemente, isso exige tempo, pesquisas, auditorias, diagnósticos (para avaliar o grau de relacionamento da organização com os seus públicos), planejamento, participação programada, implementação e avaliação de resultados. A função administrativa tem como suporte os autores: James Grunig e Todd Hunt, Raymond Simon, João Alberto Ianhez.

Função Estratégica: numa perspectiva moderna, as relações públicas precisam demonstrar sua contribuição também como um valor econômico para as organizações. Isto é, suas atividades têm de apresentar resultados e ajudar as organizações a atingir seus objetivos, cumprir sua missão, desenvolver suas visão e cultivar seus valores. Assim como função estratégica, as relações públicas devem, com base na pesquisa e no planejamento, encontrar as melhores estratégias comunicacionais para prever e enfrentar as reações dos públicos e da opinião pública em relação às organizações dentro da dinâmica social. A análise da função estratégica tem como sustentação o trabalho desenvolvido pelo professor Dr. Waldir Gutierrez Fortes, que afirma ser as relações públicas estratégicas "o inter-relacionamento entre escopo de mercado e os públicos, identificando as oportunidades e ameaças".

Função Mediadora entre as organizações e seus públicos: é uma função precípua de relações públicas, que não podem prescindir da comunicação e do uso de todos os seus meios possíveis e disponíveis. A comunicação é um instrumento vital e imprescindível para que as relações públicas possam mediar relacionamentos organizacionais com a diversidade de públicos, a opinião pública e a sociedade em geral. Destaque-se ainda que, em sua função 
mediadora, as relações públicas têm a responsabilidade de fazer a leitura do ambiente, por meio de uma auditoria social, intermediando as relações das organizações com a sociedade. As relações públicas por meio da comunicação, viabilizam o diálogo entre a organização e seu universo de públicos, sendo essa mediação uma de suas funções essenciais. Autores como Teobaldo de Souza Andrade, Marques de Mello, e os quatro modelos identificados por James Grunig, dão sustentação à função das relações públicas como mediadora entre as organizações e seus públicos.

Função Política: cabe às relações públicas, no exercício da função política e por meio da comunicação, gerenciar problemas de relacionamentos internos e externos, surgidos ou provocados pelo comportamento de determinados públicos e/ou por certas decisões das organizações. E é no âmbito do poder micro e macro que tudo isso ocorre. São instâncias que permeiam todo o processo de negociação e da busca de solução numa dimensão pública. Roberto Porto Simões, Ehling, White e Grunig sustentam a discussão e análise da função política das relações públicas feita por Kunsch "como função política, as relações públicas lidam basicamente com as relações de poder dentro das organizações e com a administração de controvérsias, confrontações, crises e conflitos sociais que acontecem no ambiente do qual fazem parte".

Roberto Porto Simões percorre um caminho que passa pelas teorias política e micro política, pela psicologia (formação acadêmica do autor), pela teoria dos sistemas e muitos outros estudos para demonstrar que "a atividade de Relações Públicas não significa exclusivamente o exercício de técnicas, mas na sua essência, uma tecnologia bem fundamentada em teoria política". Afirma também que "a visão do exercício desta atividade exige, antes de tudo, um estrategista nas relações de poder em nível de Micropolítica e, secundariamente, um tarefeiro na execução de instrumentos de comunicação.”.

Assim fundamentado, o autor defende como principal função de relações públicas a função política. Para tanto, Simões utiliza a teoria sobre as disciplinas, baseado em Pirie (1988) apud Simões (2001) "Pirie desenvolveu a teoria sobre as disciplinas, argumentando que cada uma, quer seja da natureza, quer do social, implica dois elementos: o processo e o programa."

Simões (2001, p. 33), destaca ainda que “o processo refere-se à estrutura do fenômeno, ou seja, aos seus componentes e à sua dinâmica. Contém o fenômeno em si com todo seu entorno, caracterizado por eventos subseqüentes". Nele se localizam as variáveis independentes, aquelas que ocorrem ao natural, sem a intervenção consciente e intencionada do ser humano. O fenômeno pode ocorrer de inúmeras maneiras. Pode ser benéfico ao ser 
humano, mas pode, também, prejudicar a sociedade ou parte desta. O programa é entendido como a formação de políticas, após a análise do processo. Afirma, ainda, que "o processo de Relações Públicas, ou o processo sóciopolítico, possui na organização um 'termostato' intrínseco a ele. Trata-se da função organizacional política que, quando ocorre em bom nível, mantém o processo funcionando adequadamente à consecução da missão da organização.”.

Quanto ao programa, Simões (2001, p. 35) conclui explicando que "o programa, por sua vez, refere-se à ação consciente e intencional de intervenção, pelo ser humano no processo, tanto para mantê-lo em determinada direção quanto para corrigir seu rumo". Ao programa cabe a tarefa de diagnosticar e prognosticar o processo, orientar os líderes organizacionais para nele interferirem e, a seguir, elaborar e executar o discurso da organização, explicando ou justificando a ação organizacional, a fim de evitar ou resolver mal-entendidos entre a organização e seus agentes com influências.

Desta forma Simões (2001, p. 36), define conceitualmente a atividade de relações públicas como "a gestão da função organizacional política", e aponta quatro operações necessárias para a gerência do programa, a saber: diagnóstico, prognóstico, assessoramento e implementação.

Para completar e entender a análise do autor destaca-se pontos importantes no seu trabalho sobre programas e funções de relações públicas.

Simões (2001, p. 36), declara que "as duas primeiras operações - diagnosticar e prognosticar - são preparatórias e essenciais para a realização das duas posteriores: assessorar nas políticas administrativas e implementar programas de comunicação". É aceitável considerar e designar o conjunto destas quatro operações, ou funções básicas, como a definição operacional da atividade. A definição operacional explica o que faz a atividade. Estas quatro operações se implicam subseqüentemente em ordem lógica:

- O diagnóstico: antes de tudo é imprescindível diagnosticar o processo. O diagnóstico é a conclusão da análise de como se encontra a organização em face dos interesses de todos os seus públicos ou de um especificamente. Isto implica de início, a busca de dados, ou seja, pesquisar sobre a organização, sua missão, seus públicos, seus interesses, os canais de comunicação com o público e também sobre a conjuntura local, regional, do país e, muitas vezes, mundial.

- O prognóstico: após o diagnóstico, deve-se inferir o que acontecerá no futuro, prever, caso nada ou algo seja feito pelos líderes organizacionais, em termos de modificações nas políticas organizacionais. O prognóstico é o fenômeno mental de 
juntada de dados do aqui e agora com as possibilidades das evoluções internas e externas da organização para o futuro.

- O assessoramento ao programa: após diagnosticar e prognosticar o processo cabe a tarefa de assessorar as lideranças organizacionais quanto às políticas administrativas e, a seguir, em outra etapa, implementar programas planejados de comunicação a fim de que a consecução da missão organizacional seja eficaz.

- Implementar projetos de comunicação: esta fase contém os projetos, constituídos das diversas tecnologias implicadas nos diversos sentidos do termo comunicação. Pode ser apenas no sentido de informar, de persuadir ou, ainda, no de dialogar. $\mathrm{O}$ sentido idealizado pela atividade de Relações Públicas é a via de mão dupla e a negociação ganha-ganha, isto é, o diálogo democrático em que os parceiros do processo buscam integrar seus interesses.

Kunsch (2003, p. 125), ao resumir as análises realizadas por ela sobre vários autores, pondera que:

Podemos resumir nossas considerações dizendo que, em função das características, das finalidades e dos objetivos das organizações, as relações públicas desenvolverão programas puramente institucionais ou apoiarão o marketing comercial e, ainda, a área de recursos humanos, se não for o caso de lidar com as três subáreas simultaneamente. O leque de possibilidades é muito grande. Depende só de estabelecer prioridades e de sistematizar uma ação programada e eficaz, de acordo com os interesses da organização, dos públicos e da sociedade (KUNSCH, 2003, p. 125).

\section{6 - ATIVIDADES DE RELAÇÕES PÚBLICAS.}

Ações, geralmente integradas e articuladas a programas de relações públicas que, por sua vez, são integrados às políticas da organização, constituem as atividades de relações públicas. Objetivando atingir os relacionamentos com os públicos da organização, as ações de relações publicas se utilizam de mensagens específicas para cada tipo de público. Com base nas funções de relações públicas, os autores e entidades de classe buscam inscrever as atividades de relações públicas, dentro de um contexto que engloba a missão e as políticas da organização.

Assim, em Sousa (2004, p. 15), encontra-se uma lista bastante ampla, das atividades de relações públicas, resumidas a seguir: 
- Assessoria e consultoria em comunicação e imagem - aconselhamento sobre políticas e ações a empreender por uma entidade, tendo em vista lograr atingir os seus objetivos.

- Monitoramento - observação e vigilância do meio, tendo em vista a identificação dos efeitos da comunicação da entidade sobre os seus públicos e das forças que possam afetar positiva ou negativamente a entidade.

- Investigação - pesquisa sobre cognições, atitudes e comportamentos dos públicos da entidade, geralmente usando técnicas científicas, a fim de se planificarem as estratégias e tácticas de relações públicas.

- Protocolo - zelar pelo cumprimento das formalidades e regras que visam impor ordem e bom ambiente aos eventos sociais.

- Patrocínio e mecenato - financiamento de eventos com impacto social ou de organizações e eventos que prossigam fins culturais, ambientais, filantrópicos, desportivos e similares.

- Relações com a imprensa - incorpora atividades e ações de vário teor que visam construir e gerir uma imagem positiva da entidade junto dos jornalistas e, por mediação destes, junto dos públicos atingidos pelos meios jornalísticos.

- Atividades para-jornalisticas - planejamento e elaboração de produtos de relações públicas de natureza jornalística, como jornais e boletins, vídeos institucionais, etc.

- Gestão de meios - normalmente, implica combinar a utilização adequada, no tempo certo e em função dos recursos disponíveis, de relações públicas e publicidade em meios jornalísticos, meios de comunicação interna, meios publicitários, etc.

- Assuntos públicos - intervenção das relações públicas na definição de políticas públicas da organização, com vista à sintonização desta com os interesses e expectativas dos públicos e vice-versa.

- Lobbing - relações diretas com os agentes legislativos, executivos e reguladores, em nome de uma entidade, de um grupo ou de um setor.

- Resolução e gestão de conflitos - visa à identificação e resolução de conflitos (pessoais, organizacionais, etc.) que possam afetar a organização e cuja resolução passe pela comunicação.

- Relações financeiras - área das relações públicas que visa captar investimentos ou donativos e manter a confiança de investidores, credores ou doadores. Esta área das 
relações públicas também se conhece, nas empresas por "relações com acionistas" ou "relações com investidores."

- Relações empresariais - relacionamento da organização, com outras organizações, com empresários, com sindicatos e associações, etc.

- Relações com colaboradores - área vital das relações públicas direcionada essencialmente para o público interno, com vários fins em vista: criação e gestão de uma imagem positiva da organização junto desses públicos; motivação e aumento da produtividade.

- Relações com o público-externo em geral - área vasta das relações públicas que visa à divulgação da entidade, seus produtos ou serviços e a sintonização da entidade com o seu público externo e misto e vice-versa.

- Sinalética e adaptação do meio físico - sinalização correta das instalações onde funciona a organização e adequação das mesmas aos colaboradores e visitantes, não ignorando as pessoas portadoras de deficiência.

- Identificação visual - construção e eventuais reformulações de um sistema de identificação visual ancorado num logotipo e escolha dos suportes em que ele figurará constantemente.

- Relações inter-culturais e multiculturais - o campo das relações multiculturais tem-se tornado de crescente importância para as relações públicas devido à globalização, que trouxe consigo novos fluxos migratórios.

- Comunicação de marketing (marketing mix comunicacional) - combinação de ações desenhadas para vender um produto, um líder, um serviço ou uma idéia, de acordo com os resultados de pesquisas científicas sobre o perfil do público-alvo.

- Comunicação de crise - setor específico das relações públicas que se ocupa da prevenção de crises e do planejamento da resposta comunicacional a dar a situações de crise.

- Percebe-se que as atividades de relações públicas muitas vezes se sobrepõem, formando assim um rol pouco variável. Cabe a cada profissional, após identificar com clareza as características da organização onde atua, e assim conjugar elementos de sua especialidade para obter os resultados desejados.

Complementa-se a abrangência das relações públicas com Kunsch (2003, p. 128), que dimensiona a prática das atividades. 
No dia-a-dia, o profissional de relações públicas realiza, em síntese, as seguintes atividades: serviço de consultoria de alto nível; planejamento, organização e execução de eventos; relações com a mídia/assessoria de imprensa; coordenação de publicações institucionais - jornais, revistas, livros especiais, relatórios, boletins etc.; pesquisa de opinião pública; pesquisa institucional; auditoria de opinião; auditoria de imagem; auditoria de comunicação organizacional; organização e acompanhamento de visitas programadas; edição e distribuição de publicações institucionais; realização de projetos culturais; programas especiais para o público interno; projetos e ações sociais - balanço social, relatórios de responsabilidade social; serviço de atendimento ao consumidor; atividades em apoio a marketing; propaganda institucional; organização de mailing e relações de públicos estratégicos; marketing político; marketing de relacionamento; marketing cultural; marketing social.

Identifica-se assim, a amplitude do mercado onde o profissional de relações públicas pode atuar. Em organizações, localizado nos departamentos de comunicação ou afins, em assessorias independentes de comunicação, como prestador de serviço, ou em nível de consultoria e assessoria. As novas formas de relacionamentos que surgem a cada dia fazem com que o mercado, o Estado e a sociedade civil busquem redefinir o papel de cada um. Nesta sociedade, o desenvolvimento das relações públicas está cada vez mais especializado e se criam perspectivas de atuação em todas as frentes. O turismo/hotelaria é um campo promissor para o desenvolvimento das atividades de relações públicas o que será visto no próximo capitulo. 


\section{CAPITULO IV - TURISMO E TURISTA NO BRASIL: PEQUENO RETRATO.}

\section{1 - TURISMO NO BRASIL}

Num primeiro momento, neste capítulo, busca-se entender o que é o turismo e quais são as suas características, traçando um panorama do turismo no Brasil, sem se aprofundar, apenas para demarcar sua evolução e quais são os programas oficiais do turismo brasileiro, dando ênfase ao turismo nordestino. Procura-se compreender o papel do turista, seu potencial e suas características.

Um fenômeno comum nos dias de hoje, o turismo pode ser explicado por meio de literatura de raízes longínquas. Porém, não é objetivo desta pesquisa trazer à tona a idéia dos que recorrem à Bíblia para encontrar as raízes da viagem. Apenas para registro, a passagem bíblica a que se reportam e estudam vários autores é a de que alguns homens foram enviados à terra de Canaã em busca de informações demográficas, agrícolas, topográficas e outras, referentes àquele país, ou seja, a ação de viajar em busca de conhecimento, corresponde à palavra hebraica tur.

$\mathrm{Na}$ medida em que durante os tempos se foram conjugando os verbos - comer, dormir, comprar e conhecer -, o turismo deixou de ser uma atividade para amadores, exigindo-se mais qualidade, mais profissionalismo, mais tecnologia e mais produtividade daqueles que recebem. A evolução do turismo e os seus conceitos foram evoluindo com o seu próprio desenvolvimento, que teve na pós-segunda guerra seu período de crescimento, considerado como marco do turismo estruturado.

Assim como qualquer outra atividade econômica, o turismo possui características especiais que o tornam único e específico. Entre essas características, Schuch (2001, p. 37), destaca "a rigidez dos componentes do fornecimento (1); a instabilidade da procura (2); a sensibilidade da procura (3); a variação da procura de acordo com a estação (4); e a concorrência entre destinos e a distribuição (5)". Este último faz com que o turismo seja diferente dos demais produtos oferecidos na era industrial.

No turismo, o consumidor compra um produto com "várias etiquetas" (de todas as organizações que intervêm no pacote do produto). Isto faz com que o turista veja a qualidade do conjunto e não das partes. Portanto, deve-se estabelecer entre as partes envolvidas no sistema do turismo consenso no estabelecimento de estratégias e objetivos.

Esta visão sobre o turismo como fator econômico possui uma grande quantidade de obras, que focalizam seus estudos na esfera dos impactos provocados pelo turismo, 
principalmente, os impactos positivos. Segundo Lemos (2001, p. 71), os impactos econômicos com maior incidência são:

- na balança de pagamentos: um efeito comercial (gastos dos turistas que funcionam como uma exportação invisível, na qual os consumidores e não as mercadorias se deslocam) e um efeito de redistribuição de renda (o excedente de renda se transfere de um local para o outro);

- nos efeitos globais: sobre a estratégia de desenvolvimento da economia da localidade como sua capacidade de financiar déficits, capacidade de dinamizar, de reduzir a dependência tecnológica via intercâmbio (congressos);

- nos setores produtivos: (aumento da produção e do emprego);

- no setor público: (gastos e receitas tributárias);

- na estabilidade de preços: (inflação e especulação imobiliária);

- na equidade do sistema: (melhoria da distribuição de renda, integração social, transferências de impostos - o turista paga impostos que geram - benefícios aos cidadãos);

- na ordenação do território:

- efeitos indiretos: formação do profissional, intercâmbio social e cultural;

- estímulo aos investimentos: os gastos dos turistas mobilizam o setor e os serviços periféricos como o imobiliário e o comércio;

- efeito difusor: na medida em que a renda gerada vai se propagar além das fronteiras dos municípios;

- efeito multiplicador de renda: o impacto inicial dos gastos funciona como um catalisador de demanda e de emprego.

A globalização também trouxe vários benefícios para o turismo, disponibilizando uma ampla acessibilidade aos produtos, crescimento de novas destinações, aumento do turismo de negócios, aumento de instalações e dos serviços turísticos, conforme constata-se em, Beni:

Considerando os efeitos ampliadores da globalização, surgiram estratégias globais para identificar, desenvolver e comercializar o turismo de base local em clusters e redes corporativas de empresas, como, por exemplo, operadoras turísticas, empresas de transporte aéreo, cadeias hoteleiras e um pool promocional de pequenas e médias empresas agregadas à cadeia produtiva do turismo (BENI, 2003, p. 28). 
Beni acrescenta que é importante destacar que a mudança estrutural em todos os setores do turismo foi induzida pela dinâmica interna de cada um desses setores nos diferentes países, nas diferentes economias, nas diferentes vocações turísticas regionais e nas diversas motivações políticas e sociais dos agentes institucionais públicos e privados, como também nos atores sociais e na participação da população das comunidades envolvidas.

Entende-se, apesar disso, que o turismo, embora mundializado, continua sendo uma atividade concentrada em algumas regiões e localizações. Porém, não se pode negar a tendência do turismo em se globalizar quando se perceber os tipos de turismo que foram aparecendo no decorrer dos tempos como, por exemplo, o turismo ecológico, o turismo de aventura, o turismo rural, o turismo endógeno, o turismo de negócios, entre outros. A globalização proporcionou para diversas regiões a perspectiva de expansão e fortalecimento do mercado turístico internacional. Porém, para que os países em desenvolvimento ofereçam produtos turísticos em condições de competitividade com os locais já estabelecidos como turísticos, é necessário que desenvolvam políticas de turismo com base nas recomendações de organizações mundiais voltadas para o comércio e para o desenvolvimento sustentável.

Para Netto e Trigo (2003, p. 28), são três os fatores fundamentais para o desenvolvimento do turismo em um país ou região:

Os três fatores fundamentais para o desenvolvimento do turismo em um país
ou região são estabilidades política, social e econômica. Se houver a
inexistência de um desses fatores ainda é possível o desenvolvimento ou a
manutenção do fluxo turístico, mas se dois desses fatores estiverem
comprometidos, certamente o turismo sofrerá um decréscimo acentuado.
Porém, há um fator isolado que compromete definitivamente o setor de
viagem e turismo: o terrorismo. (NETTO e TRIGO, 2003, p. 28).

A comunicação global, feita por meio de instrumentos como a internet, a televisão a cabo, e ainda, as publicações especializadas em turismo faz com que novos viajantes se interessem em conhecer novos destinos, não se restringindo mais a realizar a mesma viagem, ao mesmo local, na mesma época, conforme destaca Mário Beni, ao discorrer que "o mundo está penetrando no alvorecer de um novo turismo, uma era de viagens em escala maciça, verdadeiramente global. Pessoas das mais variadas classes sociais e de todos os países viajam para todos os quadrantes do planeta”.

Assim, percebe-se que o turismo não é apenas um fato gerador de renda, e sim um fenômeno que deve ser entendido a partir de inúmeras facetas que envolvem o existir humano.

Portanto, os benefícios ou malefícios sociais do turismo devem ser estudados proporcionando uma análise mais profunda e abrangente do seu desenvolvimento. O turismo, 
um grande negócio global, é também prazer, satisfação humana, é um convite para o conhecimento de culturas diferentes, é a possibilidade de explorar o planeta, é o imaginário das pessoas que expressa sentimentos os mais variados possíveis.

Identifica-se, desta forma, a quantidade de elementos e fatores que o turismo engloba: humanos, sociais, ambientais, econômicos, culturais, etc. Diante disto, faz-se necessário entender o que é o turista e qual o seu papel ao praticar o turismo. Nos dicionários o turista é definido como pessoa que faz turismo, porém, para os estudiosos, esta definição é muito limitada.

Teoricamente o turista seria um viajante que procura saciar as expectativas que o levaram a realizar aquela viagem. Estas expectativas são as mais distintas possíveis, variando de pessoa para pessoa. Espera-se que o turista, ao buscar determinada localidade, enquadre-se ao local visitado, penetrando e respeitando a cultura e os hábitos cotidianos locais.

A compreensão do que é turista possui várias abordagens; uma delas feita por Burkart e Medlik em 1981, resumidas, a seguir:

a - são pessoas que realizam uma viagem a determinado lugar onde pretendem passar algum tempo;

b - buscam um lugar diferente do seu local normal de trabalho e moradia, assim, suas atividades são diferentes das atividades das populações para onde estão indo;

c - a viagem é temporária, e sua intenção é retornar para casa após algum tempo;

d - não objetiva fixar residência nem ter emprego remunerado no lugar onde está realizando a visita. O turista se desloca de livre vontade, o período é limitado, a viagem é para local fora de sua residência. É a pessoa que viaja em busca de lazer, diversão, descanso.

Numa ampliação do termo turista, Souza e Correa, afirmam que turista

É toda pessoa, sem distinção de raça, sexo, língua e religião, que ingresse no território de um Estado contratante diverso daquele em que tem residência habitual e nele permaneça pelo prazo mínimo de 24 horas e máximo de seis meses, no transcorrer de um período de 12 meses, com finalidade de turismo, recreio, esporte, saúde, motivos familiares, estudos, peregrinações religiosas ou negócios, mas sem propósito de imigração (SOUZA E CORREA, 2000, p. 152).

Assim, o turista é sempre identificado, por estudiosos no assunto, de acordo com o tipo de turismo que está praticando, se de lazer ou de negócios. Qualquer que seja o tipo de turismo e, consequientemente o tipo de turista ele é visto como um consumidor que procura acima de tudo por serviços e estruturas que contrastem com o seu cotidiano.

Em Meireles, percebe-se o turista como: 
uma criatura diferente, cheia de exigências, que, antes de ver os panoramas, quer experimentar os colchões, antes de se extasiar diante de uma igreja ou de um museu, quer ver a cara do copeiro, e cujas necessidades numerosíssimas não há profeta do Aleijadinho que seja capaz de prever (MEIRELES, 1999, p. 71).

Complementa a autora:

Ora, uma das coisas que o turista deseja (porque o turista é desajeitado mas bem intencionado) é entrar em contato com a terra e com o povo. O turista quer saber como é o nosso feijão e o nosso vatapá, e o que é um abacaxi (ai de nós, como sabemos!) e uma jaca, e as diferenças que existem entre uma cobra e um sabiá. De modo que não se pode sempre levar e trazer o turista pelos ares, dando-lhe de comer em caixinhas de papelão, e mostrando-lhe as estradas de dois mil metros de altura... Não, nesse ponto, eu defendo o turista: ele merece ser bem tratado; e se o chamamos para lhe mostrar alguma coisa, devemos ser honestos e verdadeiros, pois o dinheirinho que ele gasta nessas coisas, pode não ser honesto (que sei eu!), mas não é falso (MEIRELES, 1999, p. 71).

Independente do tipo de turismo que é praticado entende-se que o turista e os autóctones encontram-se em situações opostas e diferentes. A necessidade de trabalho de um é a liberdade e o lazer do outro. Compreende-se que o ambiente de férias choca-se com o ambiente de trabalho, a necessidade de repouso com a necessidade de sobrevivência. Esta relação, turista \& autóctones, gera vários tipos de sentimentos e de atitudes de ambas as partes. De um lado, o turista que está num ambiente estranho ao seu habitat, busca conforto e segurança, do outro, os que vivem do turismo no seu cotidiano corriqueiro. Desta forma, a distância ou a aproximação dependerá da boa vontade dos dois.

Registra-se que, para os autóctones, acontecem sempre as mesmas excursões, as mesmas festas, nas mesmas datas e, conseqüentemente, as mesmas indagações. Para o turista tudo é novidade. Para o autóctone, é a repetição do seu dia-a-dia.

Em Bouhdiba, encontra-se uma crítica ao turista:

Na realidade, ele (o turista) não vem nem pelo país, nem pelos habitantes. É um passante que, na realidade, não vê nada. No fundo, ele procura apenas a confirmação de sua opinião preconcebida, isto é, ele deseja dispor do conforto a que está acostumado a reconhecer, na realidade, a imagem falsa que construiu sobre o país receptor (BOUHDIBA, 1981, p. 7).

Outro autor, Bugnicourt, vê no turista um ser egocêntrico que busca sempre satisfazer suas necessidades de lazer e prazer, demonstrando sua superioridade cultural e intelectual. 
Não é um país que eles visitam, é o fantasma de um país, em que toda a atenção se volta apenas para o que é estranho, fora do comum, bizarro, imponente ou minúsculo. O turista que atravessa correndo os lugares e sobrevoa rapidamente as regiões, vive apenas aquilo que esperava. Agindo dessa forma ele não pode resistir à tentação do etnocentrismo, isto é, do nacionalismo, proclamando a superioridade universal da própria cultura (BUGNICOURT, 1983, p. 31).

Entende-se que a generalização não deve ser aplicada a este assunto, uma vez que não existem dados completos sobre o mesmo na literatura pesquisada, porém, estudiosos afirmam que se está longe de um verdadeiro encontro entre os turistas e os autóctones. Podese afirmar que o turista é resultado de um fenômeno social, político, econômico ou cultural, que por algum motivo deixa seu ambiente de moradia e trabalho, utilizando-se de um meio de transporte para deslocar-se para determinado local onde fará uso de um meio de hospedagem, permanecendo um período superior a 24 horas nessa localidade. Nas análises recentes sobre o turista e suas características, a grande maioria dos autores pesquisados, trata o turista como cliente, numa visão do homem como consumidor de um produto ou serviço. Desta forma, aspectos sobre o consumidor de turismo são encontrados em Crisóstomo, que identifica os motivos para se realizar uma viagem:

No mundo iniciou-se um estudo para identificar os motivos que levam as pessoas a viajar. As pesquisas apontavam que viajar era sinônimo de prestígio social (status) na década de 1950. Atualmente, o prestígio, ainda social, caracteriza a motivação pelas viagens turísticas, mas observa-se que prevalece a intenção de fuga do cotidiano. As motivações de viagens turísticas podem ser caracterizadas em dois tipos:

Motivação de sair:

- fugir dos problemas do cotidiano;

- fugir da rotina;

- descansar;

- fugir do ambiente poluído.

Motivação de ir:

- diversão;

- interesses culturais;

- crescimento curricular ou completar estudos;

- novidades em feiras ou exposições;

- interesse por novos lugares, novidades;

- aventuras;

- convivência com a natureza (CRISÓSTOMO, 2004, p. 73).

A sociedade atual vive uma mobilidade frenética, aproveitando todas as oportunidades para viajar e fugir do cotidiano com a maior freqüência possível. Não importa se são finais de semanas, feriados ou longas viagens de férias. A necessidade de viajar para fugir do dia-a-dia está cada vez mais evidente, tornando-se perceptível ao se verificar que ano após ano, finais de semana após finais de semana, milhões de pessoas enfrentam 
congestionamentos em estradas, aeroportos e rodoviárias. Nos locais turísticos formam-se filas nos restaurantes e nas lojas. As praias estão cada vez mais cheias.

A necessidade de viajar para fugir das atividades corriqueiras está clara em Krippendorf.

\begin{abstract}
Nos nossos dias, a necessidade de viajar é, sobretudo, criada pela sociedade e marcada pelo cotidiano. As pessoas viajam porque não se sentem mais à vontade onde se encontram, seja nos locais de trabalho, seja onde moram. Sentem necessidade urgente de se desfazer temporariamente da rotina massificante do dia-a-dia do trabalho, da moradia e do lazer, a fim de estar em condições de retomá-la ao regressarem. O trabalho é cada vez mais mecanizado, compartimentado e determinado fora da esfera de sua vontade. ...Para encontrarmos uma compreensão para tudo o que nos falta no cotidiano, para tudo o que desapareceu, viajamos, desejamos liberar-nos da dependência social, desligar-nos e refazer as energias, desfrutar da independência e da livre disposição do próprio ser, entabular contatos, descansar, viver a liberdade e procurar um pouco de felicidade (KRIPPENDORF, 2001, p. 14).
\end{abstract}

Entende-se que se viaja para sobreviver, para recarregar as energias e voltar ao afazeres do cotidiano. Para isso, a sociedade coloca à disposição a indústria do lazer, que a cada dia se apodera mais do tempo livre dos cidadãos. Nas viagens, o turista consome o clima, a natureza, a cultura do local visitado, torna-se mais experiente a cada dia e com isso torna-se mais exigente na escolha do destino e nas atividades que gostaria de desenvolver. Aliam-se a isto as variáveis, culturais, econômicas e sociais do contexto nas quais as pessoas vivem.

As razões para viajar são as mais variadas possíveis, segundo uma pesquisa realizada em 1985, pelo Studienkreis für Tourismus, passando da necessidade de relaxar pela busca do ar puro, fuga do mau tempo, dedicação a hobbies, cuidar da saúde e outros.

A partir dos anos 60, quando surgiram os primeiros estudos dobre a psicologia do turismo, a motivação para a realização das viagens pouco se alterou. Só a partir dos anos 70 uma leve tendência para a realização de férias ativas foi sentida nas pesquisas. Atualmente, o desejo de não fazer nada, de dormir, está cedendo lugar para os desejos de encontrar pessoas, brincar, divertir-se, praticar hobbies, etc. Quanto à motivação principal, isto é, à higiene psíquica, permanece no topo dos motivos das viagens. Estas informações são obtidas por meio de pesquisas realizadas por entidades de turismo e hotelaria com o objetivo de se preparar para receber o turista melhor.

$\mathrm{Na}$ literatura sobre turismo, são várias as teses que buscam explicar os motivos que levam o homem a viajar cada vez mais. Segundo Krippendorf (2001, p. 46), a verdade pode não se encontrar em uma ou outra tese e sim na mistura das diferentes interpretações. $\mathrm{O}$ autor 
discute algumas das teses que a literatura sobre turismo propõe o que vale a pena ser registrado.

Viajar é descansar, refazer-se - esta proposta discute a viagem como uma válvula de escape para os problemas cotidianos. O viajante refaz-se para voltar ao seu dia-a-dia. A proposta é baseada a necessidade do homem de curar as doenças modernas, surgidas principalmente após a Segunda Guerra Mundial.

Viajar é compensar e se integrar socialmente - aqui o lazer é visto como uma "droga" aprovada pela sociedade, onde o turista pode contrabalançar seus déficits e privações. É a necessidade da socialização do ser humano. Viajar é fugir - a mais difundida de todas as teses coloca o turismo como a saída para os problemas que o ser humano encontra dentro de si. Viajar é comunicar-se - em contrapartida à ausência das relações interpessoais vividas no diaa-dia. Esta tese defende que o turista deseja estabelecer contato e conhecer outras pessoas. Viajar é alargar o próprio horizonte - as necessidades de se conhecer novos hábitos e costumes são defendidas nesta tese.

Viajar é ser livre e independente - é a libertação das coerções que sofremos no nosso cotidiano, é o dispor de si mesmo. O turista não está submetido às mesmas ordens, regras e obrigações diárias. Para o pesquisador em turismo e teólogo alemão Paul Rieger, as férias constituem, talvez, o último baluarte invicto da liberdade humana da nossa sociedade.

Viajar é partir para a descoberta de si mesmo - o turista dispõe de tempo para cuidar de si, do seu eu, para se conhecer, descobrir sua harmonia interior. Viajar é ser feliz - ao se tornar livre das tensões e coerções do seu cotidiano o turista experimenta a liberdade ocorrendo assim o estado da felicidade.

A lista poderia se prolongar por todos os motivos que levam o homem a viajar, porém, é importante entender que o próprio turista é um ser complexo, o que torna difícil classificá-lo. As motivações das viagens perpassam uma percepção difusa que leva as conjecturas, no entanto, sem esclarecer o substancial. Krippendorf, enfatiza:

Pouco importa para onde se vai, desde que se afaste do cotidiano, que se possa desligar, mudar de ambiente. Nesse sentido, os locais em si não importam para a maioria dos turistas. O principal é que haja neve para esquiar, sol para bronzear, mar onde se banhar e oportunidades de congraçamento e distrações. O fato de "ir ao encontro de", o desejo de descobrir, de ir conscientemente ao encontro de outros seres humanos, outras regiões e culturas, assim como a introspecção, exerce uma função apenas acessória. O egocentrismo, contudo, é onipresente, ou quase. Não se é mais aquele que recebe instruções, mas aquele que as dá, e com a intenção de aproveitar esta oportunidade ao máximo (KRIPPENDORF, 2001, p. 51). 
O turismo é mais que simplesmente uma viagem, é um campo de atividade profissional, um importante fator de desenvolvimento sócio, cultural e econômico, em escala nacional e internacional.

Identifica-se, assim, a complexidade do turismo, que ao ser conceituado é visto sob vários enfoques, caracterizando diversas linhas de pensamentos. Procura-se entender as diversas definições de turismo com base na literatura utilizada e nas definições elaboradas pelos órgãos oficiais do setor.

A Organização Mundial do Turismo, OMT, define turismo como "as atividades que as pessoas realizam durante suas viagens e permanência em lugares distintos dos que vivem, por um período de tempo inferior a um ano consecutivo, com fins de lazer, negócios e outros".

Nielsen, assinala que o turismo tem muitas abordagens, dentre as quais, as seis mais importantes são:

Definião econômica - ao se encarar o turismo como uma atividade econômica, ela é reconhecida, principalmente, como uma outra indústria qualquer.

Definição técnica - planejadores da área de turismo apresentam diferentes interpretações sobre turismo, de acordo com suas necessidades e orientação individuais. Assim sendo, a abordagem utilizada por eles para definir turismo refletirá qualidades técnicas mais específicas.

Definição exprerimental - esta definição abrange adequadamente um elemento subjacente de escapismo, o conceito de fugir da confusa rotina diária a fim de expressar algum tipo de fantasia. $\mathrm{O}$ bem-estar e $\mathrm{o}$ desenvolvimento emocional é inerente a essa definição e merece uma análise mais profunda.

Definição psicológica - os benefícios psicológicos do turismo, à medida que estão associados a viagens de férias, também podem estar vinculados aos fatores determinantes da motivação e da demanda econômica por viagens.

Definição holística - esta definição bastante geral sobre turismo e viagens em vários níveis, incluindo o objetivo e os meios de viagem, duração pretendida, variação de preços, estilo de acomodação e tipo de turismo (cultural, de aventura, viagens de um dia e assim por diante). Ela fornece detalhes e abrangência suficientes. Não se refere especificamente ao lado empresarial do turismo, mas oferece uma descrição útil para introduzir um recém chegado ao estudo da área.

Definição de marketing/comunicação - na tentativa de transmitir o conceito de turismo a múltiplos usuários(estudantes, profissionais, acadêmicos, empresas, governos e mídia), uma definição de mercado ou comunicação pode ser a melhor maneira de compreender o turismo como um ato ou uma intenção (NIELSEN, 2002, p. 12).

Em Crisóstomo (2004, p. 311), encontra-se um conceito de turismo dentro de uma abordagem que caracteriza tempo e distância, na medida em que ele afirma que "a soma de relações e de serviços resultante de um câmbio de residência temporário e voluntário 
motivado por razões alheias a negócios ou profissionais". Assim, deslocamento de uma ou mais pessoas para uma localidade dista mais de $100 \mathrm{~km}$ e por um período acima de 24 horas e inferior a 180 dias sem exercer atividade remunerada neste local. Uma estada de uma ou mais noites em feriados, visitas a amigos ou parentes, conferências de negócio ou alguma outra finalidade, exceto coisas como estada para instrução ou ainda emprego semipermanente.

Numa visão voltada para a sociedade atual, onde a finalidade é a negociação, encontra-se em Rose (2002, p. 01), uma definição para o turismo como produto, vista por meio de uma visão que tem como sustentação o marketing, uma vez que para ela "o turismo é uma atividade econômica pertencente ao setor terciário e que consiste em um conjunto de serviços que se vende ao turista". Os referidos serviços estão necessariamente interrelacionados de tal forma que a ausência de um deles dificulta e até inviabiliza a venda ou prestação de todos os outros; possuem peculiaridades rigidamente determinadas para as quais se traslada o turista, ainda que a comercialização possa realizar-se no local de produção ou fora dele, ou seja, no ponto de origem da demanda. A diferença marcante é que na atividade turística não se realiza uma distribuição física do produto, pois é o consumidor que se desloca até a fonte de produção.

O turismo é um fenômeno multicultural, onde as relações interpessoais estão sempre presentes. Considerado uma indústria da pós-modernidade, o turismo tem a capacidade de apresentar o estranho como um produto que não ameaça e que é passível de ser desfrutado. $\mathrm{O}$ movimento que as pessoas fazem em território estranho e a possibilidade de provar a singularidade alheia faz com as viagens tornem-se um fenômeno excitante, onde o visitante está sempre em busca da diferença. Assim, entende-se que o turismo é também um fenômeno comunicacional dos mais poderosos desta época que, além de utilizar as mais modernas ferramentas da comunicação, o face-a-face, produz um antídoto à homogeneização cultural do mundo.

Nielsen, desenvolve uma definição de turismo dentro de uma visão comunicacional, demonstrando a força desta indústria:

Como nenhuma outra indústria, o turismo é a indústria da pós-modernidade. Sua natureza simbólica demanda um rico acervo de signos Made in dispostos à descoberta e à revelação (encantamento). Os mass media embalam o movimento excitando suas virtudes. $\mathrm{E}$ os grupos culturais aprendem a domar o olhar do visitante incorporando seus mundos simbólicos à rota. Um encontro de emissores falantes e receptores viajantes, permeado de cenários, arquitetura, religião, culinária, arqueologia e tudo o mais capaz de falar sobre o espaço sob observação.

E antes que tal diálogo torne-se extenuante e exceda os limites do surfar sobre as ondas, entre sacolejos e sobressaltos, volta-se para casa. Por isso, o 
turismo é mágico e funciona. É excitante, é rápido, atende às necessidades e é de fácil digestão (NIELSEN, 2002, p. 79).

Percebe-se, a partir das definições de turismo, que o traslado e a estada são imprescindíveis para que o mesmo aconteça, gerando assim, relações que levam a fenômenos sociais, econômicos, políticos, culturais e até jurídicos. É necessário, porém, o planejamento de todas as atividades, bens e serviços, que serão oferecidos ao turista. Esse quadro é extremamente importante para a geração de mão-de-obra especializada, ampliando, consecutivamente, a quantidade de empregos. As viagens por motivos de negócios, religião, visitas a amigos, eventos esportivos, conferências, além das viagens de férias e lazer, fez com que o turismo, nos últimos anos, seja visto como um dos setores sócio-econômicos mais significativos do mundo. Segundo a $\mathrm{OMT}^{1}$, em seus estudos para o crescimento anual, projetado para o período de 1995 a 2020, o turismo doméstico atingirá seu teto máximo em relação à proporção de suas populações, e este crescimento deverá ocorrer em países de economia emergente, localizados na Ásia, Oriente Médio, África e América Latina.

Ainda segundo este estudo, os principais fatores que deverão influenciar o turismo até 2020 são: econômicos (crescimento de forma moderada); teconológicos (desenvolviemnto dos transportes e da comunicação); políticos (obstáculos e procedimentos legais serão removidos); demográficos (aumento da migração para os países do norte); globalização (crescimento do poder da economia internacional); localização (grupos étnicos, religiosos e outros, serão reconhecidos); consciência socioambiental ( questões ambientais, sociais e culturais serão mais respeitadas); negócios (aumento dos nichos de mercados) e outros.

Beni, faz uma análise, com base nos estudos da OMT, sobre as megatendências do turismo nos próximos vinte anos, e destaca:

Globalização do turismo versus valorização local;

Alta tecnologia influenciando decissivamente a escolha do destino e a distribuição dos fluxos turísticos;

Viagens de férias com duração mais curta em diferentes épocas do ano, com ênfase nas facilidades e na aceleração do processo de viagem;

Incremento nas viagens de longa distância;

Polarização das preferências dos turistas no conforto básico e na aventura orientada;

a complexidade do mundo atual desafia as formas e propostas de espaço, instalações, equipamentos e serviços dos empreendimentos turísticos, notadamente os de hospedagem, para atender a um consumidor global, com relacionamento internacionalizado e fluente em três línguas, no mínimo a tarefa de tentar entender este relacionamento, para antecipar as necessidades e preferências e corresponder à expectativa dos clientes, é enorme e, para muitos, parece ser impossível;

\footnotetext{
${ }^{1}$ Organização Mundial do Turismo
} 
Turista do "mundo-encolhido" mais turismo para "lugares de trilha batida" e o advento do turismo de observação e a pouca distância;

Destino como "acessório de moda" - nível de fidelidade ao destino turístico variando conforme os gostos da demanda;

Desenvolvimento de produtos visando a atingir novos mercados de consumo, como ecologia, ambiente rural, aventura e novos desafios para aumentar a adrenalina, orientado para uma ou mais combinações dos três entretenimento, excitação e educação;

Destinos com ênfase na sua "imagem" enquanto pré-requisito para diversificação e expansão do efeito diferencial e da atratividade;

Todos à caça do turista asiático;

Crescimento do impacto do consumidor que participa de campanha em favor do desenvolvimento sustentável;

Acirramento do antagonismo no consumidor ambientalmente consciente diante do desejo da viagem consumista e massificada (BENI, 2003, p. 42).

O estudo ainda conclui que as viagens serão mais rápidas, o avião será o meio de transporte preferido para viagens longas, o conforto será mais exigido dos meios de hospedagem. Dentro deste contexto, o Brasil coloca-se, segundo estudiosos, como um destino turístico promissor, desde que posicione-se no mercado, buscando uma visão estratégica para planejar sua logística. Segundo Trigo (2003, p. 93), o turismo brasileiro possui duas fases distintas, e está passando pela sua segunda fase de grande expansão. "A primeira fase ocorreu nos primeiros anos da década de 1970, em plena ditadura militar, quando tecnoburocratas decidiram organizar o turismo nacional como uma das panacéias milagrosas para resolver os problemas do país". Com entusiasmo pueril e demagógico, implantou-se toda uma estrutura de financiamento hoteleiro, cursos superiores e técnicos de turismo, marketing agressivo porém inócuo, e muita agitação cívica baseada na conquista do tricampeonato de futebol (1970), nas vitórias de Emérson Fittipaldi, na Fórmula 1, e na beleza das brasileiras, sempre finalistas nos então famosos concursos de Miss Universo.

Esta primeira fase não obteve êxito devido às várias crises pelo qual o mundo passava, principalmente a do petróleo e pela falta de visão dos planejadores que não se preocuparam em cuidar do meio ambiente, não deram atenção à questão da qualidade, nem à formação de profissionais da área para atuarem nos serviços necessários.

A segunda fase é a que estamos presenciando agora e, que teve início com a estabilização da democracia em meados dos anos 1990. "Pela primeira vez, em 1996, a Embratur embasou a política nacional de turismo; investimentos nacionais e estrangeiros jorraram em hotéis, parques temáticos e projetos ligados a entretenimento; a privatização das telecomunciações e de várias rodovias proporcionou melhoras na infra-estrutura". Enfatizando que houve o crescimento da formação profissional em todos os níveis (superior, 
médio e básico); novos cursos como hotelaria, gastronomia e lazer somaram-se aos cursos de turismo como formadores de profissionais qualificados; e vários Estados, Municípios, empresas privadas e ONGs compreenderam a importância do fenômeno turístico como um possível fator de desenvolvimento e inclusão social.

Os estudos sobre o turismo no Brasil vêm avançando, fazendo com que os órgãos públicos preocupem-se em colocar o turismo como instrumento indutor do desenvolvimento e da geração de empregos e rendas. De acordo com a OMT, o mercado doméstico é dez vezes maior que o turismo internacional, e no Brasil esse índice é bem maior, o que cria uma perspectiva de consolidação da atividade, melhorando a qualidade dos serviços.

O Ministério do Turismo, elaborou dentro de suas metas, o Plano Nacional de Turismo, para o período 2007/2010, que tem como objetivo principal proporcionar a expansão do mercado interno e inserir o Brasil no cenário turístico mundial, criando assim mais emprego e ocupação, sempre respeitando o meio ambiente e o patrimônio histórico e cultural do país.

Dentre os objetivos específicos, destacam-se:

- Desenvolver o produto turístico brasileiro com qualidade, contemplando nossas diversidades regionais, culturais naturais.

- Promover o turismo como um fator de inclusão social, por meio da geração de trabalho e renda e pela inclusão da atividade na pauta de consumo de todos os brasileiros.

- Fomentar a competitividade do produto turístico brasileiro nos mercados nacional e internacional e atrair divisas para o País.

- Garantir a continuidade e o fortalecimento da Política Nacional do Turismo e da gestão descentralizada. Estruturar os destinos, diversificar a oferta e dar qualidade ao produto turístico brasileiro.

- Aumentar a inserção competitiva do produto turístico no mercado nacional e internacional e proporcionar condições favoráveis ao investimento e à expansão da iniciativa privada.

Os objetivos ainda visam possibilitar o acesso aos portadores de necessidades especiais; qualificação do mercado de trabalho; incentivo ao aumento da taxa de permanência; ampliação e consolidação do sistema de informações turística; monitoramento dos impactos sociais, culturais, ambientais e implementação de estratégias relacionadas à logística de transportes. 
O turismo é considerado pela UNESCO, como um dos elementos primordiais para que a paz mundial se consolide, uma vez que o fluxo de turista e os relacionamentos entre os povos faz com que se crie sentimentos de amizade, respeito e cooperação entre países e populações.Com base neste entendimento programático, a UNESCO desenvolveu estudos turísticos para atuar nas diversidades sociológicas, ambientais, culturais e políticas em todo o mundo, orientando para a implementação de planos e programas.

O Brasil, país privilegiado pelas dimensões continentais, inexistência de vulcões, terremotos e invernos rigorosos, tem em cada uma de suas regiões a potencialidade de se ter um pólo receptor de turismo.

Segundo informações de Ministério do Turismo, os negócios do turismo no Brasil já representam 4\% do PIB, cerca de 20 milhões de dólares. Isso faz com que a expansão das atividades relacionadas ao turismo avancem e novos destinos sejam descobertos a cada dia e aproveitados como locais de potencial turístico, gerando oportunidades de trabalho, desenvolvimento local e atividades correlatas ao turismo. Estes novos locais de turismo são gerados pelas novas tendências da segmentação das modalidades turísticas, que nos últimos anos têm contribuído para o crescimento e desenvolvimento do setor, abrindo um leque de atividades secundárias. Lembra-se, porém, que o turismo pode acarretar problemas sociais, econômicos e ambientais, entre outros.

No que concerne às políticas públicas de turismo, o Ministério do Turismo elaborou o Plano Nacional de Turismo, com vigência até 2010, onde as ações foram pensadas e planejadas com vistas a atingir todo o país, por meio de megaprogramas, subdivididos em programas. A seguir faz-se um levantamento destes programas, seus objetivos e quais ações serão desencadeadas:

- Planejamento e Gestão - SNPTur, tem como objetivo a articulação entre os diversos setores, públicos e privados, para que decisões, soluções, eliminação de entraves, nas esferas federal, estadual ou municipal, sejam tomadas em conjunto. Este megaprograma tem como programas:

- Programa de Implementação e Descentralização da Política Nacional formulação e implementação de ações da Política Nacional, que são enviadas como recomendações ao Fórum Nacional de Secretários e Dirigentes Estaduais de Turismo e aos Conselhos Estaduais de Turismo.

- Programa de Avaliação e Monitoramento do Plano Nacional de Turismo acompanhamento, avaliação e proposições nos processos de planejamento e implementação. Verificação do cumprimento das metas estabelecidas. 
- Programa de Relações Internacionais - ações ligadas ao desenvolvimento das relações com outros países e suporte à participação do Brasil junto à Organização Mundial do Turismo e ao Mercosul.

- Informação e Estudos Turísticos - SNPTur, tem como objetivo pesquisar a estruturação sob a ótica da oferta e da demanda, os impactos socioeconômicos, culturais e ambientais da atividade turística. Tem como programas:

- Programa Sistema de Informação do Turismo - realização e disseminação de pesquisas sobre turismo, para formar um banco de dados com indicadores de turismo.

- Projeto Inventário da Oferta Turística - estabelecimento de uma metodologia oficial para inventário turístico do país e elaboração de uma banco de dados de abrangência nacional.

- Programa de Competitividade - avalia a oferta turística em nível nacional e internacional.

- Lojística de transporte - por ser imprescindível para a realização do turismo, o transporte tem merecido destaque nesta proposta.

- Programa de Ampliação da Malha Aérea Internacional - voltado para atrair empresas aéreas do mundo todo com o objetivo de trazer mais turistas para o Brasil.

- Programa de Integração da América do Sul - tem como objetivo integrar as companhais aéreas da América do Sul e fomentar o turismo de lazer e de negócios.

- Programa de Integração Modal nas Regiões Turísticas - mapeamento dos principais eixos turísticos rodoviários, aéreo e fluvial e melhoria da infraestrutura e dos equipamentos relacionados a postos de combustíveis, alimentação e hospedagem.

- Regionalização - objetiva incrementar a segmentação, ressaltando o artesanato, a culinária e a produção industrial de cada região do país.

○ Programa Roteiros do Brasil - foram mapeadas 200 regiões turísticas no Brasil com o objetivo de demonstrar a diversificação do país.

- Programa de Planejamento e Gestão da Regionalização - projetos desenvolvidos nas 27 Unidades Federadas com gestão regional e avaliação municipal, estadual e federal. 
○ Programa de Estruturação dos Segmentos Turísticos - estruturação dos roteiros turísticos e segmentação da oferta e da demanda.

- Programa de Apoio ao Desenvolvimento Regional do Turismo - tem como objetivo beneficiar a população residente da atividade turística. Implantação de estruturas de acordo com as necessidades de cada Estado.

- Fomento à iniciativa privada - disponibilidade de crédito para pequenos, médios e grandes negócios voltados ao turismo.

- Programa de Atração de Investimentos - compõe-se das ações de fomento e mobilização da iniciativa privada na implementação da Política Nacional de Turismo.

- Programa de Financiamento para o Turismo - crédito ao turismo e ao turista, melhorando as condições já existentes de financiamento.

- Infra-estrutura pública - execução de projetos voltados para a melhoria dos destinos turísticos.

- Programa de Articulação Interministerial para Infra-Estrutura de Apoio - prevê a melhoria da infra-estrutura por meio dos Ministérios das Cidades, Transporte, Cultura, Meio ambiente, Integração Nacional e Defesa.

- Programa de Apoio à Infra-Estrutura Turística - identifica e melhora as condições para a realização do turismo nas diversas regiões do país.

- Programa de Promoção Nacional do Turismo Brasileiro - integra atividades de propaganda, publicidade e a participação em eventos considerados importantes para agregar valor ao turismo brasileiro.

- Programa de Apoio à Comercialização Nacional - propõe atividades integradas entre operadoras, agentes, secretarias e órgãos oficiais de turismo.

- Salão do Turismo - roteiros do Brasil - evento com o objetivo de apresentar e incentivar a organização e comercialização dos roteiros turísticos do Brasil. Tem como público agentes de turismo, imprensa, pesquisadores, professores, estudantes, empresas e profissionais do setor.

- Viaja Mais Melhor Idade - tem como objetivo promover a inclusão social das pessoas acima de 60 anos, aposentados e pensionistas, proporcionando tarifas mais baixas em hospedagem, alimentação e transporte. O projeto é desenvolvido pelo Ministério do Turismo - Mtur, Associação Brasileira de Operadoras de Turismo - Braztoa e Associação Brasileira de Agências de Viagens - ABAV. 
- Vai Brasil - também desenvolvido em parceira do ABAV e Braztoa, o projeto tem como objetivo a ocupação dos destinos turísticos na baixa temporada.

- Programa de Promoção Iinternacional do Turismo Brasileiro - objetiva a promoção do turismo brasileiro e a divulgação e fixação da marca Brasil, por meio de participação em feiras e eventos de turismo. Conta ainda com ações específicas de relações públicas.

- Programa de Apoio à Comercialização Internacional - divulga e dá conhecimento de produtos turísticos brasileiros com o objetivo de ampliar a comercialização desses produtos no exterior.

Registra-se a importância que o turismo/hotelaria possui para o desenvolvimento da região Nordeste do Brasil, pelos programas específicos que são elaborados pelo governo federal para a região. Dentre eles, destaca-se o Programa de Ação para o Desenvolvimento do Turismo do Nordeste, Prodetur/NE, iniciado em 1994, com o objetivo de desenvolver e consolidar a atividade turística na região buscando eliminar as desigualdades sociais entre as diversas regiões do país. O Prodetur tem o financiamento do Banco Interamericano de Desenvolvimento que, em sua primeira etapa, investiu na melhoria e implantação de estradas, na modernização de 8 aeroportos e no saneamento básico de áreas turísticas.

$\mathrm{Na}$ sua segunda fase, o programa tem como principal objetivo melhorar a qualidade de vida da população permanente nos municípios integrantes dos Pólos de Desenvolvimento Integrado de Turismo, por meio da geração de maiores oportunidades de emprego, maior disponibilidade e qualidade dos serviços urbanos municipais e uma melhor qualidade do meio ambiente.

O programa foi elaborado de maneira que possibilita cada um dos nove Estados participantes a adaptá-los aos seus objetivos e metas, de acordo com as características locais.

A seguir, procurou-se analisar os planos turísticos de cada Estado do Nordeste, com o objetivo de evidenciar a necessidade de investimentos na área da hotelaria, uma vez que, sem exceção, os Estados buscam atrair, cada vez mais, seus visitantes.

Maranhão: O Governo do Maranhão vem investindo na área do Turismo criando, em 2000, o Plano de Desenvolvimento Integral do Turismo do Maranhão. Segundo dados da Secretaria de Estado de Turismo do Maranhão, o plano gerou uma proposta concreta de consolidação de uma política de Turismo, atividade até então pouco desenvolvida no cenário econômico estadual.

O plano prevê ações de curto, médio e longos prazos, e sua vigência de cumprimento vai até 2010, priorizando 03 eixos de ação: infra-estrutura, marketing e treinamento. O estado 
optou também por promover o Turismo cultural e ecológico, aproveitando suas manifestações populares, seu patrimônio arquitetônico e sua privilegiada condição pré-amazônica, caracterizada por uma grande variedade de ecossistemas e biodiversidade.

Por meio de pesquisa foram selecionados 05 pólos de desenvolvimento: Floresta dos Guarás, Lençóis Maranhenses, Delta das Américas, Chapadas das Mesas e Pólo dos Lagos.

Ceará: O Programa de Ação para o Desenvolvimento do Turismo no Nordeste (Prodetur), do Estado do Ceará visa a estruturar os municípios da região Costa do Sol Poente a partir de ações que contribuem para o equilíbrio entre natureza e espaços construídos. $\mathrm{O}$ programa também apóia os setores produtivos e culturais, estimulando atividades públicas e privadas, contribuindo para o fortalecimento da capacidade municipal para gestão do turismo. Dentre os objetivos principais, destacam-se: proteção e conservação dos recursos naturais e culturais; urbanização de áreas turísticas; complementação de rodovias; ampliação e implantação do sistema de esgotamento sanitário e abastecimento d'água; conscientização da população e capacitação de profissionais da área do turismo; elaboração de plano de marketing e desenvolvimento turístico.

A Secretaria de Estado de Turismo do Ceará, também elaborou ações de planejamento estratégico que visam à elaboração de estudos e pesquisas para o desenvolvimento do turismo e monitoração dos indicadores e agregados turísticos.

Paraíba: No Estado da Paraíba, o Prodetur prevê, a médio e longo prazo, a consolidação de uma política de Turismo sustentável.

Com projetos voltados para a recuperação e implementação da infra-estrutura turística, o plano busca conscientizar a população permanente da importância do Turismo para o Estado. Financia projetos de desenvolvimento industrial, recuperação e proteção do meio ambiente, transportes, obras viárias, recuperação do patrimônio histórico e melhoria e ampliação dos aeroportos.

Sergipe: A Secretaria de Estado do Turismo de Sergipe justifica que o desenvolvimento do turismo dá-se a partir de investimentos, em especial da iniciativa privada ligada ao setor hoteleiro, alimentação, lazer entretenimento, dentre outros.

Para a viabilidade desses investimentos, torna-se fundamental a oferta de infraestrutura básica, que garanta a sustentabilidade da atividade turística ao longo do tempo.

No Estado de Sergipe, o Plano Estadual de Turismo, baseado nas diretrizes do Plano Estratégico do Turismo, previu a elaboração do Programa de Infra-estrutura para o Turismo, que abrangerá todos os pólos turísticos do Estado. 
Define ainda como objetivo geral do plano a melhoria da acessibilidade, o saneamento básico e os meios de comunicação nas diversas regiões turísticas do Estado, e investimentos nas áreas de saúde e da segurança pública, como meio de melhorar a qualidade de vida da população local.

Referente às ações relacionadas à infra-estrutura com os recursos do Prodetur/SE, destinadas a suprir em parte estas necessidades, foram criados subprogramas como: Subprograma de Saneamento: ações relacionadas ao esgotamento sanitário, coleta e destino do lixo; Subprograma de Acessibilidade: pavimentação das principais vias de acesso aos destinos turísticos, dando atenção especial ao acesso de portadores de deficiência física, além do projeto de sinalização turística para todo o estado; Subprograma de Urbanização: ações de melhoria de praças e parques públicos.subprograma de Segurança Pública: criação e revitalização de Delegacias do Turista e curso de capacitação específica para o turismo para policiais.

Alagoas: O Estado de Alagoas, conhecido como "paraíso das Águas", vem evidenciando o turismo como atividade marcante, buscando dentro do seu processo de implementação o aperfeiçoamento da infra-estrutura e dos serviços turísticos. $\mathrm{O}$ estabelecimento de rotas temáticas é uma estratégia do Governo local para o desenvolvimento turístico. Foram identificadas e criadas 9 (nove) regiões de interesses turísticos, onde são fortalecidas a roteirização, a segmentação e a comercialização dos produtos. O Prodetur está inserido no Programa estadual de Turismo que tem como missão a implementação de programas que viabilizem a equidade, a inclusão, a justiça social e a preservação dos valores histórico-sociais e ambientais. Nas 9 regiões turísticas do Estado são desenvolvidos programas que têm como objetivo a parceria das Instituições públicas e privadas; a promoção de fóruns locais de debates, linhas de crédito para implantação e ampliação de empreendimentos e a melhoria da qualidade dos produtos e serviços turísticos.

Bahia: Com o objetivo de consolidar o turismo como atividade promotora da eficiência econômica, a equidade social e o respeito ao meio ambiente, a Secretaria da Cultura e Turismo, em articulação com a iniciativa privada e representantes da sociedade civil, lançou a nova Estratégia Turística do Estado 2003-2020, intitulada "Século XXI: Consolidação do Turismo".

Essa estratégia proposta para o período 2003-2020, que se apóia nos mesmos princípios que nortearam o modelo proposto em 1991, gerada no Programa Prodetur, visa direcionar as intervenções governamentais nas áreas de interesse turístico do Estado. 
O objetivo principal, de acordo com a Secretaria de Turismo da Bahia, é a promoção do desenvolvimento sustentável da atividade turística no Estado. Para tanto, foram criadas cinco estratégias macro, que são:

Estrutura Pública: Continuar fomentando o desenvolvimento do turismo no Estado, realizando ações nas áreas de planejamento, infra-estrutura básica e acompanhamento.

Gestão Municipal: Intensificar o apoio à modernização técnico-administrativa das prefeituras nos municípios turísticos, viabilizando um modelo de gestão referenciado nos princípios do desenvolvimento sustentável.

Educação para o Turismo: continuar estimulando a participação das comunidades dos núcleos receptores no processo socioeducativo, melhorando suas condições de vida e a qualidade da experiência do turista.

Integração: reforçar a necessidade de integração entre os atores envolvidos com a atividade turística, objetivando a inserção de todos em um projeto comum de desenvolvimento sustentável.

Marketing: o marketing do turismo na Bahia deverá ser liderado pelo conjunto de atores da cadeia de valor - atentando para as singularidades de cada ZT, direcionado para o mercado - orientando o desenvolvimento de estratégias prioritárias e de mix de marketing adequados a cada mercado - e fundamentado em pesquisa e planejamento - para monitorar hábitos, estilos de vida e tendências do consumidor.

Rio Grande do Norte: O Rio Grande do Norte, além de investir nas obras de infraestrutura, voltou-se também para o desenvolvimento institucional dos seus órgãos e elaboração dos Planos Diretores de Municípios considerados pólos turísticos.

Neste estado houve uma avaliação da primeira fase que detectou: aumento do fluxo turístico alcançado entre os anos de 1995 a 2001; aumento do número de empregos diretos gerados na hotelaria; oferta do número de leitos hoteleiros que em 1995 era de 12.915, passou para 26.353 em 2001, com incremento de 104\%; a receita turística do Estado que em 1995 era de US\$ 138 milhões/ano, passou para US\$ 216 milhões/ano em 2.001, com aumento real de 56\%, mesmo com a desvalorização da moeda brasileira ocorrida no período; aumento do número de vôos internacionais.

Segundo a Secretaria de Estado de Turismo, houve um grande número de investimentos privados tais como hotéis, restaurantes, equipamentos de lazer e entretenimentos, gerando-se empregos, negócios e riquezas, que são os objetivos finais a serem atingidos pelo programa. 
Piauí: Por meio de projetos voltados para a melhoria da qualidade de vida da população permanente dos pólos turísticos, o Prodetur, no Estado do Piauí vem instruindo os moradores da importância do Turismo para a região, ao mesmo tempo, que demonstra a necessidade da preservação ambiental. No Piauí, a preservação do solo caminha concomitantemente com o Turismo sustentável.

Os programas são desenvolvidos na região do Parque Nacional das Sete Cidades, Parque Ecológico da Cachoeira do Urubu e no pequeno trecho de praia do Estado que compreende a região de Paranaíba.

Pernambuco: Desenvolvido pela Secretaria de Turismo do Estado de Pernambuco, o Programa de Desenvolvimento do Turismo no Nordeste -Prodetur NE tem como objetivo melhorar a qualidade de vida da população permanente nos pólos turísticos, por meio de financiamento de infra-estrutura, contemplando ações de saneamento básico, administração de resíduos sólidos, recuperação ambiental e do patrimônio histórico e cultural, e desenvolvimento institucional dos órgãos públicos gestores da atividade.

Busca-se, com este programa, lançar as bases para o desenvolvimento organizado e contínuo da atividade turística na Região.

Dentro dos preceitos definidos pelo Prodetur II, considerando a adoção de um pólo turístico por estado, Pernambuco elegeu para integrar esta nova fase do Programa o Pólo Turístico Litoral, que recebeu a denominação de Pólo Costa dos Arrecifes.

As prioridades definidas destinam-se a incrementar o ritmo das demandas turísticas, pela consolidação do turismo no Pólo Costa dos Arrecifes, garantindo maior desempenho, competitividade e sustentabilidade do turismo, de forma a alavancar o desenvolvimento do Estado de Pernambuco, trazendo melhoria para a qualidade de vida das populações locais.

\section{2 - TIPOS DE TURISMO}

Fenômeno extremamente diferenciado, o turismo, pode ser praticado partindo-se de diversos fatores que levam as pessoas a viajar. Assim, classificam-se, para fins didáticos e de planejamento, o turismo em vários tipos. Entre eles destacam-se, segundo Menescal e Gonçalves:

Entre os fatores que geram os deslocamentos turísticos, destacam-se: as motivações ou objetivos da viagem (recreativo ou de lazer, cultural, de saúde, religioso, esportivo, de eventos), a procedência dos viajantes (turismo nacional ou internacional), o volume da demanda (turismo de massa, turismo de minorias), as formas de organização das programações turísticas 
(individual, organizado, social), a faixa etária dos viajantes (infanto-juvenil, adulto, para a terceira idade ou misto) (MENESCAL e GONÇALVES, 2006, p. 53).

Para um entendimento melhor de cada um dos tipos de turismo citado e, principalmente. para o desenvolvimento das atividades turísticas, a segmentação é de vital importância. A seguir, procura-se entender as características de cada tipo de turismo para melhor entender a complexidade da área.

Quanto às motivações ou objetivos da viagem, o turismo pode ser:

- Recreativo ou de lazer - motivado pela necessidade de relaxar, pela recuperação da capacidade física e mental, pela necessidade de diversão. É organizado em grupos com interesses específicos onde a descontração, as brincadeiras e o relaxamento acontecem mesmo durante a viagem, prolongando-se durante a hospedagem. Os públicos de interesse são a terceira idade e grupos de jovens. Os locais a serem visitados são muito variados, desde centros urbanos, praias, balneários, fazendas e montanhas.

- Turismo cultural - o contato com outros povos e outras culturas são pontos fundamentais para este tipo de turismo. Os locais visitados são os museus, monumentos artísticos, bibliotecas etc. As viagens geralmente são de curta duração e o público de interesse o mais variado.

- Turismo de saúde - as estâncias hidrominerais são os núcleos receptores deste tipo de turista. O núcleo turístico possui uma demanda estável durante todo o ano dispensando as ferramentas do marketing para sua divulgação.

- Turismo religioso - este tipo de turismo pode ser realizado individualmente ou em grupos. Seus destinos são os centros reconhecidos como místicos que envolvam fé, caridade e crença. Estas viagens também são denominadas em algumas regiões, como peregrinação ou romarias.

- Turismo esportivo - além de eventos esportivos de grande porte como olimpíadas e copa do mundo de futebol, o turismo esportivo é praticado pelos amantes da pesca, caça, pesca submarina, caminhadas.

- Turismo de eventos - É o tipo de turismo para participação em reuniões científicas, como congresso e seminário, e para participação em feiras e exposições.

- Turismo técnico - pessoas que se deslocam para conhecerem instalações de empresas para adquirirem conhecimentos sobre novas tecnologias.

- Turismo gay - dados fornecidos pela OMT confirma que cerca de $10 \%$ da população mundial pertence a esse segmento e demonstram que gastos efetuados por esse tipo de 
clientela são considerados acima da média de gastos individuais. Como exemplo, citase a Parada Gay de São Paulo que hoje reúne cerca de 3 milhões de pessoas por ano.

- Turismo de cruzeiros marítimos - há alguns anos privilégio de pessoas ricas, hoje, as viagens em navios são acessíveis a grande parte da população. Surgiram navios com maior capacidade para passageiros, mais confortáveis e com preços bastante reduzidos.

- Turismo de negócios - praticado por executivos que viajam para participar de reuniões, visitarem fornecedores e realizarem negócios.

Turismo quanto à procedência dos viajantes:

- Nacional - praticado por viajantes dentro das fronteiras do seu país.

- Internacional - praticado por viajantes que cruzam as fronteiras do seu país.

- Quanto ao volume de demanda, são os seguintes:

- Turismo de massa - viagens programadas para roteiros muito procurados.

- Turismo de minorias - viagens realizadas para lugares pouco procurados.

- Quanto à forma de organização, tem-se:

- Turismo individual - também chamado de particular ou autofinanciado, acontece quando não existe a participação de um agente especializado em turismo, isto é, todas as providências são tomadas pelos interessados em viajar. O termo individual não se refere à quantidade de pessoas.

- Turismo organizado - quando todas as atividades turísticas programadas são de responsabilidade de agências operadoras de turismo, associações, entidades de classe, clubes etc.

- Turismo ecológico - buscam-se áreas naturais preservadas, com o objetivo de admirar ou estudar a paisagem.

- Turismo social - quando realizado com subsídios de terceiros, geralmente entidades que mantém albergues, clubes e hospedarias específicas.

Quanto à faixa etária o turismo acontece quando:

As atividades respondam aos interesses dos grupos de cada faixa etária; infantojuvenil, adulto, terceira idade ou misto. Com o passar do tempo, as exigências de uma sociedade cada vez mais democrática, a questão da oferta e da demanda, os aspectos sócio, econômicos e culturais da globalização, os tipos de turismo surgem dependendo da necessidade de cada grupo. Assim, temos ainda o turismo GLSBT. 
Percebe-se que, para qualquer tipo de turismo acontecer, são necessários os equipamentos que compõem a infra-estrutura turística, como: transporte, hotéis, rodovias e outros. Os meios de hospedagem constituem-se em um dos principais equipamentos para a viabilização do turismo em qualquer uma das suas modalidades. Os conceitos de hospedagem mudaram e evoluíram ao longo do tempo, porém, as suas raízes continuam as mesmas. Assim, para entender a hospedagem utilizada na hotelaria, torna-se indispensável uma digressão do termo hospitalidade, o que será tratado no próximo capítulo. 


\section{CAPÍTULO V - HOTELARIA, TURISMO E HOSPITALIDADE: TENDÊNCIAS MODERNAS.}

\section{1 - HOTEL E HOSPITALIDADE}

Busca-se nesta parte do trabalho identificar as características e peculiaridades do hotel como organização, ressaltando quais são seus pontos fortes e fracos. A hospitalidade, discussão também presente neste capítulo, é analisada com o propósito de delimitar os seus tipos, dando ênfase à hospitalidade comercial. Assim, entende-se que o turismo, a hospitalidade e a hotelaria são três atividades distintas, que se inter-relacionam, dependendo uma da outra para sua própria sobrevivência.

Entende-se por hotel, uma estrutura que reúne os requisitos necessários para que os hóspedes possam viver, por tempo determinado, tendo suas necessidades preenchidas. Quanto ao seu tamanho, os hotéis são classificados em grande (mais de 300 camas); médio (de 150 a 300 camas) e pequeno (menos de 150 camas). Classificam-se, ainda, quanto à localização (montanha, praia, cidade, estação termal ou termas, estrada - motéis, local de peregrinação e aeroporto); quanto à clientela (própria do país, internacional, executivos ou homens de negócios, estudantes, artistas, técnicos, grupos, idosos, turistas, famílias); referente ao período de funcionamento (aberto todo o ano - cidades, praias ou lugares de veraneio - de estação, de estação prolongada, de duas estações).

Os objetivos dos hotéis devem levar em consideração os hóspedes, os funcionários e os proprietários. Portanto, maximizar um dos três não é fórmula para a prosperidade sustentada de um empreendimento hoteleiro. Assim, a política de um hotel, deve ser estabelecida contendo o conjunto de diretrizes, as metas a serem atingidas e os meios pelos quais isso será realizado.

Medlik e Ingran, (2002, p. 32), afirmam que após definida a política geral, políticas secionais devem ser traçadas com os principais grupos que a organização se relaciona com o objetivo de englobar os princípios a serem observados nesses relacionamentos, e propõem: uma política voltada para os clientes normalmente determina o que o hotel busca fazer em termos de seus mercados e padrões de qualidade daquilo que ele oferece; inclui seu conceito de um bom negócio e sua abordagem ao preço, descontos e crédito; declara sua atitude com relação a queixas e reembolsos. Uma política voltada para os funcionários ou para a equipe aborda questões como recrutamento, seleção e treinamento, remuneração, condições de emprego, bem-estar, promoção, aposentadoria, consultoria, negociação e o tratamento de 
controvérsias. Uma política voltada para os acionistas define o que os donos podem esperar em termos de recompensas, informações e participação nos negócios, o que se espera deles. Uma política voltada para os fornecedores determina o que se espera deles com relação à qualidade das ofertas, entrega e prazos, e que tratamento cada um pode esperar do hotel.

A definição das políticas e objetivos do hotel deve ser formulada pela gerência, ouvindo os demais funcionários e devem expressar a melhor visão do negócio e das regras a serem seguidas. Assim, todos os que serão submetidos a ela devem participar de sua elaboração. Para melhor entendimento, são desejáveis que as políticas e os objetivos estivessem escritos e comunicados aos envolvidos. Objetivos e políticas mudam, portanto, políticas devem ser ajustadas sempre que houver necessidade com o objetivo de manter ou estabelecer novos relacionamentos.

A literatura pesquisada identifica que existe uma grande variedade de tipos de hotéis, que são classificados utilizando-se critérios diferentes, de autor para autor. Encontram-se referências à hotéis de luxo, resorts, comerciais, residenciais, de trânsito, palace, alto luxo e vários outros. Medlik e Ingran (2002) afirmam que cada um desses termos serve como indicação do padrão da localidade, ou de um tipo específico de hóspede que constitui o mercado de um determinado hotel. Os autores elaboram uma lista que distingue os principais tipos de hotéis, adotando critérios específicos para classificá-los.

Assim, para Medlik e Ingran (2002), de acordo com a localização, os hotéis podem estar em cidades, em lugarejos grandes ou pequenos, no interior, na costa e em resorts de montanhas ou campo. De acordo com a posição real do hotel nesta localização, ele pode estar na cidade, no centro de um lugarejo ou nos subúrbios, ao longo da praia de um resort costeiro, ao longo de rodovias. Com referência à relação com os sentidos específicos de transporte, há hotéis de beira de estrada (motéis) e motéis de grande porte, hotéis de ferrovias, hotéis de aeroportos (os termos também indicam a localização). De acordo com a finalidade da visita e com o principal motivo da estada do hóspede, os hotéis podem se tornar conhecidos como hotéis de negócios, hotéis de férias, hotéis para convenções, hotéis para turistas. E acentuam que, "onde há uma grande tendência de estadas de curta ou longa duração, essa pode ser uma característica importante do hotel, de forma que ele pode ser considerado residencial ou de trânsito" (2002, p. 32). Para eles, de acordo com a gama de instalações e serviços, um hotel pode estar aberto para hóspedes e não-hóspedes, ou pode se restringir a oferecer acomodações de pernoite e, no máximo, café da manhã aos hóspedes, e ser um "hotel garni" ou apart-hotel. O fato de o hotel ter ou não licença para a venda de bebidas alcoólicas representa uma dimensão importante dentre a gama de serviços disponíveis no hotel, e a distinção entre um 
hotel com ou sem licença é, portanto, relevante na maioria dos países ao se descrever um hotel.Não há um acordo universal com relação a como os hotéis devem ser descritos de acordo com o tamanho, mas com referência aos quartos ou à disponibilidade de camas normalmente aplicamos o termo hotel pequeno àqueles com uma pequena quantidade de cama, hotel grande àqueles com centenas de camas, e o termo hotel de médio porte àqueles que ficam no meio termo, de acordo com a estrutura hoteleira de um determinado país.

Independente dos critérios usados nos guias de hotéis e nos sistemas de classificação existentes nos diversos países, normalmente pelo menos quatro ou cinco níveis são tidos como necessários para se distinguir de modo adequado os padrões dos hotéis, havendo certa aceitação por parte dos usuários de hotéis (MEDLIK e INGRAN, 2002, p. 11-13).

Numa adaptação da obra de Carlos Beni, que destacou dois grupos de meios de hospedagem, os hoteleiros e os extra-hoteleiros, a professora Mariana Aldrigui (2007, p. 3132), elabora um quadro sobre os meios de hospedagem chamados hoteleiros, objeto deste estudo:

- Hotel-padrão (H): oferece aposentos mobiliados com banheiro privativo, para ocupação eminentemente temporária, incluindo serviço completo de alimentação, entre outros.

- Hotel de lazer (HL): possui serviços e equipamentos de lazer e de repouso em localização geográfica com destacados méritos cênico-paisagístico.

- Hotel-residência ou suíte service (HR): dispõe de unidades habitacionais constituídas de acordo com a classificação oficial e serviços de alimentação parcial, sendo o aluguel básico cobrado por uma semana completa.

- Hotel-clube (HC): oferece equipamento de recreação e lazer, próprio ou credenciado por entidades associativas ou clubes de serviço, que atende a uma clientela dirigida, com grande redução no preço de diárias.

- Hotel de saúde/Spa (HS): combina as características do hotel padrão, com instalações, serviços e equipamentos hospitalares, com atendimento médico e de enfermagem em período integral. Destina-se a pacientes em convalescença e recuperação, sob observação e/ou em intenso processo terapêutico, dispondo, também, de equipamentos destinados a tratamentos específicos de obesidade e desintoxicação, entre outros.

- Hotel-fazenda (HF): situado em propriedades rurais e antigas fazendas, com equipamentos novos ou adaptados de tradicionais edificações originais, voltado à prática de atividades recreacionais campestres e ao contato com a natureza. 
- Eco-hotel (EH): situado em florestas tropicais ou em áreas naturais protegidas, com arquitetura e estrutura construtivas, adaptadas às condições do meio ambiente no sentido de preservar a integridade da paisagem e integrar o hóspede ao primitivismo do entorno original.

- Hotel em terminal de transporte (HTT): situado próximo a terminais de transporte, destinado a alojar passageiros em trânsito, aguardando conexões.

- Lodge (L): alojamento individual isolado - equipamento comercial hoteleiro, sob a forma de chalés, cabanas e similares, destinado ao turismo termal, de caça, de pesca e de aventura.

- Motel (M): oferece apartamentos mobiliados, possuindo também serviços completos de alimentação, situado à margem das rodovias, fora das zonas urbanas e suburbanas e que dispõe de vagas de estacionamento coletivo, coberto ou descoberto, em número igual ao de unidades habitacionais.

- Timeshare: qualquer estabelecimento comercial hoteleiro, isolado ou integrante de rede hoteleira, que utiliza processo de tempo compartilhado, com venda de títulos de propriedade individuais. Garante ao sócio patrimonial o uso de alojamento, segundo uma programação previamente estabelecida.

A Associação Brasileira das Indústrias da Alimentação, ABIA, em seus estudos, analisa os perfis e as tendências do segmento de hotéis no Brasil, donde se constata:

- O segmento de maior crescimento é o da hotelaria, que possui três e quatro estrelas, identificado por suas estruturas modernas e compactas, que privilegiam o conforto, os serviços básicos, a boa localização e uma política de diária inferior a $\mathrm{R} \$ 100,00$.

- O segmento hoteleiro da categoria luxo (cinco estrelas) atende uma concentração média de $55 \%$ do turismo internacional.

- O segmento de hotéis de categoria inferior está fortemente atrelado à terceirização dos pontos de vendas de alimentos e bebidas.

- O segmento de hotéis focados na hospedagem e eventos têm praticamente um quarto de sua receita oriunda de eventos (feiras, exposições etc.).

- No segmento de hotéis de turismo, os cardápios e a gestão dos serviços de alimentos e bebidas são itens altamente relevantes para o negócio como um todo.

Diante destas constatações, afirma-se que, como atividade econômica, o hotel se enquadra no setor de prestação de serviços e, atualmente, ocupa posição bastante expressiva 
na economia brasileira. Assim, demonstra-se agora as peculiaridades e características dos serviços oferecidos pelos hotéis:

- Intangibilidade - é um serviço que não pode ser tocado, é apenas percebido pelo consumidor. Segundo Aldrigui:

ainda que seja possível tocar a cama e o travesseiro, pisar as tábuas de um casarão antigo adaptado em pousada, o que se compra efetivamente é a possibilidade de usar tudo o que está disponível em um dado período de tempo. É adicionar a isso as sensações em relação ao tratamento recebido pelos prestadores de serviços envolvidos, como o recepcionista, o garçom e a camareira, entre outros (ALDRIGUI, 2007, p. 14).

Em serviços, não é possível testar, experimentar, é preciso comprar, e estar no local para usar e avaliar. São fatores intangíveis: a decoração, o clima de hospitalidade, a cortesia, a educação, as informações, a atenção, o sentir-se em casa, o sorriso etc. Todos estes fatores estão acompanhados de alimento, bebidas, cama, móveis, que são tangíveis.

- Simultaneidade - as reservas de hospedagem, que na quase totalidade, sempre são feitas com antecedência, só ocorrerão quando o hóspede estiver no hotel, isto é, o serviço acontece somente na presença do consumidor.

- Perecibilidade - produto com oferta constante, como a hospitalidade, se não forem ocupadas num determinado período não serão adicionados à oferta do período seguinte, ou seja, sempre é necessário buscar o máximo de ocupação em todos os dias, já prevendo os efeitos da sazonalidade do turismo, que afeta o equilíbrio financeiro do hotel.

- Residualidade - o serviço após ser consumido deixa apenas a experiência, não há a possibilidade de troca no caso da insatisfação. O que vai ficar é apenas a experiência boa ou ruim. Assim, na qualidade dos serviços e na capacitação das pessoas para desenvolvê-los reside à satisfação e a possível fidelização dos clientes.

Petrochi, ressalta que:

a hotelaria é muito afetada por influências externas, tais como desempenho do sistema de turismo onde está inserida, cenários socioeconômicos da região, mudanças tecnológicas, regulamentações governamentais, alterações nos preços de insumos, qualidade nos serviços públicos da região, disponibilidade de mão-de-obra, preservação do meio natural, existência de cultura associativa, concorrências etc (PETROCHI, 2007, p. 8).

Um dos setores que mais avançam no país, segundo o Ministério do Turismo, é a hotelaria; não só no Brasil vem contribuindo para a expansão da economia, por meio de oferta 
de emprego direto em locais considerados menos favorecidos. Como qualquer outra organização, o hotel, busca as melhores ferramentas técnicas de análise de mercado para sua implantação, otimizando a vantagem competitiva. Assim, para operar, qualquer hotel necessita de planejamento que leve em consideração a análise do cenário socioeconômico e ambiental.

A implantação de um hotel ocorre de diversas formas, porém, dois grandes universos se destacam: a hotelaria de rede e a hotelaria independente. Para sua operação tanto uma como outra, recorrem a empresas de consultoria para a realização de estudos de viabilidade, que basicamente analisam os seguintes tópicos: contextualização econômica do local; localização - vantagens e desvantagens; análise do mercado concorrencial; análise comportamental da demanda e conceituação da unidade hoteleira. Segundo Bonfato (2006, p. 43), "nessa etapa, tem início o planejamento da futura unidade hoteleira, e são definidos a tipologia do hotel, número de leitos, diferenciais oferecidos, público-alvos, projeção da possível demanda e da taxa de ocupação". Em seguida, devem-se estabelecer dados estruturais e de instalação: dimensão das áreas do hotel estimativa de investimento total para o projeto, incluído desde os custos de estudos preliminares e projeto, de edificação, de equipamentos, de utensílios, de recrutamento e treinamento de pessoal, de financiamentos, até o capital de giro necessário para o início das atividades.

Para a arquiteta Wey (2001), em artigo divulgado pela $\mathrm{ABIH}$, os projetos para os hotéis devem estar inseridos dentro de um novo conceito, levando em consideração aspectos como segurança, racionalização de energia, respeito ao meio ambiente e, principalmente, a necessidade do hóspede sentir-se em casa, porém, com novos atrativos, algo inesperado e moderno. A construção deve ser moderna, atual, com formas limpas, poucas paredes, muita transparência e o luxo excessivo devem ser substituídos pelo charme e elegância. Assim, as formas devem ser puras, como quadrados, pirâmides, círculo, ambientes grandes, limpos e despoluídos, livres de peças, ou ambientes sem função. A multiplicidade de serviços deve estar presente por meio de salas de leitura, estações de videogames, computadores, jogos de cartas, bar etc. Nas questões relativas à segurança devem ser considerados itens como: hidráulica, sensores de incêndio, detectores de fumaça, autolimpeza nos serviços de ar, higiene na filtragem das águas em geral e outros.

Entende-se que o hotel deve fazer com que o hóspede sinta-se em casa, mas ao mesmo tempo proporcionar a ele uma curiosidade por detalhes inesperados. Hoje os projetos de hotéis devem contemplar a prestação de serviços diários para que o hóspede possa usufruir do bem estar e da segurança, como se estivesse em sua própria casa. 
Diante dos problemas ambientais existentes, as construções de hotéis devem levar em consideração as características de prédios inteligentes, destacando alguns aspectos como: utilização ao máximo de iluminação natural; de ventilação natural; posicionamento do prédio em relação ao sol, o que influencia na temperatura interior; aquecimento solar; automação, serviços de elevadores digitais, sensores de presença, cartões-chave. A hotelaria deve estar ligada à informática, utilizando-se de sistemas de apoio administrativo para a racionalização de custos. Os hotéis inteligentes se utilizam da automação para atender bem o hóspede, promover a comunicação necessária para que o mesmo conheça o ambiente onde está hospedado e, expandir com agilidade os serviços oferecidos.

A estrutura organizacional do hotel leva em conta o tipo de instalações, os recursos humanos e os equipamentos necessários para o seu funcionamento. Com base na Teoria Clássica da Administração, Petrocchi (2007, p. 29), elabora as funções essenciais da empresa hoteleira.

\section{FUNÇÕES ESSENCIAIS DA EMPRESA HOTELEIRA}

\begin{tabular}{|l|l|l|}
\hline Funções técnicas & Funções comerciais & Funções administrativas \\
Recepção & Vendas & Planejamento \\
Governança & Marketing & Recursos humanos \\
Reservas & Promoção & Compras \\
Alimento e bebidas & Relações públicas & Informática \\
Telefonia & Propaganda & Transporte \\
Eventos & Assessoria de imprensa & Almoxarifado \\
Entretenimento & & Serviços gerais \\
Lavanderia & & Controles operacionais \\
Serviços diversos & & \\
\hline Funções financeiras & Funções contábeis & Funções de segurança \\
Contas a receber & Contabilidade & Manutenção predial \\
Contas a pagar & Balanço patrimonial & Vigilância \\
Tesouraria & Apropriação de custos & Prevenção de incêndios \\
Fluxo de caixa & Auditoria & Preservação ambiental \\
Aplicações financeiras & Estatísticas & \\
Captação de recursos & Contas a pagar/receber & \\
Orçamentos & & \\
\hline
\end{tabular}

Quadro 3 - Funções em hotelaria.

Fonte: PETROCCHI (2007, p. 29).

A tabela acima reflete a distribuição das atribuições a serem desenvolvidas por empregados ou terceiros.

Com base na literatura consultada, e para um melhor entendimento de como funciona um hotel, acha-se necessário discorrer as funções, específicas da organização hoteleira, isto é, as funções técnicas, uma vez que as demais se aplicam a quaisquer tipos de organizações, a seguir: 
- Recepção - é o primeiro contato que o cliente tem com o serviço contratado. Portanto, a maneira como é recebido gera reação favorável ou desfavorável. Os grandes hotéis possuem gerentes de recepção, sendo que os menores, em sua grande maioria, possuem o chefe de recepção. A recepção pode ser dividida em pré-recepção, recepção e alojamento e pós-estada. A aparência impecável, as noções de relações humanas e o conhecimento de idiomas, são critérios indispensáveis ao pessoal da recepção. Marques, (2003, p. 162) lembra que:

ainda que Recepção e Gerência não seja exatamente a mesma coisa, esta seção pode e deve ser considerada como um serviço de gerência. Ela se apresenta [...], posição de órgão diretivo do hotel, tanto em relação ao cliente como em relação aos demais setores. A recepção conta com serviços anexos como faturamento, reservas etc (MARQUES, 2003, p. 162).

- Governança - compõe a maior equipe de funcionários. É responsável pela limpeza, arrumação e organização dos apartamentos e das áreas sociais. Nos apartamentos também faz o controle dos gastos com frigobar. É um setor vital para o hotel; é o departamento que se relaciona com todos os demais, principalmente com a recepção, manutenção e setor de eventos. De acordo com estudos de Laus, (2006, p.165), governança apresenta várias funções, resumidas abaixo:

- Governanta ou Governanta executiva - na maioria dos casos, é a profissional responsável pelo maior número de funcionários em comparação com os demais departamentos do hotel e responde pela administração total do departamento. Para o desempenho das funções são necessárias qualidades morais, bom condicionamento físico, senso de organização, grande capacidade de liderança e conhecimentos técnicos.

- Assistente de governança - trabalha diretamente com a governanta, dividindo tarefas e atribuições, e assume a responsabilidade pelo departamento na ausência dela.

- Atendente de governança - responsável por toda a parte burocrática do departamento, distribuição de tarefas, atendimento das solicitações feitas ao departamento e emissão de ordens de serviço para a manutenção, dentre outras. Em hotéis menores, o trabalho é realizado pela governanta.

- Supervisora de andares - responsável pelo trabalho das camareiras e liberação dos apartamentos. Em hotéis menores, atua também como assistente, sendo responsável pela supervisão de todo o departamento. 
- Camareira - responsável pelo principal produto vendido no hotel, deve zelar para que a unidade habitacional esteja impecável, a fim de que o hóspede se sinta bem e confortável no hotel. Reporta-se diretamente à governanta e, nos hotéis de maior porte, a um supervisor ou líder.

- Auxiliar de rouparia ou roupeiro - é responsável pelas roupas do hotel (enxoval e uniformes), atendimento aos diversos setores e funcionários, confecção, conserto, reparos, envio e recebimento das roupas para a lavanderia. Reporta-se diretamente à governanta ou, em estruturas maiores, a uma supervisora de rouparia ou líder.

- Reservas - É o primeiro contato do exterior com o hotel, portanto, este setor deve ter funcionário com habilidades específicas em relação ao atendimento. O funcionário de reserva tem certa autonomia e deve responder ao pedido de reserva por meio de documento, como e-mail, fax ou carta. O setor de reservas tem caráter de gerência. A reserva de um quarto é efetivamente um contrato formulado entre duas partes: o hotel e o hóspede. Quem aceita uma reserva, deve estar consciente que tem condições de cumprir alguns itens como: vaga na data, tipo de apartamento desejado, horário de disponibilidade, localização e mobiliário de acordo com o preço (cama de casal ou solteiro, quarto duplo, triplo, etc.). Uma reserva bem aceita facilita o serviço da recepção e torna possível a satisfação do hóspede.

- Alimentos e bebidas - atende aos hóspedes e visitantes. Na maioria dos hotéis, os restaurantes e bares são abertos à comunidade. Além dos bares e restaurantes é o departamento que atende as solicitações dos serviços de quarto - room service -, e aos eventos que acontecem no hotel. Este departamento necessita ser estruturado de acordo com as propostas mercadológicas do hotel. Um esquema básico para o departamento de alimentos e bebidas precisa ter no mínimo os seguintes profissionais: restaurante - maître, garçons, cumins e aprendizes; bar - garçons e barman; cozinheiros, confeiteiros, padeiro, copeiros, pessoal de limpeza, ajudantes de cozinha. A tendência dos setores de alimentos e bebidas fica clara na análise de Horwath and Horwath, Hotels of the Future, ao afirmarem que "há uma tendência perceptível com relação à alimentação de lazer na maioria dos países desenvolvidos. Isso significa que os restaurantes de hotéis se tornarão mais especializados, oferecendo temas especiais, e muitos poderão buscar nichos específicos de mercado". Prevêem, ainda, que os restaurantes de hotéis serão, em sua maioria, franqueados e que os avanços tecnológicos possibilitarão que mesmo os restaurantes mais simples terão a 
possibilidade de oferecer pratos de alta qualidade. Outro fator importante será a otimização da higiene e saneamento, nas dependências do departamento de alimentos e bebidas.

- Telefonia - departamento responsável por todo o fluxo de comunicação telefônica, envio e recebimento de fax e telegrama. Segundo estudiosos, este departamento tende a desaparecer devido aos sistemas inteligentes de comunicação telefônica.

- Eventos - setor que coordena os espaços destinados à realização de eventos, salas, auditórios, teatros etc. Trabalha em conjunto com os setores de alimentos e bebidas e o de reservas. Os eventos em hotéis contribuem para atenuar a sazonalidade. Não apenas os hotéis de grande porte abrigam eventos, os de pequeno porte geralmente atendem às empresas locais para reuniões, seminários e treinamentos. Dados da ABIH, afirmam que 49,4\% dos espaços utilizados para eventos no Brasil estão na hotelaria.

- Entretenimento - este setor deve cuidar das condições de higiene, segurança e orientação para a utilização dos espaços destinados ao lazer como: salão de jogos, tênis de mesa, piscina, lagos e cachoeiras, áreas verdes para caminhadas, bicicletas, cavalos, charretes, academia de ginástica, boate, cinema, sauna, equipamentos náuticos em geral. Existem hotéis que são totalmente voltados para o lazer e o entretenimento. Pessoas especializadas em lazer e recreação são os responsáveis por este departamento.

- Lavanderia - este setor está diretamente ligado à governança. O objetivo principal é a higienização das roupas de cama e banho dos hóspedes. A lavanderia pode estar situada dentro da própria estrutura física do hotel ou ser terceirizada. Atende também a pedidos de hóspedes no que diz respeito a lavar e passar roupas pessoais.

- Serviços diversos - além dos serviços citados existem outros com os mesmos valores de importância, tais como: segurança dos hóspedes e funcionários do hotel. Trabalham de acordo com orientações dos bombeiros e polícia; serviços uniformizados composto por porteiros, manobristas, mensageiros; manutenção - equipe que cuida da estrutura física do hotel, problemas com eletricidade, encanamentos, marcenarias, carpintarias etc.

- Não se esgotam aqui os serviços existentes em um hotel. Porém, entende-se que para a presente pesquisa os serviços citados são suficientes para a elaboração de um diagnóstico. Um dos serviços oferecidos pelos hotéis, principalmente os resorts, é o lazer e a recreação. Nem todos os estudiosos da hotelaria consideram lazer como parte 
do sistema de gestão hoteleira, sugerindo ate que exista uma gerência especifica para a área. As atividades de lazer nos hotéis podem ser divididas em atividades físicoesportivas (caminhada, jogos etc.), atividades sociais (festas temáticas). No Nordeste as festas juninas são muito difundidas e comemoradas; atividades manuais, atividades artísticas, atividades intelectuais e outras. Para que isto aconteça, os hotéis devem contar com profissionais especializados para coordenar as atividades.

Diante do exposto, nota-se a complexidade da organização e a importância da gestão de hotéis, que deve estar atenta às mudanças de comportamento do homem, tendo sempre em mente que:

- Portadores de deficiência estão cada dia mais participando ativamente de todos os setores da sociedade, tanto como prestadores de serviços como usuários destes serviços;

- Os mercados estão cada vez mais se abrindo, exigindo que o homem seja criativo ao desenvolver suas habilidades;

- Na hotelaria, com o aumento da expectativa de vida, a melhor idade cada vez mais participa de viagens, portanto, utiliza-se de meios de hospedagem;

- As características e potencialidades dos membros da equipe devem ser descobertas e aproveitadas;

- A hotelaria deve se preparar para atender as necessidades e preferências dos novos grupos de pessoas que surgem e se identificam cada vez mais;

- Os consumidores estão cada vez mais bem informados e exigentes, conseqüentemente, os hotéis devem ficar atentos aos aspectos que envolvem a satisfação dos hóspedes.

Assim, pode-se afirmar que os consumidores terão uma recordação diferenciada do meio de hospedagem que lhes proporcionou uma atividade ou mesmo um tratamento especial. Dentre estes tratamentos, encontra-se a hospitalidade - que a cada dia se caracteriza como ponto fundamental para o desenvolvimento do empreendimento hoteleiro.

Estudiosos e profissionais de turismo salientam a complexidade que envolve a hospitalidade. No entanto, nota-se disposição na literatura consultada em entender como funciona e quais os benefícios que a mesma traz. Presente desde sempre no contexto das atividades humanas, a hospitalidade, com o passar dos anos, foi se moldando às transformações ocorridas nos ambientes políticos, econômicos e sociais.

Compreende-se claramente a evolução da hospitalidade através dos tempos quando, recorrendo-se a uma palestra intitulada "Relações Públicas e Hospitalidade", apresentada pelo 
professor Waldir Ferreira, em outubro de 2007, na cidade do Recife durante o XVIII Congresso Brasileiro de Relações Públicas, afirma que, após estudar vários autores das áreas de filosofia, turismo, hotelaria e sociologia, elaborou uma síntese histórica sobre o assunto:

Em $170 \mathrm{aC}$, os Essênios viviam às margens do mar Morto e pertenciam a uma das cinco seitas judaicas da época. Foram fundadores de abrigos conhecidos como "beth-saida" que anteciparam em séculos os hospitais que tem seu nome derivado de hospitaleiro. Ordem dos Essênios exigiam que em todas as vilas e cidades houvesse um membro da ordem denominado "hospitaleiro" que cuidava de receber os itinerantes, provendo-os do que fosse necessário (FERREIRA, 2007).

Conceder hospitalidade é um dever, reconhecido tanto no antigo como no Novo Testamento. Em Hebreus, 13:2 diz "Não vos esqueçais da hospitalidade, porque por ela alguns, não sabendo, hospedaram anjos".

No século IV, os monges tinham a obrigação de praticar a hospitalidade e eram, sobretudo, os responsáveis pelas hospedarias, asilos e hospitais e, no século VI, São Bento formulou 73 regras que nortearam o catolicismo monástico onde duas regras tratam especificamente da hospitalidade: a regra 53 estabelece como deve ser a "recepção dos hóspedes" e a regra 66 da "importância dos porteiros nos mosteiros".

Em tempos atuais, estudiosos de várias ciências buscam conceituar e definir hospitalidade, criando grandes controvérsias, que acabam demonstrando diversos estágios, abrangendo aspectos sociais, políticos, filosóficos, culturais e econômicos. $\mathrm{Na}$ contemporaneidade, a hospitalidade gera grandes impasses mundiais, como os problemas da migração por causa de guerras e crises econômicas. Diante destes problemas, perguntas surgem cada vez mais. Por exemplo: qual a função da hospitalidade na globalização?

Boff, afirma que quatro são as virtudes de uma hospitalidade bem sucedida em tempos atuais:

Agora, nunca como antes, faz-se urgente a hospitalidade, a mútua acolhida, a
abertura generosa que supõem o despojamento dos conceitos e pré-
conceitos. Só assim captamos a diferença como diferença e não como
desigualdade e inferioridade ou como mero prolongamento daquilo que é
nosso. Em seguida, faz-se necessária a vontade de com-viver juntos na
mesma Casa Comum. Nem temos outra alternativa. Precisamos também da
tolerância sem a qual se prolonga a lógica do amigo-inimigo, da guerra e da
exclusão. Por fim a comensalidade, o sentido final da globalização, quando
todos se sentarão à mesa, finalmente juntos, para comermos e celebrarmos o
encontro e a generosidade dos bens da natureza (BOFF, 2005, p. 19).

A hospitalidade é uma forma de convivência onde as regras, os ritos e as leis são estabelecidos por determinada sociedade. Na hospitalidade instala-se a relação interpessoal, o 
que implica o surgimento de um elo social regido por valores de sociabilidade e solidariedade.

Derrida (1997), em uma palestra sobre Política e amizade, discorre sobre os receios de se desenvolver a hospitalidade incondicional nos dias atuais, uma vez que a sociedade moderna está cada vez mais urbana e individualista:

\footnotetext{
Eu tenho que - esta é uma ordem incondicional - eu tenho que, incondicionalmente, dar boas vindas ao outro, seja ele ou ela quem for, sem pedir um documento de abertura, um nome, um contexto ou um passaporte. Este é primeiro momento de abertura de minha relação com o outro; abrir meu espaço, meu lar - minha casa, meu idioma, minha cultura, minha nação, meu estado, e eu mesmo.

Eu não tenho que abri-la, porque está aberta; ela foi aberta antes que eu tomasse qualquer decisão a respeito disso: então, eu tenho que mantê-la aberta ou tentar mantê-la incondicionalmente aberta. Mas, naturalmente, este "incondicionalmente" é algo que amedronta, ele é aterrorizante
}

As características da hospitalidade são tratadas por Lashley e Morrison (2004, p. 202), após um estudo acerca dos enfoques semântico e comprobatório, para definir hospitalidade. Os autores concluem que as características mais marcantes para o tema são:

- Interessa-se pela produção e pela oferta de determinados produtos materiais, isto é, acomodação e/ou alimento e/ou bebida;

- Envolve uma relação de troca, que pode ser, sobretudo, econômica, social ou psicológica por natureza;

- Compõe-se de uma combinação de elementos tangíveis e intangíveis, cuja exata proporção varia conforme as condições específicas das diferentes situações de troca de hospitalidade;

- Associa-se a formas particulares de comportamento e interação humana;

- Não é inevitavelmente sinônimo de comportamento hospitaleiro, que é necessário, mas não suficiente para a existência da hospitalidade;

- É uma atividade assumida voluntariamente pelas partes envolvidas;

- Pode ser provida e consumida por uma variedade de motivos diferentes;

- Pode variar em sua forma específica, na função e na razão motivacional ao longo do tempo e espaço, mas, na essência, permanece qualitativamente a mesma;

- É uma atividade idealizada para gerar comensalidade e realce mútuo para as partes envolvidas;

- Envolve pessoas no processo de troca de hospitalidade;

- É uma troca que ocorre dentro de uma extensão de tempo intermediária, e que reflete a íntima conexão temporal entre suas facetas de produção e de consumo. 
Uma definição abrangente de hospitalidade é dada por Gotman apud Grinover, ao afirmar que hospitalidade é uma situação que:

permite a indivíduos ou a famílias, vindo e vivendo em lugares diferentes, construir sociedade, instalar-se e retribuir serviços e ajudas que facilitam, enquanto práticas de sociabilidade, o acesso a recursos locais, o compromisso de relações que ultrapassam a interação imediata e assegura a reciprocidade (GOTMAN apud GRINOVER 2007, p. 27).

Grinover (2007, p. 27) considera a hospitalidade uma virtude e uma qualidade social e amplia sua definição afirmando que "a análise do exercício da hospitalidade é uma contribuição para a sociologia da vida cotidiana, na qual o ser humano pode se realizar".

Diante disso o autor conclui que "a hospitalidade, enquanto desconstrói as categorias do familiar, do social e do político, permite, ao mesmo tempo, pensá-las juntas”.

Para esta pesquisa interessa a hospitalidade comercial, praticada por estruturas receptivas de turistas. Porém, acha-se necessário percorrer a evolução e os demais tipos de hospitalidade. Assim, a característica de cada tipo contribuirá para o entendimento da hospitalidade comercial, objeto deste trabalho.

Entende-se que hospitalidade, num primeiro momento, refere-se ao ato de acolher, de prestar serviço a alguém. Porém, uma análise mais profunda revela que a hospitalidade é um processo complexo onde estão embutidas as relações sociais, o que implica perceber recortes específicos de antropologia, história, sociologia, economia, geografia, comunicação, arquitetura, urbanismo, planejamento ambiental etc. Percebe-se, ainda, que por meio da hospitalidade é possível desvendar a evolução histórica de determinadas culturas. O relacionamento resultante da hospitalidade faz com que as cidades, as organizações e os seres humanos interajam e adquiram hábitos e costumes uns dos outros.

Confirma-se em Grinover, o exposto:

A troca de determinados valores entre visitado e visitante proporciona uma enorme riqueza de conhecimentos, modificando sua visão de mundo e acrescentando valores inconfundíveis ao relacionamento humano. A dimensão dessas mudanças e transformações permite novas configurações sociais e culturais. A influência provocada pelas interações, que ocorrem em localidades de grande vocação turística, refere-se ao modo de vida dos moradores, à expressão lingüística, à gastronomia, aos hábitos de entretenimento. Dessa forma, a viagem, como experiência para o turista, o viajante, pode resultar num momento preciso da construção social da pessoa, da afirmação da individualidade e da socialização (GRINOVER, 2002, p. 28). 
Como função básica, a hospitalidade tem o estabelecimento de relacionamentos ou mesmo a manutenção de um relacionamento já existente. Lashley e Morrison, ressaltam que a troca de produtos e serviços, materiais ou simbólicos é o processo entre os que dão hospitalidade, os anfitriões e os que a recebem, os hóspedes. Afirmam que:

uma vez que os relacionamentos necessariamente se desenvolvem dentro de estruturas morais, uma das principais funções de qualquer ato de hospitalidade é (no caso de um relacionamento já existente) consolidar o reconhecimento de que os anfitriões e os hóspedes já partilham do mesmo universo moral ou (no caso de um novo relacionamento) permitir a construção de um universo moral em que tanto o anfitrião quanto o hóspede concordam em fazer parte (LASHLEY e MORRISON, 2004, p. 26)

Assim, conclui-se que como funções da hospitalidade estão a transformação de desconhecidos em conhecidos, conhecidos em pessoas mais conhecidas, grupos diferentes em grupos mais próximos, minorias em grupos aceitáveis.

Entende-se que a natureza e a importância da hospitalidade são variáveis no tempo e nos lugares. Elas dependem das características, da cultura, dos costumes e hábitos de cada sociedade. Portanto, o bom hospedeiro será aquele que deixa seu hóspede feliz e satisfeito em suas necessidades básicas de sobrevivência e moralidade. Já o hóspede, na literatura pesquisada, está dividido em três tipos distintos: o que precisa de hospedagem, o amigo e o que mantém um relacionamento oficial, como, por exemplo, o de estudantes com o diretor em um albergue.

Quanto à sua natureza a hospitalidade pode, segundo Cruz (2002, p. 41), ser sociocultural, política, profissional e espacial. Resume-se, a seguir, as características de cada uma com base nos estudos da autora:

- Sociocultural - Como fenômeno sociocultural, a hospitalidade pode ser entendida do ponto de vista de uma análise centrada no indivíduo ou em uma dada coletividade (grupo de pessoas, sociedade). Um indivíduo ou grupo de pessoas pode ter maior ou menor disposição para receber alguém. Em essência, o ato de acolher um visitante é um ato social, culturalmente construído. Também a hospitalidade pode ser voluntária ou involuntária, ou seja, nem sempre o anfitrião está recebendo o visitante de forma espontânea. Quando se trata de turismo, esse é um aspecto que não pode ser negligenciado.

- Profissional - Essa hospitalidade profissional refere-se, fundamentalmente, aos serviços para atender aos hóspedes ou aos visitantes de um dado lugar, de um modo 
geral. Nesse caso, hotéis e restaurantes são os principais elementos, mas não são os únicos.

- Político - Alguns dos produtos gerados em função de um possível interesse pela criação de um ambiente hospitaleiro, em uma dada escala geográfica (local, regional, nacional), são políticas públicas, que objetivam organizar o setor bem como maximizar seus benefícios.

- Espacial - Sistematicamente, do ponto de vista de uma análise espacial, a hospitalidade pode ser abordada nos espaços urbano ou rural.

Ainda sob o aspecto espacial, a hospitalidade tem dimensões diferenciadas em função do vínculo territorial do(s) indivíduo(s) com o espaço: residentes e visitantes ocupam posições diferenciadas.

Ainda segundo a autora citada anteriormente, estas naturezas se entrecruzam todo o tempo e seu objetivo é entender melhor o conceito de hospitalidade.

Em Grinover, reafirma-se os significados atuais de hospitalidade:

Basicamente, o entendimento na cultura anglo-saxônica de hospitalidade refere-se aos aspectos da hospedagem, da alimentação, do entretenimento e dos eventos. A outra posição, mais antiga, histórica, clássica, ultrapassa o contexto claramente comercial para enfrentar o campo complexo da Sociologia e da Antropologia. Consiste ela em satisfazer as necessidades de base (fisiológicas) e as necessidades de segurança, de reconforto, de afeto, de pessoas que estejam se deslocando, por razões religiosas ou de saúde, por meio de uma relação gratuita.

A hospitalidade atua e aplica-se na dimensão doméstica, comercial e pública, considerando o território urbano e rural como sendo o lócus, onde a hospitalidade, em se produzindo, está fundamentando suas manifestações mais complexas, como é o fato de ter-se dado à "monetarização completa", que fez prevalecer a relação de trocas de tipo puramente comercial (GRINOVER, 2007, p.21).

Entende-se, desta forma, que a hospitalidade, em seu campo de competência, atua em três dimensões distintas: a doméstica a pública e a comercial.

Hospitalidade doméstica: É a mais típica e a primeira a se ter notícias. Na hospitalidade doméstica estão incluídos os mais simples gestos do cotidiano em atenção às pessoas que estão sendo recebidas. Estes gestos se dão no âmbito presencial e virtual. Os gestos de hospitalidade devem ser considerados a partir da cultura, costumes e hábitos locais, isto é, cada localidade, cada espaço possui características próprias. Vários são os temas que englobam a hospitalidade doméstica, porém, estes mesmos temas aparecem na hospitalidade comercial e pública, demonstrando assim a inter-relação existente entre elas. A seguir, faz-se 
uma breve análise dos temas da hospitalidade doméstica, discutidos por Luiz Octávio de Lima.

- A - O cerimonial e a etiqueta (inclusive a net - etiqueta) - aqui discute-se a valorização da etiqueta moderna, quais são os hábitos e costumes atuais, a evolução da etiqueta, e a atenção dos gestos e rituais que envolvem o contato humano.

- B - O estatuto do anfitrião e do hóspede - neste item deve-se tratar do dom e da dádiva de receber e ser recebido.

- C - Os mitos da hospitalidade - o ato humano de receber e o tratamento do imaginário deste ato são aqui estudados.

- D - A privacidade (a anti-hospitalidade) - a necessidade e a exigência de privacidade cada vez mais acentuada nas grandes cidades fazem com que se crie uma forma de anti-hospitalidade e ainda, fez surgir a net - hospitalidade e a net - etiqueta, onde os contatos são virtuais por meio de telefones, fax e internet.

A hospedagem e a alimentação são atributos da hospitalidade doméstica, levando-se em consideração os hábitos e costumes locais e os hábitos e costumes do hóspede. As festas de aniversário, casamentos e batizados são momentos do entreter doméstico, e os locais onde se realizam são extensões de suas casas.

Hospitalidade pública: $\mathrm{Na}$ esfera pública, a hospitalidade pode ser analisada verificando-se se uma cidade é hospitaleira ou não. As cidades são consideradas hospitaleiras a partir de determinadas características de âmbito cultural, social, econômico, ambiental, histórico e outros. Estas características são complementadas pelas medidas urbanas que são a distância geográfica e distância temporal. Grinover (2007, p. 123), propõe a coexistência de "três dimensões fundamentais para esta análise: a acessibilidade, a legibilidade e a identidade, que estão ligadas pela escala, pelas medidas geográficas e temporais que proporcionam a compreensão da cidade".

Quanto à acessibilidade trata-se do acesso dos indivíduos ou grupos sociais, às atividades e serviços, numa proporção de igualdade para todos. São os meios de transportes, a infra-estrutura viária, os acessos aos portadores de deficiências, programas de saúde, educação e lazer, infra-estrutura de redes de esgotos, água, segurança.

Para esta análise, estudiosos no assunto criaram certos indicadores destacados por Grinover, (2007, p. 136): acessibilidade para quem? (qual categoria de usuário?); vindo de onde? (de sua residência, do trabalho?); indo para onde? (para aqueles serviços ou para um lugar de trabalho?); em que momento? (na hora de necessidade, nas horas de pico?); com que 
tipo de transporte? (automóvel, transporte coletivo, a pé); com quais informações sobre a forma e a estrutura da cidade? (informações completas ou parciais sobre a rede de transporte público, sobre a localização dos serviços ou atividades procuradas). "Dessa maneira, o acesso à cidade para todos os habitantes é o conceito básico que orienta qualquer possibilidade de uma política urbana correta". Esta acessibilidade tangível se completa com a acessibilidade intangível que refere-se à cultura, à informação, aos costumes. Pergunta-se até que ponto os moradores e os visitantes têm conhecimento destas informações? Como elas são repassadas? Atendidas estas questões tem-se atendida parte das questões de cidadania.

Em se tratando de legibilidade de uma cidade ou espaço urbano, pretende-se verificar quais as facilidades de reconhecimento que se tem de partes da cidade. Entende-se por legibilidade, segundo Grinover, como "a qualidade visual de uma cidade, de um território, examinada por meio de estudos da imagem mental que dela fazem, antes de qualquer outro, os seus habitantes". Legibilidade é a leitura dos códigos arquitetônicos e culturais de uma cidade (para se entender se ela é moderna ou histórica).

Por identidade, entende-se a construção de atributos culturais formados ao longo do tempo. Assim, a identidade de uma cidade sofre as conseqüências das mudanças que ocorrem a cada dia. Em tempos de globalização, a valorização do local produz novas identidades. Concretiza-se em Ianni (2000, p. 123), a importância da identidade que uma cidade ou espaço urbano deve ter e como em tempos modernos isto está cada vez mais complexo, refletindo as questões sociais.

A grande cidade tem sido e continua a ser, cada vez mais, uma síntese excepcional da sociedade. Muito do que é a sociedade, seja esta nacional ou mundial, se desenvolve e decanta-se na grande cidade. Aí se desenvolvem as relações, os processos e estruturas que constituem as formas de sociabilidade. Muito do que se faz e imagina nos mais diferentes círculos sociais, em âmbito micro e macro, aí ressoam. São muitas as diversidades e desigualdades, tanto quanto os impasses e os horizontes da sociedade que se expressam na cidade. Tanto é assim que a grande cidade tem sido o lugar por excelência da modernidade e pós-modernidade (IANNI, 2000, p. 123)

Pode-se entender que para ser hospitaleira a cidade precisa possuir certos atributos, como: informações espontâneas, por meio de vários elementos; ordenação na paisagem urbana; identidade perceptível; infra-estrutura básica para atender às necessidades dos moradores e visitantes; áreas de lazer e outros atributos que facilitem a vida dos moradores e visitantes. 
Entende-se, então, como cidade hospitaleira aquela que transforma seu território em espaços de convívio onde as relações sociais acontecem de maneira natural e os cidadãos usufruam adequadamente dos seus serviços.

Hospitalidade comercial: A indústria da hospitalidade inclui serviços de alimentação e bebidas, hospedagem, serviços de recreação e um vínculo com o turismo e as viagens, gerando interdependência entre eles. Sem atrações e estabelecimentos de hospitalidade não há turismo. Na realidade, o turismo pressupõe a existência da hospitalidade comercial, que é encontrada na qualidade dos ambientes pelos quais os turistas passam: estradas, agências de viagens, hotéis, restaurantes, hospitalidade pública, urbana. Esta hospitalidade turística não diz respeito apenas ao acolher bem, ela leva em consideração o bem receber, o bem atender, o bem alimentar, que acaba por seduzir o turista e suscita no mesmo o desejo de voltar e de indicar a alguém o local visitado. Nesta hospitalidade fica claro que existe o pagamento para que seja fornecido ao turista um bom alojamento, proteção, espaço, segurança.

A partir do momento que o turismo envolve os setores públicos e privados e interfere no local, a hospitalidade turística passa a ter um dimensionamento sóciopolítico gerando conflitos sociais. Na hospitalidade comercial o receber não se faz necessariamente por prazer e, sim, por "obrigação" de uma atividade. Aqui o receber está sempre embasado nos manuais que regem a hotelaria e o turismo.

No que diz respeito à hospedagem, esta será diferenciada de acordo com a remuneração dos serviços. Assim, se pode hospedar em pousadas, hotéis, resorts, cruzeiros marítimos etc. O alimentar também se dá de acordo com a remuneração que se está disposto a pagar. "A idéia de compartilhar o alimento se associa ao princípio básico da hospitalidade: o prazer de satisfazer as necessidades dos outros que, explicado por teorias psicológicas, gera uma recompensa acima de tudo emocional e que faz parte da condição humana" (Paula, 2004). Desta forma, a qualidade da alimentação e dos ambientes preparados para servi-la, bem como dos que estão servindo, influenciará o alimentar profissional. O entreter profissional passa por todos os tipos de serviços, como parques, boates e entretenimento noturno de todas as espécies. A disposição em gastar mais ou menos também definirá a qualidade dos locais e do tipo de entretenimento.

Buscou-se entender a hospitalidade comercial em Abreu (2003, p. 45), discorrendo que:

a hospitalidade comercial é uma mimetização da hospitalidade. Quando se observa o processo de recebimento e tratamento em hospitais, hotéis, restaurantes, aeroportos, aviões etc., percebe-se que na missão empresarial se 
vai buscar mimetizar a antiga missão social da hospitalidade, regulamentando e normatizando a hospitalidade comercial da organização. (2003, p. 45).

Assim, percebe-se que na indústria da hospitalidade existem medidas de graduação e classificação. Entende-se que as raízes da hospitalidade doméstica são levadas para a área empresarial, fazendo com que as organizações procurem cada vez mais atender às necessidades do homem atual, não apenas na infra-estrutura como também no tratamento dispensado a ele. Confirma-se o exposto em Montandon:

Igualmente, a hospitalidade à qual recorremos nas diferentes formas do turismo e do comércio hoteleiro é entendida de preferência como sinônimo de "boa acolhida", sem envolver as turbulências que a visão mais profunda da hospitalidade implica. Qualificar acolhida comercial como hospitalidade não é escandaloso, desde que estejamos de acordo com as definições. A utilização comercial do termo indica, em todo o caso, como a hospitalidade permanece uma marca, uma perspectiva e um horizonte para uma interação bem-sucedida entre os homens, quer sejam clientes, amigos ou simples estrangeiros com a mão estendida (MONTANDON, 2003, p. 142).

Apresentam-se, assim, reflexões que deixam claro como é complexa a temática da hospitalidade, evidenciando as questões éticas e morais que se apresentam para sociedade atual. A sociedade globalizada que pratica comunicação on-line e se integra cada vez mais no espaço virtual, coloca como desafio o exercício da hospitalidade para a manutenção das relações sociais, considerando as questões referentes à solidariedade, cidadania, qualidade de vida, responsabilidade social, respeito ao meio ambiente, entre outras, que dizem respeito ao futuro da humanidade.

Pensar a hospitalidade hoje significa pensar formas para incluir sociedades excluídas, conviver com as diferenças dentro de parâmetros de respeito, tolerância e reciprocidade, buscar o equilíbrio social e pessoal, reaprender o convívio familiar e comunitário e, fundamentalmente, excluir os sentimentos de solidão e vazio com que se defronta o homem da sociedade pós-moderna. Exercitar a hospitalidade é conviver harmoniosamente com a sociedade e a natureza, de maneira ética e moral. As organizações hoteleiras são ambientes "especiais" para a prática da hospitalidade. 
Mesmo de forma comercial, a hospitalidade, por meio do turismo pode ser entendida conforme o quadro abaixo, elaborado por Wada (2003, p. 67):

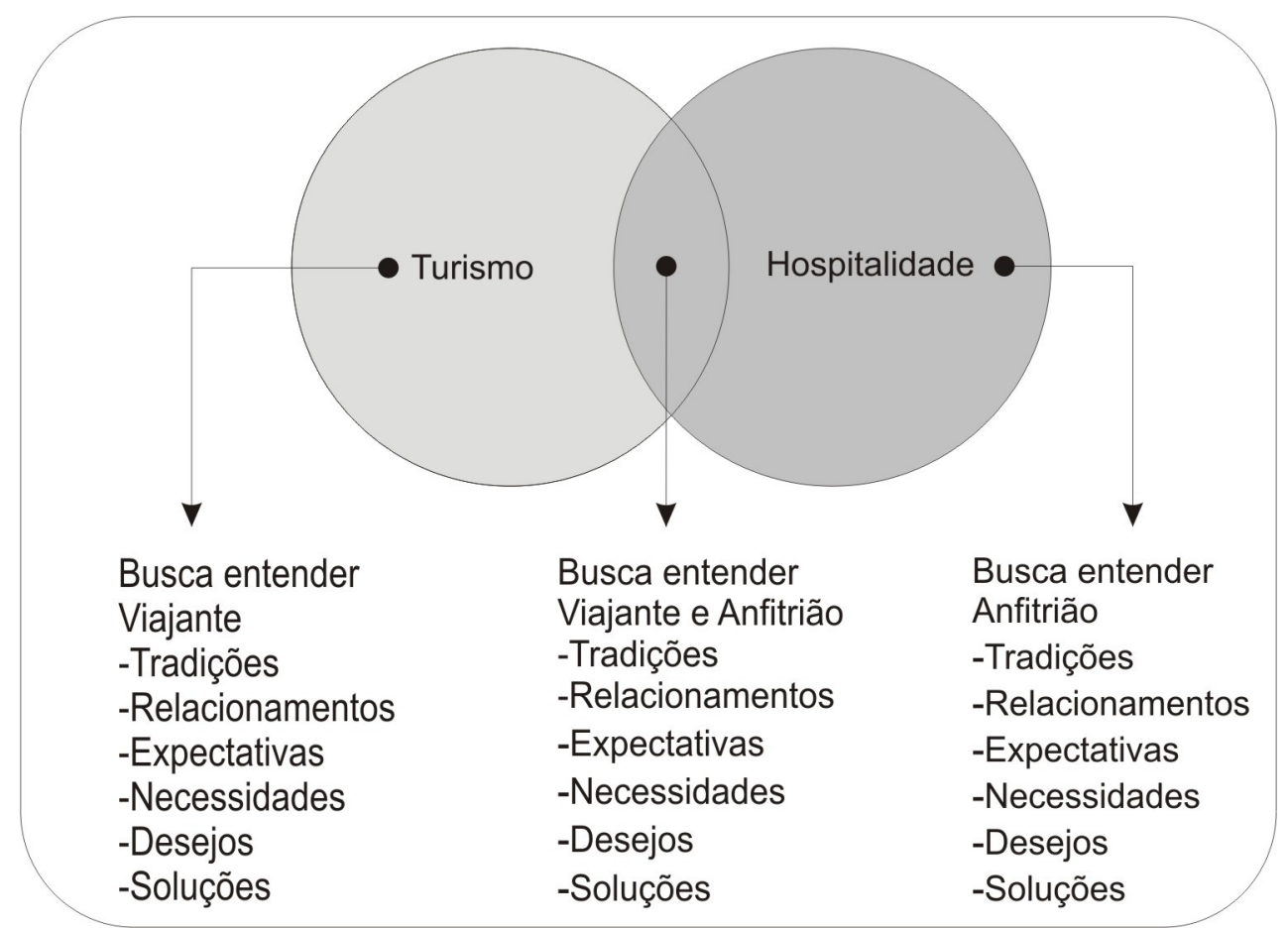

Figura 1 - Interseção entre turismo e hospitalidade e estabelecimento de itens para análise. 


\section{CAPÍTULO VI - RELAÇÕES PÚBLICAS NA HOTELARIA: UMA PROPOSTA.}

Neste capítulo busca-se compreender como as relações públicas podem ser desenvolvidas no empreendimento hoteleiro, a partir do entendimento que as relações públicas são o gerenciamento estratégico da comunicação para manter os relacionamentos existentes em uma organização. Faz-se uso do protocolo proposto para a realização da pesquisa, com o objetivo de elaborar o desenvolvimento das atividades de relações públicas nos hotéis.

Entende-se que hoje as organizações precisam ser vistas como organismos vivos, dependentes dos relacionamentos. O profissional de relações públicas necessita idealizar uma rede de relacionamentos que permita à organização ultrapassar suas fronteiras e criar uma cadeia de valor que gere estratégias de negócios. Assim, este profissional deve estar apto a estabelecer, manter e gerenciar relacionamentos, por meio das estratégias de comunicação. A habilidade de gerenciamento dos relacionamentos por meio da comunicação é essencial para que ocorra a integração, a reciprocidade e a interdependência das partes que envolvem a organização e dos seus públicos de interesse.

Confirma-se que as organizações entendem a importância dos relacionamentos com os seus grupos de interesse ao se detectar os programas de relacionamentos permanentes com seus clientes, os programas de fidelização, a criação das centrais de relacionamento com fornecedores, empregados, comunidade, o ombudsman e os ouvidores, cada dia mais presentes nas organizações.

França (2006, p. 7), confirma o exposto ao afirmar que “o foco, o 'ser' das relações públicas, é o relacionamento, ato ou efeito de relacionar-(se); capacidade de, em maior ou menor grau, conviver bem com seus semelhantes". Cada vez mais é preciso que os cursos de relações públicas percebam que as relações públicas contemporâneas estão focadas nos relacionamentos com as pessoas. O autor chama a atenção para os pesquisadores e para o Parlamento Nacional, movimento realizado pelo Conselho Federal de Relações Públicas, CONFERP, que buscam uma identidade para as relações públicas atuais:

O Parlamento Nacional arejou a concepção de relações públicas e chamou a atenção para a necessidade de adaptar seu exercício ao mundo atual. Com uma análise além das tradicionais definições descritivas, estabeleceu dois novos pressupostos para chegar a essa visão mais atualizada da profissão, que passa a ter na relação o ponto de convergência: (a) o foco nos relacionamentos e (b) a determinação de que tais relacionamentos se fazem com os públicos de interesse da organização (FRANÇA, 2006, p. 7). 
França continua sua discussão e relata que Mary Ann Ferguson, em conferência apresentada na Universidade de Maryland (1999), afirma que "o objeto de estudo de relações públicas não deve ser a organização, nem o público, nem o processo de comunicação. Ao contrário, o foco do estudo deve ser o relacionamento entre as organizações e seus públicos”.

No mesmo estudo, é expressa a opinião de Terrie Willians, quando se reporta, em apostila, sobre conferência de Grunig (2003), pronunciada em 1999, na Universidade de Maryland:

Julgo que a atividade de relações públicas como um todo está caminhando para ser uma atividade baseada no relacionamento e para se tornar uma atividade mais impessoal e fundamentada na tecnologia. Pensamos em arranjos, nos efeitos dos bytes [destaque do autor], em estórias enlatadas. Esquecemos de pensar em gente. Mas a base verdadeira do termo "relações públicas" são as ligações entre pessoas (Informação Verbal). ${ }^{2}$

Vários são os modelos de gerenciamento dos relacionamentos das organizações. Dentre os pesquisados para este trabalho, optou-se pelo Modelo Organizacional SPARSE, anacrônico de Strategy, Processes, Architecture, Resources, Systems na Empowermente (grifo nosso), onde todos os sistemas precisam estar em alinhamento e equilíbrio. Greenhalgh, explica o modelo e também o termo:

O termo "SPARSE" também é um checklist. Para ser um gerente eficiente, você precisará entender a estratégia (Strategy); otimizar os processos (Processes); administrar a arquitetura (Architecture), tanto no interior de sua própria organização como na rede de parceiros na cadeia de valor; garantir que os recursos (Resources) adequados estejam disponíveis; fazer funcionar e evoluir os sistemas (Systems) que facilitam a implementação da estratégia; e dar Empowerment para as pessoas que, na realidade, fazem a cadeia de valor funcionar, adaptar-se e melhorar todos os dias (GREENHALGH, 2002, p. 33).

\footnotetext{
${ }^{2}$ WILLIANS, Terrie. Apostila sobre conferência de Grunig (2003), pronunciada em 1999, na Universidade de Maryland
} 
Percebe-se diante do exposto, que todos os elementos devem estar alinhados e deverão receber a mesma atenção - só assim a organização será eficiente. Os elementos que proporcionam a harmonia organizacional, se bem alinhados, são mostrados na figura a seguir:

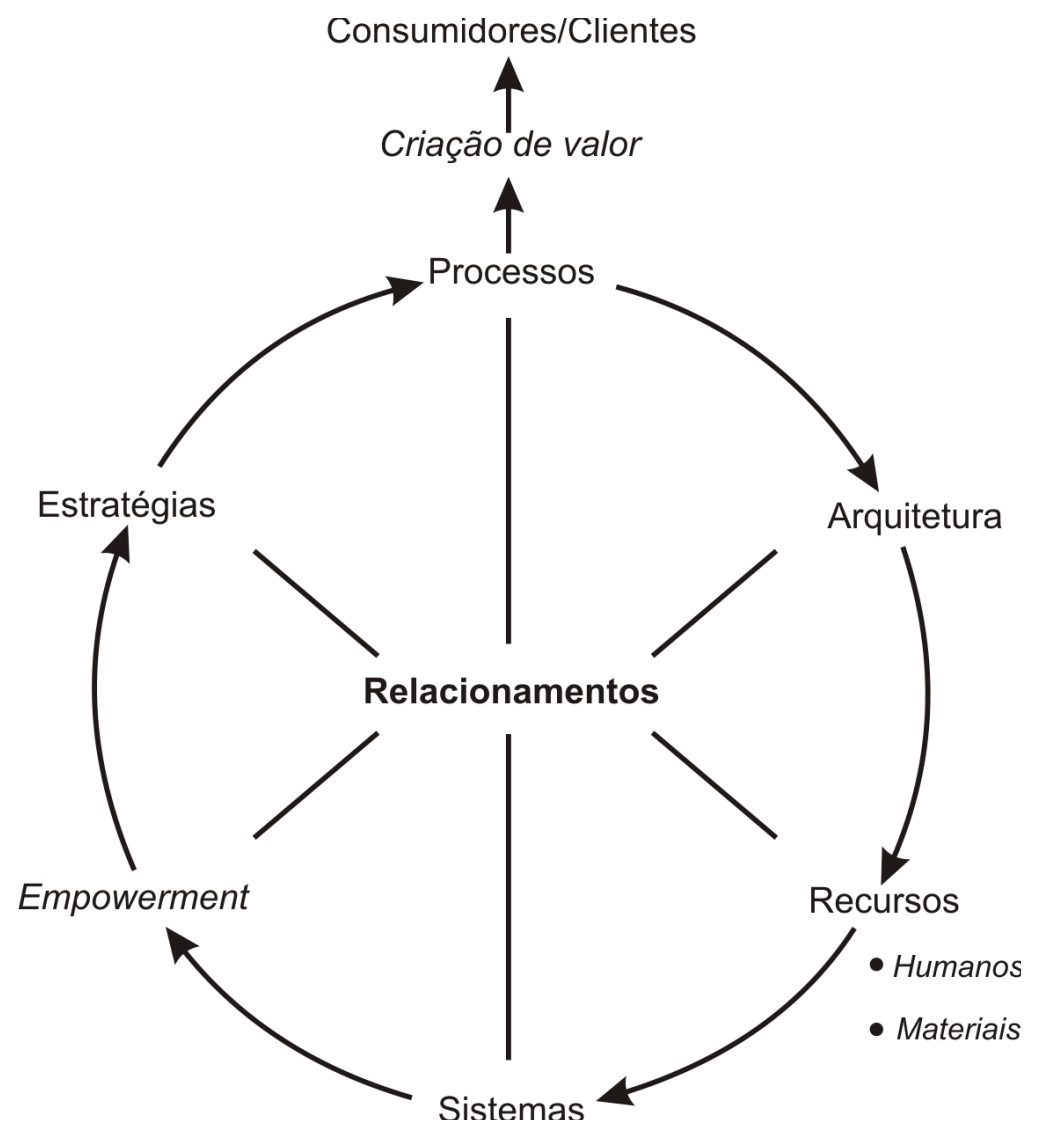

Figura 2 - Modelo Organizacional SPARSE - Integração Gerencial na Nova Era

Nota-se que a figura mostra, por meio das flechas, uma sequiência de coordenação que representa um ciclo, onde cada elemento precisa ser constantemente ajustado e monitorado, pois as organizações funcionam num ambiente de constantes mudanças.

Os relacionamentos são o centro do modelo e os mais conhecidos são: relacionamento entre indivíduos, que mantêm um relacionamento com os grupos e com a organização; relacionamentos entre grupos, que mantêm relacionamentos com a organização e os relacionamentos das organizações entre si. Estes relacionamentos precisam ser construídos e mantidos para que o modelo funcione. Algumas informações são fundamentais sobre cada elemento do modelo SPARSE, para melhor entender-se como o mesmo funciona.

Os consumidores ocupam lugar de destaque, uma vez que a sobrevivência e a prosperidade da organização dependem de como ela satisfaz as suas necessidades. Aqui, destaca-se a criação de valor por meio de um conjunto de processos. Estes processos precisam 
estar alinhados à estratégia organizacional; só assim, a organização ganha vantagem competitiva.

A arquitetura organizacional precisa ser compreendida pelos gerentes. Segundo Greenhalgh (2002, p. 35), o termo arquitetura "engloba todas as configurações organizacionais necessárias para executar os processos que criam valor. Isso pode incluir vários grupos, vários departamentos ou até várias empresas".

Quanto aos recursos, cabe ao gerente, após o estabelecimento dos processos e da arquitetura, garantir sua viabilização. Os recursos humanos e materiais devem estar disponíveis e ser suficientes para execução dos processos que criam valor os quais vão implementar a estratégia.

Os sistemas como avaliação, controle, monitoramento do ambiente, comunicação e informações, mostram ao gerente quando tudo está indo bem ou quando alguma coisa precisa ser reavaliada ou replanejada.

O empowerment é o espaço de manobra para que os gerentes tomem alguma decisão ou deleguem a um subordinado para fazê-lo.

Com base em Greenhalgh (2002, p. 46), constroem-se os tipos de relacionamentos necessários a uma organização.

- Relacionamento entre indivíduos - o relacionamento mais comum entre as pessoas em uma organização são os relacionamentos que envolvem a interação entre os papéis. A interação entre as pessoas cria relacionamentos interpessoais complexos independentes, na maioria das vezes, daquilo que o organograma e as descrições de cargo estabelecem. As dimensões do relacionamento interpessoal podem ser divididas em quatro grupos: "rapport (grau de conforto que as pessoas têm na relação), vínculo (a solidez do relacionamento quando ele enfrenta alguma dificuldade), amplitude (quando o relacionamento se estende além dos papéis que cada um desempenha na organização) e afinidade (o quanto a pessoa atrai você)". O autor entende ser rapport um termo usado na neurolingüística, que significa relação de mútua confiança e compreensão ente duas ou mais pessoas; capacidade de provocar reações da outra pessoa. 
Abaixo uma proposta do autor para o entendimento das dimensões dos relacionamentos interpessoais, destacando-se os seus pontos fortes e fracos:

\begin{tabular}{|c|c|c|}
\hline $\begin{array}{c}\text { DIMENSÃO DO } \\
\text { RELACIONAMENTO }\end{array}$ & $\begin{array}{c}\text { PÓLO QUE } \\
\text { ENFRAQUECE O } \\
\text { RELACIONAMENTO }\end{array}$ & $\begin{array}{l}\text { PÓLO QUE FORTALECE O } \\
\text { RELACIONAMENTO }\end{array}$ \\
\hline \multicolumn{3}{|l|}{ DIMENSÕES DE RAPPORT } \\
\hline Confiança & Desconfiança & Total confiança \\
\hline $\begin{array}{l}\text { Abertura interpessoal } \\
\text { Empatia }\end{array}$ & $\begin{array}{l}\text { Distância social } \\
\text { Não empatia }\end{array}$ & $\begin{array}{l}\text { Vulnerabilidade } \\
\text { Forte empatia }\end{array}$ \\
\hline Aceitação & Rejeição & Consideração positiva incondicional \\
\hline Respeito & Desrespeito & Total respeito \\
\hline \multicolumn{3}{|l|}{ DIMENSÃO DE VÍNCULO } \\
\hline Aliança & Inimigos & Aliados \\
\hline Competição & Competição & Colaboração \\
\hline Intercâmbio econômico & Nenhum benefício & Grande benefício \\
\hline \multicolumn{3}{|l|}{ DIMENSÕES DE AMPLITUDE } \\
\hline Escopo & Restrito & Ilimitado \\
\hline Horizonte de tempo & Enquanto dura a transação & Contínuo \\
\hline \multicolumn{3}{|l|}{ DIMENSÕES DE AFINIDADE } \\
\hline Estimulação & Tediosa & Interessante \\
\hline Compartilhamento de coisas em comum & Nada em comum & Muito em comum \\
\hline Simpatia & Antipatia & Grande afeição \\
\hline Envolvimento sentimental & Repulsa & Atração \\
\hline
\end{tabular}

QUADRO 4 - Dimensões dos Relacionamentos Interpessoais.

- Relacionamento entre grupos em organizações - os grupos se formam por meio das pessoas que ele exclui e das pessoas que ele inclui. Onde existir um grupo vai haver solidariedade e divisão, a solidariedade no interior do grupo e a divisão entre grupos. Para a antropologia, o endogrupo é um grupo ao qual você se identifica e o exogrupo é um grupo ao qual você não pertence. Em geral o exogrupo é visto como um adversário um competidor. Nos relacionamentos entre os grupos dentro da organização destacamse: relacionamentos entre funções corporativas; relacionamentos entre castas organizacionais; sindicatos e gerências e outros.

- Relacionamento do indivíduo com o grupo - a questão da informação faz com que os funcionários de uma organização sintam-se incluídos ou excluídos de determinados grupos. Aqui estão os relacionamentos entre chefe com os grupos. Para as organizações modernas é muito importante que as pessoas façam parte de determinados grupos, pois a diversidade interna permite que os grupos se adaptem a 
novos desafios. As organizações são redes integradas de grupos onde a habilidade para formar grupos sólidos está na integração das pessoas com os grupos ao qual ela pertence. Aqui o papel de gerenciamento é o de administrar os relacionamentos de grupo dentro e entre os grupos.

- Relacionamento entre organizações - o relacionamento entre organizações depende da natureza da competição existente entre elas. Esta competição pode ser implícita ou dirigida. A competição implícita é impessoal, os competidores podem nunca se ver ou mesmo ter algum tipo de contato, já a competição dirigida é aquela em que os competidores se defrontam abertamente por meio principalmente, da propaganda comparativa. Atualmente, nota-se que as organizações, mesmo as concorrentes, procuram criar vínculos que perdurem por muito tempo a fim de gerenciar conflitos advindos da sociedade globalizada.

- Relacionamento entre indivíduos e organizações - os relacionamentos dos indivíduos com as organizações podem ser positivos, quando melhoram a eficácia da organização, ou negativos, quando acabam por prejudicá-la. Vários são os relacionamentos do indivíduo com a organização, dentre eles destacam-se: organização-funcionário, organização-cliente e organização-representante.

Tomando como base o protocolo apresentado para a realização da pesquisa criou-se uma proposta para a implementação e execução das atividades de relações públicas na rede hoteleira do Nordeste do Brasil. Para tanto, a implantação de políticas na rede hoteleira tornase imprescindível e acontecerá no momento em que os segmentos administrativos se derem conta do valor da comunicação e a perceberem não apenas como núcleo distribuidor de informações geradas por seus setores, mas que deverá funcionar como termômetro dos anseios dos seus públicos de interesse, na sua relação com a sociedade local e regional. Políticas de comunicação bem elaboradas estrategicamente, que objetivem um encontro de idéias, de linguagem e metas comuns, resultarão na identificação, na promoção, na divulgação e no reconhecimento como empresa cidadã, do hotel que a praticar profissionalmente. É necessário que se instalem políticas capazes de gerar um intercâmbio entre os hotéis, com seus públicos de interesse e com as diversas facções da sociedade.

Estabelecem-se políticas de comunicação para a projeção de metas, possibilitando maior produtividade e, conseqüentemente, competitividade - o que contribuirá para que o hotel atenda aos seus objetivos e busque solucionar os problemas que surgirem. As políticas devem ter como objetivo a integração da comunicação, o bem da comunidade e a sobrevivência da organização. 


\section{1 - PESQUISA COMO FUNÇÃO DE RELAÇÕES PÚBLICAS.}

A pesquisa possibilita um caráter científico às atividades de relações públicas dando, ao mesmo tempo, credibilidade nas suas ações. Segundo Kunsch (2003, p. 278), os objetivos básicos da pesquisa são:

conhecer a opinião dos públicos; construir diagnósticos da área ou do setor de comunicação organizacional/institucional; conhecer em profundidade a organização, sua comunicação e seus públicos para a elaboração de planos, projetos e programas especiais de comunicação; fazer análise ambiental interna e externa, verificando quais implicações que possam afetar os relacionamentos (KUNSCH, 2003, p. 278).

Assim, um hotel, por meio de pesquisas, poderá identificar os seus públicos, perceber os seus anseios e elaborar programas específicos para cada um. Acha-se, então, importante a pesquisa em hotelaria para a definição de quais serviços deverão compor as atividades da organização. A pesquisa permitirá à organização hoteleira:

- Entender em que amplitude os seus públicos conhecem as atividades e funções da hotelaria;

- Saber, antecipadamente, qual será a reação dos seus públicos sobre uma decisão a ser tomada pela organização;

- Avaliar quais as necessidades dos públicos e quais medidas deverão ser tomadas, para satisfazê-las;

- Prever atitudes e comportamentos dos públicos;

- Avaliar o conhecimento dos públicos diante de problemas globais que possam afetar o desenvolvimento do hotel;

- Entender, previamente, as atitudes dos públicos diante de programas implementados pela organização, com a possibilidade de corrigir distorções.

A pesquisa proporciona às organizações a elaboração de programas de relacionamento, tornando-se imprescindível para a prática das relações públicas na hotelaria.

Como função, a pesquisa, segundo Fortes (2003, p.97), cumpre os seguintes objetivos:

Verificar o alcance dos objetivos da empresa perante os públicos;

Traçar o perfil dos públicos da organização;

Estabelecer uma base de dados para sustentar a decisão de programações; Detectar modificações no ambiente interno e externo das organizações; Fornecer diagnósticos administrativos à direção da organização; 
Levantar determinado conhecimento solicitado pela cúpula da companhia (FORTES, 2003, p. 97).

\section{2 - ASSESSORIA COMO FUNÇÃO DE RELAÇÕES PÚBLICAS.}

Objetivam-se com o assessoramento, a implementação de políticas de relações públicas, marketing, propaganda institucional e mudanças de atitude no tratar da opinião pública. Por meio de pareceres e recomendações devidamente fundamentadas e pormenorizadas, o assessoramento busca o sucesso da organização. O profissional de relações públicas, quando na função de assessor, procura identificar quais são as necessidades da organização, estabelece programas de relacionamento com os públicos, prevê e planeja soluções para os problemas comunicacionais, estabelece estratégias de atuação dentro e fora da organização, atua como conselheiro junto à administração, sugere mudanças políticas, analisa e interpreta as tendências e as mudanças globais e sugere atitudes à organização.

Dentro de um hotel, o assessor de relações públicas terá como função básica a identificação das necessidades da organização e dos seus públicos, planejando, prevendo e propondo soluções. Com a complexidade e a amplitude da área de hotelaria, o assessor de relações públicas precisa conhecer profundamente a ambiência interna e externa, - assim, estará autorizado a atuar junto a administração do hotel.

Indicadores gerais que, para qualquer tipo de organização, devem ser acompanhados e analisados pelo assessor de relações públicas:

- Imagem e conceito frente à comunidade;

- Políticas de mercado e preços;

- Atualização constante do setor de informática;

- Problemas relacionados ao meio ambiente e à responsabilidade social;

- Demanda na baixa temporada;

- Consolidação da marca no mercado;

- Crescimento regional;

- Questões relativas a transporte aéreo e terrestre;

- Outras.

Colocadas em ordem de prioridade, estudadas e analisadas, estas e outras variáveis específicas, irão contribuir para a prevenção de fatos que poderão afetar o hotel. 


\section{3 - PLANEJAMENTO COMO FUNÇÃO DE RELAÇÕES PÚBLICAS.}

Sabe-se que o planejamento pertence à área da administração, identificado com as funções de organizar, dirigir e controlar. Em relações públicas, o planejamento impede que as atividades sejam improvisadas, proporcionando que as estratégias estabelecidas sejam cumpridas sem as pressões de crises e emergências. Segundo Fortes (2003, p.187), os principais objetivos da função de planejamento das relações públicas são:

- Formular estratégias para os meios de comunicação com os públicos;

- Adequar as atividades de Relações Públicas à administração estratégica da empresa;

- Organizar os recursos técnicos e físicos dos programas de relacionamento;

- Definir estratégias de Relações Públicas para trabalhos solidários com os setores da companhia;

- Elaborar o orçamento de Relações Públicas;

- Estabelecer a rentabilidade das proposições apresentadas.

O planejamento de relações públicas numa organização hoteleira deverá contar com a colaboração de todos na sua elaboração e execução. Projetos preventivos e reativos são possíveis de serem implantados com objetivos claros e concisos, por meio das seguintes articulações:

- Fazer com que todos os funcionários conheçam o hotel, seus espaços, seus setores, a função e o responsável por cada um deles;

- Selecionar quem é o porta-voz da organização mantendo-o munido de dados e informações;

- Elaborar projetos para situações emergenciais e torná-los conhecidos de todos;

- Preparar indivíduos para que resolvam problemas específicos;

- Estabelecer programas de relacionamento com os segmentos de públicos;

- Elaborar programas específicos para cada temporada de turismo;

- Simular possíveis situações de risco;

- Editar manuais necessários;

- Estabelecer alianças com poderes públicos, imprensa, associações de classe e outras, grupos de interesse, sindicatos, e outros;

- Submeter à mecânica de comunicação a testes regulares, verificando sua eficácia. 
Estes e outros projetos tornarão o hotel conhecido dos seus públicos, especificamente os funcionários que entenderão o valor e a abrangência de suas atividades, percebendo o quanto seu trabalho é importante para o hotel.

\section{4 - EXECUÇÃO COMO FUNÇÃO DE RELAÇÕES PÚBLICAS.}

$\mathrm{Na}$ execução desenvolvem-se as etapas do processo de comunicação. Aqui, produz-se o material necessário para o relacionamento com os públicos; instrumentos e veículos são determinados. Possui como suporte a pesquisa e o planejamento. A pesquisa proporciona que as atividades não sejam apenas reativas; e o planejamento, a orientação adequada para cumprir as estratégias previstas. São em grande quantidade as classes de atividades, sendo que uma não se sobrepõe à outra em importância. Dentre elas destacam-se, para o hotel:

- Divulgação - elaborar e supervisionar a criação e distribuição de boletins, material impresso, campanhas institucionais, material para ser distribuído eletronicamente, artigos técnicos, manuais, periódicos, newsletters, jornais, folhetos, folderes, relatórios, balanço social, filmes etc. Estes instrumentos de comunicação devem ser específicos para cada segmento de público. Nos hotéis, a publicação de folderes, dirige-se às operadoras de turismo, feiras e eventos especiais. Cabe ao profissional de relações públicas, na hotelaria, acompanhar entrevistas, providenciar treinamento para os entrevistados, manter atualizados os conteúdos das informações nos meios eletrônicos.

- Atendimento ao público - implantar cadastros de hóspedes, imprensa e autoridades locais e/ou regionais, entidades da área de turismo e hotelaria. Planejamento, elaboração e execução de visitas ao hotel, técnicas nas localidades onde houver cursos de turismo. Apoiar e participar de programas de qualidade, reciclagem, meio ambiente. Manter correspondência tradicional e virtual com hóspedes. Inspecionar os serviços de telefonia, recepção, reservas e governança. Manter atualizados os murais para o público interno. Elaborar briefing para reuniões, analisar qualitativamente as publicações sobre a organização. Públicos especiais necessitam de reciprocidade de comunicação. Para os hotéis os relacionamentos com os públicos oficiais de turismo e hotelaria, em nível local, estadual e nacional.

- Eventos - áreas importantes da rede hoteleira do Nordeste, os eventos, devem ser planejados e acompanhados diretamente por pessoa preparada para tal função. Embora nos hotéis pesquisados os eventos constituam apenas a infra-estrutura e serviços de 
alimentação, bebidas e garçons, o hotel precisa trabalhar o evento em todos os setores. A recepção, porteiros, telefonista e o site do hotel necessitam ter todas as informações sobre o(s) eventos(s) que estão acontecendo ou que irão acontecer. Quadros indicativos devem estar em lugares de destaque para que possam ser visualizados com facilidade.

A execução é o momento que ocorre o contato com os públicos de uma organização, portanto, torna-se importante a segmentação destes públicos, o tipo de comunicação que será utilizado e qual a via de utilização. Nos hotéis, a recepção, telefonia e governança são "instrumentos" primordiais para o sucesso de um programa de relações públicas voltado para os clientes.

\section{5 - AVALIAÇÃO COMO FUNÇÃO DE RELAÇÕES PÚBLICAS.}

Várias são as formas de avaliação dos programas de relações públicas. Como detectado nesta pesquisa, os hotéis não avaliam suas atividades. A dificuldade de avaliação concentra-se na intangibilidade dos resultados de relações públicas, contrário aos resultados de marketing e propaganda. Segundo Kunsch (2003, p. 355), “embora a avaliação figure como a última etapa do processo de planejamento, ela faz parte de todo esse percurso, pois permite um equacionamento, numa perspectiva crítica, do que vai sendo planejado e, posteriormente, do que foi realizado e dos resultados obtidos". Em Pereira (2004, p. 29), encontra-se o sentido dado a número. "Numerus, em latim, não tem o sentido restrito que possui em português, mas pode significar ritmo, música, harmonia ou métrica, estratégia de medida, de descrição". Constata-se, portanto, que tudo na natureza é passível de mensuração, basta identificar qual numerus é adequado a essa tarefa. Assim, entende-se que diante dos vários métodos existentes para a avaliação, cabe a cada profissional identificar o mais adequado para o seu projeto, levando em consideração as características e circunstâncias envolvidas. 


\section{CONCLUSÃO}

Nesta pesquisa, procurou-se realizar um diagnóstico para verificar como acontecem as atividades de comunicação na rede hoteleira do Nordeste do Brasil, com o objetivo de identificar se as funções e atividades de relações públicas são ali desenvolvidas, o que constitui o problema do presente trabalho. A hipótese "o mercado turístico/hoteleiro da região Nordeste do Brasil pode ser um espaço de atuação do profissional de relações públicas, por meio da implementação e conhecimento dessas atividades por parte dos gestores de truísmo/hotelaria”, comprova-se com base nos dados coletados descritos abaixo:

Conforme o protocolo utilizado para o desenvolvimento deste trabalho, o primeiro item investiga se os hotéis realizam pesquisas junto aos seus públicos de interesse. Constatouse, assim, que a pesquisa nos hotéis é praticada das mais variadas formas. Com os hóspedes, está alicerçada nos questionários deixados na recepção ou nos quartos. Possui os mesmos formatos nos hotéis pesquisados, (o de um envelope) e as mesmas perguntas, buscando identificar se os hóspedes foram bem tratados pelos vários departamentos que utilizaram. Observou-se que o retorno é mínimo, pois a pesquisa ocorre na hora que o hóspede está deixando o hotel. Encontrou-se, ainda, hotéis que realizam pesquisas de satisfação, uma semana após a saída do hóspede. Neste caso isolado, a pesquisa é realizada por uma empresa terceirizada, localizada nos Estados Unidos (todos os dias o hotel envia os dados dos hóspedes que deixam o hotel e esta empresa entra em contato via e-mail). Os entrevistados não souberam informar sobre os resultados. No geral, os resultados das pesquisas são encaminhados ao gerente, que se dirige aos chefes dos setores para informar as reclamações ocorridas. Assim, constatou-se que a pesquisa com hóspedes não é satisfatória no complexo hoteleiro da região Nordeste do Brasil.

As pesquisas junto aos funcionários são inexistentes nos hotéis. Nas raras possibilidades de se manifestarem, os funcionários são convidados para reuniões esporádicas, onde podem expor suas opiniões. Encontraram-se, também, hotéis que afirmaram praticar pesquisas anuais, onde os funcionários não são identificados, porém, os entrevistados não souberam informar os resultados de qualquer uma delas.

Idêntica situação encontrou-se nas pesquisas realizadas junto à comunidade. $\mathrm{Na}$ realidade, identificou-se que não existe preocupação com o entorno dos empreendimentos hoteleiros; isto se modifica quando a comunidade onde o hotel está localizado influencia de forma direta no hotel. Um exemplo é o do hotel Pestana Convento do Carmo localizado no centro histórico de Salvador, Bahia, especificamente no Pelourinho. O Pelourinho vive nos 
dias atuais, segundo a imprensa local, uma forte queda em todos os seus aspectos: a região voltou a ser um local tido como perigoso, com grande número de assaltos aos turistas, concentração de uso e vendas de drogas, falta de segurança, grande número de prisões de bandidos perigosos etc. Segundo o entrevistado, esta situação refletiu na ocupação do hotel, ocasionando desistência de grupos de turistas. Outra situação que merece ser registrada é a do hotel Starfish Ilha de Santa Luzia, em Sergipe. Localizado numa comunidade pobre da cidade, o hotel optou que seu quadro de funcionários fosse composto por moradores locais. Assim, chegou-se à definição que do total de funcionários $80 \%$ fosse de moradores locais. Para tanto, segundo o entrevistado, os treinamentos são constantes, criando-se dessa maneira uma reserva de profissionais que podem, além de trabalhar no hotel específico da comunidade, atuar nos demais empreendimentos hoteleiros do Estado. Em nenhum dos dois casos citados houve a preocupação, segundo o entrevistado, em realizar uma pesquisa na comunidade. Assim, podese constatar que os hotéis da região Nordeste do Brasil não têm a preocupação em identificar os seus públicos de interesse, de forma a criar e manter um relacionamento com os mesmos. Não existe, na visão dos dirigentes destes hotéis, a necessidade de mapear, identificar e conhecer os seus "clientes".

Em uma organização complexa como um hotel, a elaboração de políticas de comunicação resultará em uma maior produtividade, na utilização correta dos instrumentos de comunicação, na informação e interação de seus vários segmentos de públicos e na interligação com os demais empreendimentos hoteleiros. Porém, no que se refere às políticas de comunicação, marketing e relações públicas, os hotéis não possuem um plano para ser seguido e executado. Os entrevistados entendem a necessidade de um plano que tenha objetivos a serem cumpridos, mas, confessam, que isto nunca ocorreu.

Esta situação fica evidente na consulta ao Manual de Conduta Hoteleira, disponível no site da $\mathrm{ABIH}$ (www.abih.com.br), criado e editado pela mesma, que tem como objetivo a orientação dos gestores de meio de hospedagem com fins de uma possível padronização de posturas. A $\mathrm{ABIH}$, na apresentação do Manual, considera que o mesmo será ferramenta complementar e auxiliar no processo de capacitação profissional dos gestores de meios de hospedagem, propiciando a criação de novas competências e habilidades profissionais e sociais. Conclui esperando que o Manual seja fonte para a melhoria da informação e da qualidade dos serviços prestados.

Dividido por assuntos como segurança, ética, roubos e furtos, meio ambiente, e outros o Manual apresenta, ao final de cada um deles, um "case" e uma seção de "perguntas \& respostas". No assunto comunicação, fica evidente qual é a filosofia da ABIH. A introdução 
fala de uma época em que as informações circulam com rapidez, da necessidade dos empreendimentos hoteleiros não apenas fazer publicidade como também da necessidade de assegurar a boa imagem do estabelecimento. Afirma que a imagem que uma empresa tem perante a opinião pública é decisiva para estabelecer a boa ou má receptividade da população em relação a suas atividades. Concluindo o item, os produtores do Manual entendem ser importantes a publicidade verdadeira e a produção de matérias jornalísticas para revistas e jornais - quase sempre, e não somente no segmento de hospedagem, a preocupação maior dos gestores está direcionada para a comunicação com o cliente. Páginas na internet, cartazes, panfletos, publicidade em revistas e jornais especializados são, hoje em dia, meios de comunicação frequentemente utilizados para sobressair em meio à acirrada concorrência. Mas é preciso obedecer alguns parâmetros na hora de anunciar. O Código de Defesa do Consumidor é bastante objetivo quando determina que a publicidade deva ser veiculada de tal forma que o consumidor, fácil e imediatamente, a identifique como tal. Outra maneira de se chegar ao público é por meio de matérias produzidas por jornalistas para revistas e cadernos especializados em turismo - que não implica nenhum custo para o proprietário do estabelecimento.

Diante desta posição 'oficial' da ABIH, identifica-se uma preocupação apenas com a divulgação dos serviços oferecidos pelos empreendimentos hoteleiros e a confirmação de que a comunicação para os hotéis objetiva a busca de clientes. Assim, entende-se que a comunicação nos hotéis da região Nordeste do Brasil, pelo exposto acima, não está articulada com a missão dos mesmos. Porém, embora desordenada e sem uma política definida, a comunicação acontece. Pode-se confirmar o exposto ao analisar os dados referentes aos instrumentos de comunicação que são utilizados nos hotéis.

Não existem publicações específicas para os empregados dos hotéis. Apenas o hotel Pestana Convento do Carmo, indicou uma publicação mensal direcionada aos empregados, chamada Pestana News. Trata-se de um boletim com notícias referentes ao hotel. Em se tratando de publicações para os hóspedes ocorre o mesmo. Vale registrar, entretanto, que o Ocean Grande Hotel Natal publica diariamente um boletim com tábuas da maré, horários para apreciar o pôr do sol, atividades de lazer do dia. Este boletim é colocado em todos os apartamentos, sob a porta, antes de o hóspede levantar-se. As publicações existentes são os folderes direcionados às agências de viagens e operadoras de turismo.

Confirma-se o exposto ao verificar-se a bibliografia consultada: em se tratando de informática, os hotéis estão equipados e investem na área. Especificamente para a 
comunicação com clientes e com empregados, os hotéis possuem sites, intranet e o "fale conosco", por meio de e-mails.

Os hotéis não possuem um programa de visitas da comunidade às suas instalações. As visitas ocorrem onde existem cursos de Turismo e Hotelaria, quando são agendadas pelas Faculdades. Portanto, constatou-se que um programa de visitas onde comunidade, os familiares dos empregados, escolas tivessem acesso às instalações do hotel não acontecem.

Quanto aos mailing, também são inexistentes nos hotéis: imprensa local e nacional, autoridades, formadores de opinião não são cadastrados nos hotéis. Os endereços atualizados são os das entidades de turismo e hotelaria em nível nacional.

Os arquivos de áudio, fotos e imagens não figuram nas atividades dos setores consultados. Não existe a preocupação com a preservação da memória dos hotéis pesquisados.

Os murais estão presentes nos hotéis, tanto para os hóspedes quanto para os funcionários. Os murais para hóspedes estão localizados na recepção e divulgam os eventos que estão ocorrendo no hotel, excursões, atividades de lazer. Para os funcionários, os murais localizam-se no refeitório e divulgam notícias do hotel e avisos (institucionais).

O item evento merece destaque nesta pesquisa, uma vez que os hotéis estão voltados para a captação de eventos e, principalmente, para sediar os mais variados tipos de eventos. Os eventos começaram a acontecer na área de turismo no século XIX, mas sua consolidação se deu no século XX. A cada dia, aumenta o número de feiras, exposições, congressos, seminários e muitos outros tipos. Os hotéis da região Nordeste do Brasil possuem um departamento específico de eventos, que pode às vezes estar ligado ao marketing. A infraestrutura é preparada para a realização dos mais variados tipos de eventos. Salas, de vários tipos e tamanhos, auditórios com capacidades variadas, locais para feiras, cadeiras, mesas e outros itens necessários para a acomodação de pessoas compõem a infra-estrutura oferecida aos organizadores de eventos. Serviços de filmagem, som, fotografias, decoração e outros são de responsabilidade dos promotores do evento. Os hotéis não permitem que outro buffet faça o serviço de alimentação dos eventos. Os departamentos de eventos dos hotéis não planejam os eventos; a função dos mesmos é disponibilizar as áreas, funcionários especializados para os serviços, como: alimentação, coffe-breack, almoços, jantares, coquetéis e destas específicas. Além dos eventos que promovidos por outras entidades e instituições, os hotéis realizam eventos festivos como: revelion, dia dos namorados, dias dos pais, dia das mães, natal, colônia de férias, etc., e, invariavelmente, uma feijoada aos sábados direcionada à comunidade.

Assim, pode-se afirmar que a pesquisa detectou, que os hotéis da região Nordeste do Brasil produzem pouca informação, sem se preocuparem em planejá-las, o que dificulta a 
concretização dos objetivos estabelecidos pela organização hoteleira. A comunicação é executada a partir de uma visão voltada para as vendas sempre objetivando atrair novos clientes. Dentre as atividades de comunicação, encontram-se embutidas atividades de relações públicas desconhecidas de quem está à frente do setor de comunicação. As atividades de relacionamentos com os públicos de interesse estão a cargo dos setores de recursos humanos, sem, no entanto, existir a preocupação pelo setor de comunicação, na produção de instrumentos que viabilizem estes contatos.

A pesquisa possibilitou ainda, observar como estão estruturados os setores de comunicação, e quais os profissionais que atuam nestes setores. Assim, constatou-se que os funcionários, que respondem pela comunicação nos hotéis da região Nordeste do Brasil, não são da área de comunicação e geralmente estão alocados nos setores de marketing ou eventos. A comunicação, quando acontece, é apenas a distribuição de folhetos publicitários ou a reprodução de atividades enviadas por escritórios localizados em São Paulo. Conclui-se, desta forma, que a comunicação é apenas a execução de tarefas. Percebeu-se também, que não existe um conhecimento sobre o papel da comunicação, mesmo por quem a pratica, que é confundida com eventos, marketing, notas para a imprensa local.

Por ter sido uma pesquisa qualitativa houve a possibilidade de identificar como os dirigentes dos hotéis percebem a comunicação e qual valor é a ela atribuído. Os mesmos entendem a comunicação como um canal para atrair novos clientes, sempre ligada ao marketing, às vendas e à publicação de notas na imprensa local. O valor atribuído à área de comunicação nos hotéis pesquisados é de um setor tarefeiro que tem como objetivo a busca de clientes e não a manutenção do relacionamento da organização com os seus públicos de interesse.

Dentre os objetivos propostos, afirma-se que as dúvidas quanto ao papel das relações públicas na rede hoteleira do Nordeste do Brasil, continuam a existir como se a função desta atividade fosse aquela já debatida, discutida e esquecida dos anos 80, onde o profissional era visto como tarefeiro e nunca como um estrategista dentro da organização.

Embora a pesquisa tenha sido qualitativa, salientou-se no trabalho que isto não enviabilizaria resultados quantitativos. Referente aos profissionais de relações públicas que atuam nos setores de comunicação, dos 27 hotéis pesquisados encontrou-se um profissional de relações públicas que afirmou não desenvolver atividades específicas da área.

Quanto aos programas de relacionamentos com os públicos, identificou-se programas frágeis sem embasamentos, sem planejamento e principalmente sem continuidade. Os que existem estão voltados para as operadoras de turismo na busca de novos clientes. Os contatos 
pós hospedagem nunca acontecem diretamente com os hóspedes e sim, quando acontecem, eles ocorrem com a empresa que o enviou seja ela uma organização turística ou não. Um exemplo bem claro disso são as companhias aéreas que hospedam diariamente seus tripulantes. Segundo os entrevistados, não existe a preocupação do hotel em se relacionar com os tripulantes (hóspedes), todo o relacionamento se dá com a companhia.

Diante deste cenário, pode-se afirmar que não existem, na realidade, atividades de relações públicas na rede hoteleira da região Nordeste do Brasil, porém existe sim mão-deobra desqualificada para este tipo de atividade e, consequentemente desperdício de tempo, de material e desperdício financeiro.

Estas informações possibilitam afirmar que:

- A administração dos hotéis da região Nordeste do Brasil, composta por profissionais das mais diversas áreas do conhecimento, não possuem a percepção do verdadeiro papel da comunicação na organização e, consequentemente não possuem conhecimento da importância de se manter um bom relacionamento com os públicos de interesse da mesma;

- Os setores de comunicação dos hotéis precisam imediatamente repensar suas funções, discutindo com o seu público interno quais as políticas de comunicação devem ser adotadas para que a organização atue de acordo com as novas exigências da sociedade globalizada;

Sabe-se que as organizações têm sido forçadas a tornarem-se mais ativas, mudando suas táticas. $\mathrm{Na}$ área do turismo/hotelaria é preciso considerar que esse processo é parte de uma conjuntura e de um processo internacional mais amplo de reestruturação, criando um contexto de novas exigências, demandas e desafios. Assim, não se concebe mais que uma organização hoteleira trate a comunicação como atividade extemporânea sem planejamento e políticas definidas. Isto ocorre em face da ausência de uma estrutura organizada de comunicação nos empreendimentos de turismo/hotelaria. Para introduzir a comunicação na estrutura organizacional dos empreendimentos de turismo/hotelaria, no entanto, faz-se necessários propósitos amplos de ação a partir, principalmente, de uma política que norteie uma estrutura de comunicação que deverá ser pautada pelo equilíbrio entre os setores da organização promovendo o enfrentamento dos problemas, estabelecendo prioridades, de forma a preservar a identidade e o conceito institucional. Entende-se que um hotel tem a função básica de propor hospitalidade, como já discutido neste trabalho, portanto, seguindo os preceitos básicos das relações públicas o relacionamento harmonioso deve começar com o público interno, que deverá ser o primeiro beneficiado das ações de relações públicas. 
Para que tudo isso comece a acontecer, entende o autor, que é preciso urgentemente que os mestres das áreas de relações públicas, turismo e hotelaria voltem seus ensinamentos para questões mais abrangentes da sociedade moderna, identificando a necessidade que o mundo organizacional tem de relacionar-se, interna e externamente. Fica como proposta, a promoção da interdisciplinaridade nos cursos de graduação de relações públicas, turismo e hotelaria, o que, com certeza daria uma nova pesquisa e um novo entendimento dos profissionais sobre estas áreas.

Desta forma, pretende-se despertar o interesse nos dirigentes de hotéis em compreender o verdadeiro papel da comunicação e a importância do relacionamento com os públicos de interesse da organização e procurar que compreendam que hoje mais que em outros tempos, os relacionamentos com os segmentos de públicos, é o instrumento que, se bem elaborado, planejado executado e avaliado, contribuirá para que o turismo e a hotelaria no Brasil consigam atingir as exigências internacionais para que este país se torne o tão desejado local hospitaleiro do turista.

Por fim, afirma-se que os hotéis da região Nordeste do Brasil, possuem e desenvolvem atividades de relações públicas de forma desordenada e, portanto, necessitam de profissionais de relações públicas com visão de estrategistas da comunicação para desenvolverem com eficiência e eficácia os relacionamentos com os seus públicos de interesse.

As reflexões aqui apresentadas representam um ponto importante na expansão no campo das atividades das relações públicas, colocando como parâmetro maior as relações sociais, por meio de práticas e políticas que afetam a organização, os espaços físicos, a integração entre os indivíduos, o turismo, a hotelaria e a hospitalidade.

Num mundo cada vez mais desafiador, composto por sociedades que se comunicam on-line e se integram cada vez mais no espaço virtual, enquanto no plano das relações humanas as distâncias aumentam a cada dia, refletir e discutir sobre temas como os aqui apresentados, faz com que se considerem questões referentes a solidariedade, cidadania, ética, responsabilidade social entre outras questões, de relevância para a sociedade.

Entende o autor ter alcançado os objetivos propostos no início desta tese. No entanto, seria muita pretensão e pura ingenuidade imaginá-la completa e definitiva. Por sua natureza aberta e constante dinâmica dos temas, relações públicas, turismo e hotelaria, permitem e requerem constantes complementações. O momento é de fertilidade para outras pesquisas e reflexões sobre o assunto. 


\section{REFERÊNCIAS BIBLIOGRÁFICAS}

Associação Brasileira da Indústria Hoteleira - ABIH. Disponível em:

<http://www.abih.com.br>, Acesso em: 05 de março de 2008.

ABREU, Vladimir Amâncio de. A máquina da hospitalidade. In: DENCKER, A. de F. M.; BUENO, M. Hospitalidade: cenários e oportunidades. Siqueira. São Paulo: Pioneira Thompson Learning, 2003.

ACERENZA, Miguel A. Administracion del turismo: conceptualización. México: Trillas, 1991.

ALDRIGUI, Mariana. Meios de hospedagem. São Paulo: Aleph, 2007.

ANDRADE, Cândido Teobaldo de Souza. Para entender relações públicas. São Paulo: Loyola, 1993.

ANDRADE, Cândido Teobaldo de Souza. Dicionário profissional de relações públicas e comunicação e glossário de termos anglo-americanos. 2 ed. São Paulo: Summus, 1996.

AMAZONAS, Eny. Histórico da hotelaria. São Paulo, 2007. Disponível em: $<$ http://www.rtaioxhotelaria.com.br/historico.php>. Acesso em: 23 fev. 2007.

BAPTISTA, Dulce M. T. O debate sobre o uso de técnicas qualitativas e quantitativas de pesquisa. In. MARTINELLI, Maria L. Pesquisa qualitativa: um instigante desafio. São Paulo: Veras, 1999.

BARRET, Richard. Libertando a alma da empresa. São Paulo: Cultrix, 1998.

BENI, Mário Carlos. Globalização do turismo: megatendências do setor e a realidade brasileira. São Paulo: Aleph, 2003.

BOFF, Leonardo. Virtudes para um outro mundo possível, Rio de Janeiro, vol. I, Vozes, 2005.

BONFATO, Antônio Carlos. Desenvolvimento de hotéis: estudos de viabilidade. São Paulo: Senac, 2006. 
BOUHDIBA, A. Massentourismus und kulturelle tradition. In: Unesco-Kurier, n.2, 1981, p. 7.

BRASIL. Lei $\mathbf{n}^{0}$ 5.377. Regulamenta a profissão de relações públicas. Brasília (DF), 11 de dezembro de 1967.

BRASIL - LDB - Lei no 9.394, Estabelece as Diretrizes e Bases da Educação Nacional. Brasília (DF), 20/12/1996.

BRUM, E.; IJUIM, J. K. Ensinar jornalismo... ou aprender jornalismo? In: PERUZZO, Cícilia M. K; SILVA, Robson B. da. Retrato do ensino em comunicação no Brasil. São Paulo: INTERCOM, 2003.

BUBER, Martin. Eu e tu. 8. Ed. São Paulo: Centauro, 2004.

BUGNICOURT, J. Sex - Sonne - Sand, Tourismus zwischen Entdeckung und Eroberung. In: Evangelischer Arbeitskreis Freizeit und Erholung. Informationen 29/30, Stuttgart, 1983, p.30.

CAILLÉ, Alain. Antropologia do dom. Petrópolis: Vozes, 2002.

CALDAS, Graça. Ensino de comunicação no Brasil: panorama e perspectivas. In: PERUZZO, C. M. K.; SILVA, R. B. da. (org). Retrato do ensino em comunicação no Brasil. São Paulo: ITERCOM, 2003.

CAMARGO, Luiz Octávio de Lima. Hospitalidade. São Paulo: Aleph, 2004.

CAMARGO, Luiz Octávio de Lima. O que é lazer. São Paulo: Brasiliense, 2008.

GUIA BRASIL 2008. São Paulo: Editora Abril, 2008.

CAMPOS, José Ruy Veloso. Estudo de viabilidade para projeto hoteleiro. Campinas, SP: Papirus, 2003.

CERVO, A. L.; BERVIAN, P. A.. Metodologia científica. São Paulo: Prentice Hall, 2002. 
CORIOLANO, Luzia Neide M. T. Do local ao global - o turismo litorâneo cearense.

Campinas, SP: Papirus, 1998.

CRISÓSTOMO, Francisco R. Turismo \& hotelaria. São Paulo: DCL, 2004.

CRUZ, Rita de Cássia A. Hospitalidade turística e fenômeno urbano no Brasil: considerações gerais. In: DIAS, Célia M. Hospitalidade: reflexões e perspectivas. Barueri, SP: Manole, 2002.

DIAS, Reinaldo. Cultura organizacional. Campinas, SP: Editoria Alínea, 2003.

DIEHL, A. A.; TATIM, D. C. Pesquisa em ciências sociais aplicadas: métodos e técnicas. São Paulo: Prentice Hall, 2004.

DUARTE, Vladir Vieira. Administração de sistemas hoteleiros: conceitos básicos. 3. ed. São Paulo: Senac, 1996.

DUMAZEDIER, Jofre. A revolução cultural do tempo livre. São Paulo: Studio Nobel/Séc, 1994.

FALCONI, Toni Muzi. Excelência nas decisões organizacionais e aceleração de sua implantação: o papel das relações públicas estratégicas. Estudos de jornalismo \& relações públicas. São Bernardo do Campo: Metodista, 2006.

FERRARI, Maria Aparecida. As dimensões locais das Relações Públicas internacionais: teorias e paradigmas. Organicom - Revista Brasileira de Comunicação Organizacional e Relações Públicas. São Paulo: USP, 2006.

FERREIRA, Aurélio Buarque de Holanda. Novo Aurélio Século XXI: o dicionário da língua portuguesa. 3. ed. Rio de Janeiro: Nova Fronteira, 1999.

FERREIRA, Waldir. Comunicação dirigida: instrumentos de relações públicas. In:

KUNSCH, Margarida Maria K. Obtendo resultados em relações públicas. 2. ed. São Paulo: Pioneira Thomson Learning, 2006.

FILHO, C. de B.; LOPES, F.; ISLER, B. Comunicação do eu: ética e solidão. Petrópolis, RJ: Vozes, 2005. 
FORTES, Waldyr Gutierrez. Relações públicas - processos, funções, tecnologia e estratégias. 2. ed. São Paulo: Summus, 2003.

FRANÇA, Fábio. Relações públicas: estratégia de relacionamentos com públicos específicos. 2002. Tese (Doutorado)- Programa de Pós-Graduação em Ciências da Comunicação. Escola de Comunicações e Artes da Universidade de São Paulo. São Paulo, 2002.

Yendis, 2004.

Públicos: como identifica-los em uma visão estratégica. São Caetano do Sul, SP:

Relações públicas no século XXI: relacionamento com pessoas. In: KUNSCH,

Margarida Maria K. Obtendo resultados em relações públicas. 2. ed. São Paulo: Pioneira Thomson Learning, 2006.

FREITAS, R. F.; SANTOS, L. L. dos. Desafios contemporâneos em comunicação: perspectivas de relações públicas. São Paulo: Summus, 2002.

FREITAS, S. G.; FRANÇA, F. Manual de qualidade em projetos de comunicação. São Paulo: Pioneira, 1997.

GASKELL, G.; BAUER, M. W. Pesquisa qualitativa com texto, imagem e som. Petrópolis: Vozes, 2002.

GIDRA, G; DIAS, C. M. de M. Hospitalidade da simplicidade à complexidade. In: DENKER, Ada de Freitas. Planejamento e gestão em turismo e hospitalidade. São Paulo: Pioneira Thomson Learning, 2004.

GOTMAN, Anne. Le sens de l'hospitalité: essai sur les fondements sociaux de l'accueil de l'autre. Paris: Presses Universitaires de France, 2001.

GREENHALGH, Leonard. Relacionamentos estratégicos - a chave para o sucesso dos negócios. São Paulo: Negócio, 2002.

GRINOVER, Lúcio. Hospitalidade: um tema a ser reestudado e pesquisado. In: DIAS, Célia M. de Moraes. Hospitalidade: reflexões e perspectivas. Barueri, SP: Manole, 2002.

GRINOVER, Lúcio. A hospitalidade, a cidade e o turismo. São Paulo: Aleph, 2007. 
HOWART \& HOWART, (UK). Hotels of the future. Strategies and action plan. International Hotel Association: Paris, 2005.

IANHEZ, João Alberto. Relações públicas nas organizações. In: KUNSCH, Margarida Maria K. Obtendo resultados em relações públicas. 2. ed. São Paulo: Pioneira Thomson Learning, 2006.

IANNI, Otávio. Teorias da Globalização. Rio de Janeiro: Civilização Brasileira, 1995.

Enigmas da modernidade-mundo. Rio de Janeiro: Civilização Brasileira, 2000.

KLEIN, Otto. Organização hoteleira. Caxias do Sul: Educs, 1980.

KRIPPENDORF, Jost. Sociologia do turismo: para uma nova compreensão do lazer e das viagens. São Paulo: Aleph, 2001.

KUNSCH, Margarida Maria K. Planejamento de relações públicas na comunicação integrada. 4. ed. São Paulo: Summus, 2003.

Obtendo resultados com relações públicas. 2. ed. São Paulo: Pioneira Thomson Learning, 2006.

LASHLEY, C; MORISON, A. Em busca da hospitalidade: perspectives para um mundo globalizado. Barueri, SP: Manole, 2004.

LAUS, Regina. Governança. In: CIRILO, Lecy. Administração hoteleira: desafios e tendências. São Paulo: DVS, 2006.

LEMOS, Leandro de. O valor turístico: (re) definindo a economia do turismo. In: Barreto, M.; REJOWSKI, M. Turismo: interfaces, desafios e incertezas. Caxias do Sul: Educs, 2001.

LESLY, Philip (coord.). Os fundamentos de relações públicas e da comunicação. Tradução Roger Cahen. São Paulo: Pioneira, 1995.

LIPOVETSKY, Gilles. Os tempos hipermodernos. São Paulo: Barcarolla, 2004. 
MARCHIORI, Marlene Regina. Mudança cultural e a responsabilidade das relações públicas. Org. Revista Brasileira de Comunicação Organizacional e Relações Públicas. São Paulo: USP, 2004.

MARCHIORI, Marlene. Org. Faces da cultura e da comunicação organizacional. São Caetano do Sul, SP: Difusão Cultural, 2006.

MARCONI, M. de A.; LAKATOS, E. M. de. Técnicas de pesquisa: planejamento e execução de pesquisas, amostragens e técnicas de pesquisas, elaboração, análise e interpretação de dados. 5. ed. São Paulo: Atlas, 2002.

MARQUES, J. Albano. Introdução à hotelaria. Bauru, SP: EDUSC, 2003.

MARTINS, Maria Terezinha Motta Campos. Relações Públicas na era da informação: abordagens das mídias audiovisuais e digitais em cursos superiores. 2003. Tese. (Doutorado). Programa de Pós-Graduação em Ciências da Comunicação. Escola de Comunicações e Artes da Universidade de São Paulo. São Paulo, 2003.

MATIAS, Marlene. Turismo formação profissionalização. Barueri: Manole, 2002.

MEDLIK, S.; INGRAM, H. Introdução à hotelaria: gerenciamento e serviços. Rio de Janeiro: Campus, 2002.

MEIRELES, Cecília. Crônicas de viagem, 3. Rio de Janeiro: Nova Fronteira, 1999.

MENESCAL, L. C. de A.; GONÇALVES, M. H. B. Introdução a turismo e hotelaria. Rio de Janeiro: Senac Nacional, 2006.

MOLERO, Miguel. Alcunas claves de turismo.Madri: Insade, 1974.

MONTANA, P. J; CHARNOV, B. H.; Administração. São Paulo: Saraiva, 1998.

MONTANDON, Alain. Hospitalidade ontem e hoje. In: DENCKER, A. de F. M.; BUENO, M. S. Hospitalidade: cenários e oportunidades. São Paulo: Pioneira Thompson Learning, 2003.

MORA, José Ferrater. Dicionário de filosofia. São Paulo: Loyola, 2000. 
MORAES, Irany Nova. Perfil da universidade. São Paulo: Pioneira, 1986.

MORIN, Edgar. As duas globalizações: complexidade e comunicação, uma pedagogia do presente. 3. ed. Porto Alegre: Sulina, 2007.

MORGAN, Garret. Imagens da organização. São Paulo: Atlas, 1996.

NASSAR, Paulo. Relações públicas na construção da responsabilidade histórica e no resgate da memória institucional das organizações. São Caetano do Sul, SP: Difusão, 2007.

NETO, A. P.; TRIGO, L. G. de G. Reflexões sobre um novo turismo: política, ciências e sociedade. São Paulo: Aleph, 2003.

NIELSEN, Christian. Turismo e mídia: construção e destruição de destinos turísticos. São Paulo: Contexto, 2002.

OLIVEIRA, M. J. da C.; NADER, S. Relações Públicas na gestão da responsabilidade social: desafio e oportunidade. Organicom - Revista Brasileira de Comunicação Organizacional e Relações Públicas. São Paulo: USP, 2006.

Organização Mundial do Turismo - OMT Disponível em: <http://www.world-tourism .org>, Acessado em: 10 abr. 2008.

PAULA, Nilma Morcerf. Planejamento e gestão da hospitalidade em restaurantes. In: DENKER, A. de F. M.. Planejamento e gestão em turismo. São Paulo: Pioneira Thomson Learning, 2004.

PEREIRA, Julio C. R. Análise de dados qualitativos - estratégias metodológicas para as ciências da saúde, humanas e sociais. São Paulo: Universidade de são Paulo, 2004.

PERUZZO, Cicília Maria Kroling. Observação participante e pesquisa-ação. In: DUARTE, J.; BARROS, A. (Org.). Métodos e técnicas de pesquisa em comunicação. São Paulo: Atlas, 2005.

PETROCCHI, Mário. Hotelaria: planejamento e gestão. São Paulo: Pearson Prentice Hall, 2007. 
RIBEIRO, Darcy. A universidade necessária. 5.ed. Rio de Janeiro, Paz e Terra, 1991.

RICCI, Renato. Hotel estratégias competitivas: um guia prático para a aplicação da gestão de processos e do balanced scorecard no segmento da hotelaria e do turismo. Rio de Janeiro: Qualitymark, 2005.

ROSE, Alexandre T. de. Turismo: planejamento e marketing. Barueri, SP: Manole, 2002.

SCHUCH, Carlos Honorato. Desempenho da cadeia produtiva na indústria do turismo. In: BARRETO; MARGARITA; REJOWSKI, M. Turismo: interfaces, desafios e incertezas. Caxias do Sul: Educs, 2001.

SCHULUTER, Metodologia da pesquisa em turismo e hotelaria. São Paulo: Aleph, 2003.

SELWYN, Tom. Uma antropologia da hospitalidade. In: LASHLEY, C.; MORRISON, A. Em busca da Hospitalidade: perspectivas para um mundo teórico. São Paulo: Manole, 2004.

SÊNECA. As relações humanas: a amizade, os livros, a filosofia, o sábio e a atitude perante a morte. Tradução, Renata Maria Parreira Cordeiro. 2.ed. São Paulo: Landy, 2007.

SIMÕES, Roberto Porto. Relações públicas: função política. 5.ed. São Paulo: Summus, 1995.

Relações públicas e micropolítica. São Paulo: Summus, 2001.

SIMON, Raymond. Relações públicas: teoria y prática. México: Limura/Noriega, 1994.

SOUSA, Jorge Pedro. Planificando a comunicação em relações públicas. Florianópolis, SC: Secco, 2004.

SOUZA, A. M.; CORREA, M. V. M. Turismo - conceitos, definições e siglas. 2.ed. Manaus: Valer, 2000.

SROUR, Robert. Poder, cultura e ética nas organizações. [S.1.]: Campus, 1998.

STUMPF, Ida Regina C. Pesquisa bibliográfica. In: DUARTE, J.; BARROS, A. (Org.). Métodos e técnicas de pesquisa em comunicação, São Paulo: Atlas, 2005. 
TRIGO, L. G. de G.; NETO, A. P. Reflexões sobre um novo turismo: política, ciências e sociedade. São Paulo: Aleph, 2003.

VERSIC, D.; GRUNIG, L.; GRUNIG, J. Global and specific principles of public relations: evidenc fron slovenia. In: CULBERTSON, H.; CHEN, N. (orgs.) International public relation a comparative analysis. Mahwah: Erlbaum, 1996.

WADA, Elizabeth K. Reflexões de uma aprendiz de hospitalidade. In: DENCKER, A. de F. M.; BUENO, M. S.. Hospitalidade: cenários e oportunidades. São Paulo: Pioneira Thompson Learning, 2003.

WEBER, Erick J. El problema del tiempo libre, estúdio antropológico e pedagógico. Madri: Nacional, 1969.

WEY, Ana Maria. Hotéis e hóspedes do novo milênio. Disponível em: <http://www.abih.com.br> Acesso em: 30 outubro 2001.

ZUBEN, Newton Aquiles van. Apud. BUBER, Martin. Eu e tu. 8.ed. São Caetano, SP: Centauro, 2004. 


\section{APÊNDICES}


APÊNDICE A - MODELO DE PROTOCOLO

\begin{tabular}{|l|l|}
\hline Hotel & \\
\hline Classificação - Guia 4 rodas & \\
\hline Endereço & \\
\hline Responsável pelas informações & \\
\hline Função & \\
\hline Formação & \\
\hline Tempo na função & \\
\hline Setor de comunicação/nomenclatura & \\
\hline Outras informações & \\
\hline
\end{tabular}

\section{PESQUISA}

Pesquisas com hóspedes

Pesquisa com funcionários

Pesquisas na comunidade

Identificação dos públicos

Situações que afetam a imagem/conceito do hotel

Outras atividades relacionadas à pesquisa

\section{ASSESSORIA}

Políticas de relações públicas

Políticas de apoio ao marketing

Políticas de propaganda institucional

Sugestões de mudanças de atitude na forma de tratar com os setores de opinião pública

Outras atividades relacionadas à assessoria

\section{PLANEJAMENTO}

Elaboração de Planejamento Estratégico de Comunicação para o hotel

Elaboração de planos, campanhas e ações de Relações Públicas.

Planejamento de Campanhas Institucionais 


\section{EXECUÇÃO}

Publicações para empregados

Publicações para hóspedes

Site

Visitas ao Hotel

Cadastro da Imprensa

Cadastro de hóspedes

Cadastro de autoridades locais

Cadastro de entidades da área de turismo/hotelaria

Publicações para operadoras/agências de viagens

\section{Eventos}

1 - salas

2 - organização

Eventos especiais

Quadros de avisos

Mural

Intranet

Arquivos de áudio

Arquivos de fotos

Arquivo de imagem

Outras atividades

\section{AVALIAÇÃo}

Avaliação dos programas de comunicação

Formas de avaliação

Outras informações sobre avaliação 
APÊNDICE B - HOTÉIS PESQUISADOS

\section{CEARÁ}

Ponta Mar

Oásis Atlântico Hotels e Resorts

Marina Park Hotel

\section{ALAGOAS}

Ponta Verde Praia

Mar Hotel Maceió

Jatiúca Resort

Maceió Atlantic Suites

\section{PARAÍBA}

Tropical Tambau

Hardman Praia

Caiçara

Village João Pessoa

\section{PERNAMBUCO}

Recife Monte

Cannarius

Recife Palace

Mar Hotel Recife

Internacional Palace Hotel-Recife 


\section{RIO GRANDE DO NORTE}

Pestana Beach Resort Parque D Costeira Ltda

Serhs Grande Hotel

Ocean Grande Hotel Natal

\section{MARANHÃO}

Best Western Praia Mar Hotel

Brisamar

Rio Poty

\section{SERGIPE}

Parque dos Coqueiros

Quality

Starfish Ilha de Santa Luzia

Celi Hotel Aracaju

\section{BAHIA}

Vila Gale Salvador

Blue Tree Towers

Mercury Salvador Accor

Pestana Convento do Carmo 